\title{
A Ten-Year Evaluation of Structural and Compositional Development In Unmanaged Central Appalachian Clearcuts
}

Jonathan R. Marden

West Virginia University

Follow this and additional works at: https://researchrepository.wvu.edu/etd

\section{Recommended Citation}

Marden, Jonathan R., "A Ten-Year Evaluation of Structural and Compositional Development In Unmanaged Central Appalachian Clearcuts" (2010). Graduate Theses, Dissertations, and Problem Reports. 4630.

https://researchrepository.wvu.edu/etd/4630

This Thesis is protected by copyright and/or related rights. It has been brought to you by the The Research Repository @ WVU with permission from the rights-holder(s). You are free to use this Thesis in any way that is permitted by the copyright and related rights legislation that applies to your use. For other uses you must obtain permission from the rights-holder(s) directly, unless additional rights are indicated by a Creative Commons license in the record and/ or on the work itself. This Thesis has been accepted for inclusion in WVU Graduate Theses, Dissertations, and Problem Reports collection by an authorized administrator of The Research Repository @ WVU. For more information, please contact researchrepository@mail.wvu.edu. 


\section{A Ten-Year Evaluation of Structural and Compositional Development In Unmanaged Central Appalachian Clearcuts}

\section{Jonathan R. Marden}

Thesis submitted to the Davis College of Agriculture, Natural Resources and Design at West Virginia University in partial fulfillment of the requirements

for the degree of

Master of Science

in

Forestry

Eric Heitzman, Ph.D., Committee Chair

Gary Miller, Ph.D.

James Rentch, Ph.D.

John R. Brooks, Ph.D.

Division of Forestry and Natural Resources

Morgantown, West Virginia

2010

Keywords: Age Classes, Aspect, Central Appalachians, Cheat Ranger District, Clearcuts, Even Age Silviculture, Regeneration, Wild Grapevines 


\title{
ABSTRACT \\ A Ten-Year Evaluation of Structural and Compositional Development In Unmanaged Central Appalachian Clearcuts
}

\author{
Jonathan R. Marden
}

The varied growing conditions, fractured topography, and diversity of woody species in the Central Appalachians ensure that the harvest response of forest stands in the region will never be easily predictable. Clearcutting exposes the seedbed and freshly cut stumps of a harvested forest to full sunlight, encouraging the regeneration of the greatest number of species possible for that region. Gathering information on stand response to a complete removal in the mixed mesophytic forests of West Virginia will add valuable information to the silvicultural database for the most complex hardwood ecosystem in North America.

Beginning in 1998, U.S. Forest Service personnel installed permanent plots in the Cheat Ranger District of the Monongahela National Forest and began recording observations of early growth response in over 90 even age stands. Utilizing a subset of that initial data, and data from subsequent inventories in 2004 and 2009, this project evaluated the 10 year development of 15 of those clearcuts. This study answers the question of how these even age forests changed over time, without stand management.

Results demonstrated the diverse regeneration of over 40 woody species following clearcutting. Yellow-poplar and oaks were the dominant species in the overstory. Yellowpoplar was more important on mesic and southerly aspects, and oak dominated the xeric aspects. Significant increases in basal area/acre, coinciding with significant decreases in tree density, were sustained in stands of up to 30 years of age. Best basal area growth occurred on southerly stands, followed by summit and westerly stands. Poorest basal area development was exhibited by mesic sites, where wild grapevines had an adverse effect. Grapevines were established on 11 of 15 stands in 2009. Only statistically non-significant changes in grapevine levels were exhibited over the study period in all stands combined. This indicated that vine establishment occurs early in stand development, between harvest and canopy closure. Grapevine damage was more severe on mesic aspects than on southerly and westerly aspects, and summits. 


\section{ACKNOWLEDGEMENTS}

I would like to thank my advisor, Dr. Eric Heitzman for his support and counsel throughout this process. I would also like to thank my committee members Dr. John Brooks, Dr. Gary Miller, and Dr. James Rentch for additional and invaluable assistance. I would not have reached this point without the help I have received from all of you. I would like to thank the West Virginia University Division of Forestry and Natural Resources for the opportunity to study in their program.

I would like to thank Brian Simpson at the Northern Research Station of the U. S. D. A. Forest Service, in Morgantown. His help in providing maps, plot coordinates, assistance in the field, and a variety of other information made it possible for me to complete the project fieldwork. Thanks to John Juracko for project inventory assistance, and to personnel at the Cheat Ranger District Office in Parsons, West Virginia for providing me with keys for access to Forest Service roads. Thanks to Dr. Phil Turk for occasional technical assistance, and feedback on my presentation.

I would like to thank my parents Parker and Ann Marden for their interest in, and unconditional support of my endeavors, as well as my sister Kerri Ann, whose continued encouragement and familiarity with the graduate experience helped keep me focused on my goal. 


\section{TABLE OF CONTENTS}

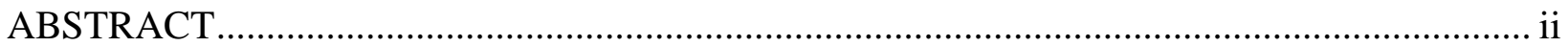

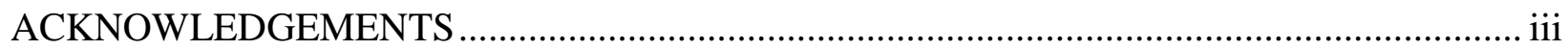

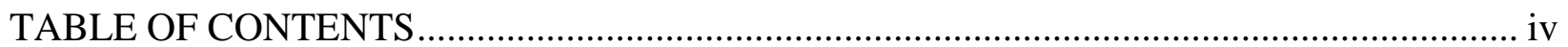

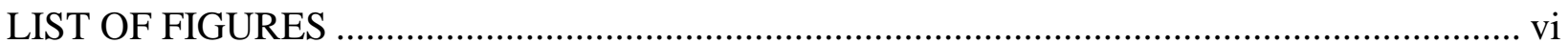

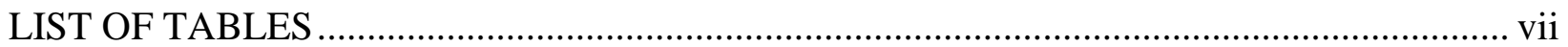

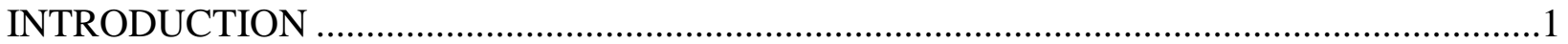

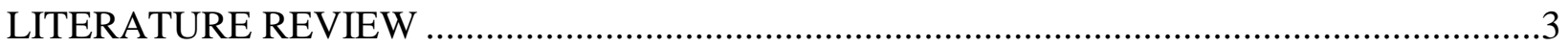

The History of Clearcutting on the Monongahela National Forest..........................3

Observations from Clearcut Studies on the Monongahela National Forest.............6

The Influence of Wild Grapevines in the Central Appalachians ..........................10

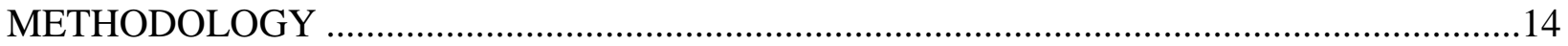

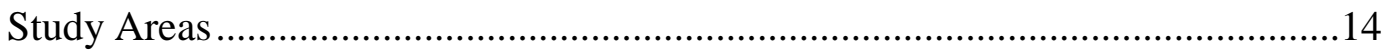

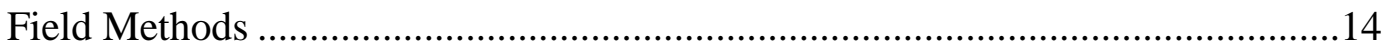

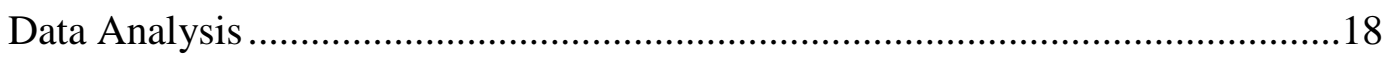

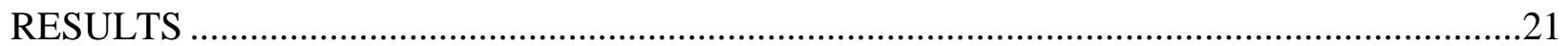

All Stands Combined ...................................................................................21

Stand Development by Age Class................................................................26

Stand Development by Aspect..........................................................................33

Wild Grapevine Effects on Stand Development................................................38 
DISCUSSION

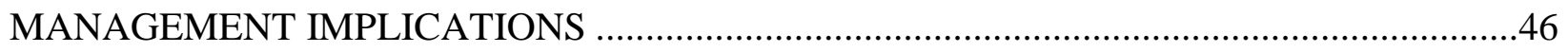

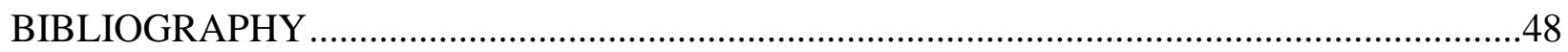

APPENDIX: Plot photographs in 2009 capturing up-slope, down-slope, lateral, and canopy views. Series includes five plots for each aspect ...................................................52 


\section{LIST OF FIGURES}

Figure 1. Locations of the 15 clearcut stands in the study area ..................................................15

Figure 2. Plot photographs capturing up-slope, down-slope, lateral, and canopy views

Figure 3. Changes in mean basal area per acre for 15 clearcut stands in West Virginia from 1999-2009. Includes all trees $\geq 1$ inch dbh and overstory trees (dominants and codominants). Vertical lines above the means represent standard errors. A change in alphabetical notations indicates a significant difference between means over time $(\mathrm{P} \leq 0.05)$.

Figure 4. Changes in mean stand density for 15 clearcut stands in West Virginia from 19992009. Includes all trees $\geq 1$ inch dbh and overstory trees (dominants and codominants). Vertical lines above the means represent standard errors. A change in alphabetical notations indicates a significant difference between means over time $(\mathrm{P} \leq 0.05)$

Figure 5. Changes in mean height of codominant trees on 15 clearcut stands in West Virginia from 1999-2009. Vertical lines above the means represent standard errors. A change in alphabetical notations indicates a significant difference between means $(\mathrm{P} \leq 0.05) ; \mathrm{n}=195$

Figure 6. Changes in mean basal area per acre by age class for trees $\geq 1$ inch dbh on 15 clearcut stands in West Virginia from 1999-2009. Vertical lines above the means represent standard errors. A change in the alphabetical notations indicates a significant difference between means over time $(\mathrm{P} \leq 0.05)$

Figure 7. Changes in mean stand density by age class for trees $\geq 1$ inch dbh on 15 clearcut stands in West Virginia from 1999-2009. Vertical lines above the means represent standard errors. A change in the alphabetical notations indicates a significant difference between means over time $(\mathrm{P} \leq 0.05)$

Figure 8. Distribution and relative severity of overstory grapevine infestation for all infested clearcut stands from 1999-2009. No significant differences exist between measurements $(\alpha=0.05)$

Figure 9. Distribution and relative severity of overstory grapevine infestations among slope aspects in 2009. A change in alphabetical notations indicates a significant difference between infestation levels $(\mathrm{P} \leq 0.05)$ 


\section{LIST OF TABLES}

Table 1. Changes in percent basal area of overstory trees (dominants and codominants) on 15 clearcut stands in West Virginia from 1999-2009. P-values are included where $\mathrm{P} \leq 0.05 ; \mathrm{n}=195$.

Table 2. Changes in stand density of overstory trees (dominants and codominants) on 15 clearcut stands in West Virginia form 1999-2009. P-values are included where $\mathrm{P} \leq 0.05$; $\mathrm{n}=195 .$.

Table 3. Changes in percent basal area of overstory trees (dominants and codominants) by age class on 15 clearcut stands in West Virginia from 1999-2009. P-values are included where $\mathrm{P} \leq$ 0.05 .

Table 4. Changes in stand density of overstory trees (dominants and codominants) by age class on 15 clearcut stands in West Virginia from 1999-2009. P-values are included where $\mathrm{P} \leq 0.05$.

Table 5. Changes in mean basal area per acre by aspect for all trees $\geq 1$ inch dbh on 15 clearcut stands in West Virginia from 1999-2009. P-values are included where $\mathrm{P} \leq 0.05 \ldots$

Table 6. Changes in stand density by aspect for trees $\geq 1$ inch dbh on 15 stands in West Virginia from 1999-2009. P-values are included where $\mathrm{P} \leq 0.05$.

Table 7. Changes in percent basal area of overstory trees (dominants and codominants) by aspect on 15 clearcut stands in West Virginia from 1999-2009. P-values are included where $\mathrm{P} \leq$ 0.05 .

Table 8. Changes in stand density of overstory trees (dominants and codominants) by aspect on 15 clearcut stands in West Virginia from 1999-2009. P-values are included where $\mathrm{P} \leq 0.05$. 


\section{INTRODUCTION}

Clearcutting is a practice that was particularly widespread on the Monongahela National Forest during the time period spanning from 1964 to 1990. During that time, over 1200 stands were harvested over an area encompassing approximately 30,000 acres. It has become a forest management version of a "Catch-22". On one hand it is an effective means of initiating a new forest in a region where the land has the inherent capacity for natural regeneration. On the other hand, it is a conspicuous harvest method resulting in a temporary barren landscape vista that quickly draws public opposition. Over the last thirty years emphasis has been focused on finding alternatives to clearcutting, in order to avoid the widespread negative public reaction to it.

U.S.D.A. Forest Service Study 68 has served as a platform for multiple projects and was initiated by the Northern Research Station of the USDA Forest Service, in Morgantown, West Virginia. Forest Service personnel installed permanent plots in 1998 and began recording observations of early growth response in over 90 clearcut stands. Over the 25-year time period during which harvests were performed, stands have regenerated that are now at different stages of maturity.

This project is part of U.S.D.A. Forest Service Study 68 and focuses on the development of 15 unmanaged clearcut stands from 1999-2009. In 2009 the stands ranged in age from 19 to 39 years, and occupied all slope aspects. Their diversity provides an opportunity to observe and compare ten years of structural and compositional development at different levels of maturity and in varied growing conditions. The objective of this study is: 1) to describe stand level changes in structure and species composition from 1999-2009, and 2) to contribute information 
on how age and aspect affect regeneration response of Central Appalachian stands to clearcutting in the absence of intermediate silvicultural treatments. 


\section{LITERATURE REVIEW}

\section{The History of Clearcutting on the Monongahela National Forest}

The establishment of the Monongahela National Forest (MNF) in 1915 was the culmination of four successive legislative acts by Congress taken to protect the watersheds of navigable streams (Shands 1992). The response directly followed a period in time spanning the late 1800 's to early 1900's in which eastern forests were excessively harvested. In the aftermath of being completely logged out in some areas, extensive erosion and sedimentation resulted from sudden loss of vegetation. This problem was exacerbated by large scale fires fueled by residual logging slash (Hicks 1997). Further fallout resulted in the form of devastating floods, a corollary of the reduction in vegetation (McKim 1970). The cumulative effect of the logging and fires during this period had a wide-scale, landscape-altering effect that imposed a considerable threat to the health of watersheds (Berman et al. 1992).

The widespread confluence of events threatening ecosystem health was the impetus for the formation of the U.S. Forest Service in 1905 (Williams 2007). Congress was further compelled in 1908 to allocate money to identify watersheds in greatest need of protection. This was followed by the Weeks Act of 1911, which authorized the purchase of those lands for long term protection and natural resource management. Shortly following the passage of the Weeks Act, the first land purchased in West Virginia was the 7,200 acre Arnold tract in Tucker County (McKim 1970). The Weeks Act was followed in 1915 by “The Monongahela Purchase”, which was essentially the unofficial establishment of the MNF (Berman et al. 1992). Finally, on April 28, 1920 the Monongahela Purchase was declared a National Forest. Today the MNF covers 
919,000 acres, and is the fourth largest National Forest in the northeastern United States

(U.S.D.A. Forest Service. Monongahela National Forest. Online Citation).

With results of the wide-scale natural resource exploitation still evident, new alternatives to high-impact harvesting were implemented through the 1950's on U.S. Forest Service land. The approach widely settled upon was selection cutting, an environmentally softer approach that imposed a more subtle change in forest appearance (Berman et al. 1992). Selection cutting reflected the new rationale of forest management in what was referred to as "the custodial era" of the U.S. Forest Service (Williams 2007). Unfortunately, with the passage of time, selection cutting in eastern forests resulted in the reduction of tree species diversity, as well as timber stand quality (Della Bianca and Beck 1985). The smaller openings created by selection harvests favored the regeneration of a greater percentage of shade tolerant trees (Lamson and Smith 1991), displacing several commercially desirable intolerant species (Dale et al. 1994). Stand quality also suffered due to the poor logging practice of high grading wherein only the best timber trees are removed, and the poorest, least valuable genetic stock is left behind to initiate future growth. Hence, by the 1960’s, a combination of excessive and improper use of selection cutting had resulted in many poor quality, second growth forest stands in need of recovery (Berman et al. 1992).

In 1964 the U.S. Forest Service made an internal decision to change its method of harvesting from selection cutting to even age management (Conrad 1997). This change was made largely without public awareness or approval, and was a combined response to increasingly homogenous forests managed solely with selection cutting, coinciding with increasing economic demand for forest products (Steelman 2007). In the early 1970's, a controversy in West Virginia transpired in response to some large and conspicuous even age harvests. Clearcuts of 600 and 
400 acres had been performed in the region of the Cranberry Backcountry, as well as an 800 acre clearcut harvest near Richwood, West Virginia (Steelman 2007). In addition, nearby stands that had been recently harvested using the selection system had been re-entered for complete overstory removals. The public at large envisioned a second coming of the exploitative logging at the turn of the century (Berman et al. 1992).

During this period, one of the most notable challenges facing the Forest Service was in the wording of the Organic Act of 1897 (Open Jurist. United States Court of Appeals. Online citation). This was legislated before the Forest Service was in existence and before the advent of modern forestry. It stated that in the interest of preserving living and growing timber, and to promote young growth on national forests, only the dead, weakest or most mature trees shall be cut, and that timber shall be marked and removed only under the supervision of an individual appointed by the Secretary of Agriculture (Fairfax and Achterman 1977). In West Virginia, the Organic Act became the basis for a high profile civil action suit in 1972, brought against the Forest Service by the Izaak Walton League (Staff Writer 1976). The courts upheld the lawsuit, known as “The Monongahela Decision”, and new restrictive timber management guidelines were imposed (Steelman and Ascher 1997). The provisions mandated by Congress resembled those of the original Organic Act in that only mature trees could be cut. Since few mature hardwoods had been left over from the turn of the century logging, and even fewer still remained after more recent harvests, the Forest Service had few options available to supply timber demand (Conrad 1997).

Even after the Monongahela Decision, clearcutting by the Forest Service was continued so that timber harvest contracts established prior to litigation would be fulfilled (Berman et al. 1992). This further agitated a now vigilant public, and resulted in additional but less 
sensationalized civil protests. Congress responded by passing the Forest and Rangeland Renewable Resources Planning Act of 1974, and its amendment, the National Forest Management Act (NFMA), in 1976 (Williams 2007). These replaced much of the wording of the Organic Act, and did not completely exclude clearcutting. Among their provisions were an emphasis on reducing clearcut sizes, shaping harvested areas to be more pleasing to the eye, and conducting extensive research on alternative harvesting methods such as variants of partial cutting, group selection, and selection cutting (Dale et al. 1994; Conrad 1997).

\section{Observations from Clearcut Studies on the Monongahela National Forest}

A lesson had been learned that choosing one harvest technique to meet all objectives was an unacceptable approach. As a result, clearcutting was not altogether abandoned following the legislation of the National Forest Management Act (Berman et al. 1992). Smaller opening sizes stood to generate less controversy, and so a new area of interest focused on the extent to which clearcut opening size could be reduced without compromising the characteristic benefits of species diversity (Smith 1981).

To determine a functional minimum clearcut diameter, individuals at the U.S. Forest Service performed a study in the Fernow Experimental Forest (FEF) in which regeneration was sampled in cleared openings of various sizes, on stands with oak site indexes of 60 and 75 (fair and good quality) (Trimble 1973). The goal was to identify the minimum opening size that would enhance species diversity and timber quality normally associated with larger clearcuts (Smith 1981). Conversely, an opening too small would be too greatly influenced by the shading effect of the surrounding forest (Dale et al. 1994). Results demonstrated that openings $\geq 150$ feet in diameter had more quality codominant stems with greater average diameters than the smaller 
openings. Species composition varied by opening size. The larger openings contained dominant species including oaks (Quercus sp.), yellow-poplar (Liriodendron tulipifera L.), black cherry (Prunus serotina Ehrh.), and black birch (Betula lenta L.). Smaller openings contained oak, red maple (Acer rubrum L.), sugar maple (Acer saccharum Marsh.), striped maple (Acer pensylvanicum L.), and American beech (Fagus grandifolia Ehrh.) (Miller and Kochenderfer 1998). Whereas the larger openings averaged 12 tree species, the smaller openings contained an average of 3 species.

Also on the FEF, Trimble and Hart (1961) conducted a study on forest reproduction to answer questions about regeneration response following harvests of varying intensities. Cutting intensities ranged from clearcutting to light high grading, and were performed on hardwood sites of site index 60 (fair), 70 (good), and 80 (excellent) (Trimble 1973). Temporary plots were inventoried before logging and twice more after harvests at five year intervals. Abundance, distribution, and species composition of reproduction were measured. Two classes of regeneration were recorded: "small reproduction" 1 foot tall to 1 " dbh, and "large reproduction" 1- 5" dbh (Wendell and Trimble 1968). Only commercial species were included.

Prior to harvest, on good and excellent sites, sugar maple accounted for 30 - 50\% of the reproduction in both classes. Beech ranked second in both reproduction classes. On fair sites, the small reproduction was dominated by sassafras (Sassafras albidum (Nutt.) Nees), and chestnut oak (Quercus prinus L.), while sugar and red maple dominated the large reproduction class. Five years after harvest the clearcuts filled in with the highest numbers of reproduction, with over 10,000 stems per acre of small reproduction, and over 450 stems of large reproduction. There were also a higher percentage of stems of sprout origin (55\%). Species composition on the clearcuts was dominated by yellow-poplar on excellent sites, while northern red oak was present 
on good sites. Black cherry was found on sites of all quality and cutting intensities, but was most numerous in clearcuts. Black locust (Robinia pseudoacacia L.) was well represented in the large reproduction class on the clearcut sites, because it develops rapidly from root sprouts (Burns and Honkala 1990). Sugar maple was abundant on sites of all quality and cutting intensities.

Ten years after harvest, overstory competition consumed available growing space, and hindered extensive development of new small reproduction (Trimble 1972). Dense growth of staghorn sumac (Rhus typhina L.), and pin cherry (Prunus pensylvanica L.f.) saplings had joined the sapling stems of desirable species present in the 5-year inventory. The most abundant species for small regeneration 10 years after harvest was sugar maple (45\%), followed by yellow-poplar (19\%). Large reproduction was dominated by black locust (30\%), sugar maple (23\%), and yellow-poplar (15\%).

In another clearcut study conducted on the FEF, Brashears et al. (2004) investigated changes in species richness on 13 high quality third growth clearcuts. The clearcuts were separated into three age classes: those aged 2-6 years, 12-16 years, and 22-26 years. Species richness and diversity were calculated with the use of Pielou's evenness index, species richness, and the Shannon-Weiner diversity index $(\mathrm{H})$. Pielou's index is the measure of consistency of species abundance (Mountford 1961). Species richness is the number of species occupying each stand. The Shannon-Weiner index incorporates importance values [IV = (species relative density + species relative basal area)/2], species richness, and Pielou’s Index.

Prior to each harvest, all trees $>5$ in dbh were inventoried according to species, dbh, origin, and canopy strata. Pre-harvest second growth stands contained equal percentages of sugar maple and yellow-poplar in the canopy, while the post harvest clearcuts contained 43\% 
yellow-poplar and 13\% sugar maple. Moreover, as yellow-poplar increased in importance over time, species such as American beech, black birch, hickories, and oaks showed a waning presence. While species richness was sustained in stands in all age groups, species diversity and evenness decreased significantly over time (Brashears et al. 2004). These results were similar to those found by Schuler and Gillespie (2000) in another third growth, even age study on the FEF in which stands were evaluated for species richness.

In another clearcut study on the FEF, Gilliam et al. (1995) utilized the Shannon-Weiner index to compare the species diversity of two 20 year old clearcut stands and two mature 70year-old selectively cut stands. Their results indicated that the young clearcuts possessed slightly greater woody overstory species richness than the selectively cut mature stands. On a per plot basis, clearcuts averaged $>7$ species per plot, with over $70 \%$ of the plots having more than 8 species. Meanwhile, selectively cut stands averaged 6 species per plot, but $60 \%$ of plots averaged less than that.

Despite the overall differences in species richness, presence of the four most prominent species in the study was noted in all stands, regardless of harvest method or age (Gilliam et al. 1995). These species included sugar maple, yellow-poplar, black cherry, and northern red oak (Quercus rubra L.). Importance values (IV = relative density + relative basal area) for each species varied with stand age. Further results indicated as stands age, shade intolerant species such as yellow-poplar, black cherry, and black locust were replaced by more shade tolerant species such as sugar maple, red oak, and American beech.

In preliminary observations of stand response to clearcutting by Miller et al. (2001), 
young clearcuts on the MNF had succeeded in regenerating a wide variety of woody and herbaceous plant species. The species composition of 26 young clearcut stands was compared to the overstory composition of 19 adjacent mature stands. Generally, dominant overstory species in the mature stands also dominated the overstories of the young clearcuts (Miller et al. 2001). However, there were also some notable shifts in species composition. For example, red oak and black cherry occupied the majority of basal area in the overstories of the mature stands, while some young clearcuts were dominated by sugar and red maple. In other clearcuts, the proportion of yellow-poplar and black cherry was higher than it was in the mature stands. On still other young stands, the expected proportion of red and chestnut oaks was reduced, as they were partially displaced by black cherry and yellow-poplar (Miller et al. 2001).

Several factors could have contributed to the aforementioned species shifts observed in the clearcut stands. Among influential factors are seedbed condition, availability of stored seed, advance regeneration at the time of harvest, timing of the harvest, wildlife herbivory, insects and diseases, severity of fires, and site quality limitations (Smith et al. 1997; Miller et al. 2001; Brashears et al. 2004;). It is not surprising that these shifts occurred, particularly with regard to the position of oaks in the overstory. The regeneration of the second growth stands was preceded by fire, while this was not part of the disturbance regime inducing the latest growth. In addition, regeneration in the young clearcut stands was subject to higher levels of deer browsing (Miller et al. 2001).

\section{The Influence of Wild Grapevines in the Central Appalachians}

Following a clearcut harvest, there are two native grapevine variants known in the Central Appalachians that usually grow with stands as they develop: Vitis aestivalis Michx. 
(summer grape), and Vitis aestivalis var. argentifolia Fernald, formerly var. bicolor Deam (silverleaf or blueleaf grape) (Carey 1994). Vines secure themselves with tendrils to low growing stems and twigs of seedlings that are within their reach, and travel upward with the host tree as it grows. A grapevine in the crown of an 80 year old tree is apt to be 80 years old (Trimble and Tryon 1979). Grapevine sprouts are capable of growing as much as 18-20 feet per year (Boring et al. 1981), and can then spread through the canopy from one tree to the next (Lennox 2001). To a wildlife manager, grapevines represent an excellent source of food for over 80 species of songbirds, and other animals including black bear, deer, raccoon, quail, grouse, and turkey. Birds and squirrels also depend on the vines for suitable nesting sites (Shutts 1968).

Wild grapevines are prolific seed producers. Once they are established in a position to absorb sufficient sunlight, they can reproduce within 3 years (Shutts 1968). Vitis has the capacity to produce perfect flowers, but generally male and female flowers are borne on separate vines. Seed usually ripens from September to October. Seed crops are variable, but Della Bianca (1978) observed in North Carolina an average of 96 grapevines yielding 1,012 grape clusters per acre. Each cluster in turn averaged 42 berries, so that in an average year, 42,500 berries would be produced per acre. Each grape contained an average of 3 seeds (with a range of 2 to 6 seeds/grape), resulting in an average total of 127,500 seeds per acre. After typical mortality resulting from agents such as Guignardia black rot disease (Bost 2001), and insects such as curculio beetles (Craponius inaequalis) (Brooks 1918), roughly 10\% of the seed crop, or 12,750 grape seeds, would remain per acre. Vitis seed can remain viable in the soil at least 15 years (Smith 1989).

The term used for an opening that is dominated by Vitis is "grapevine arbor". In these 
areas, vines dominate by forming thick entangled mats that overtop trees and other vegetation (Morrissey et al. 2009). There is no practical way of eliminating these arbors. Aerial or mist spray treatments of large areas cannot be performed without damage to non-target vegetation (Smith and Smithson 1975; Lennox 2001). The most sensible strategy is to contain the infestation by cutting or spraying the vines in the trees surrounding the opening. In small openings, eventual canopy closure may suppress a grape arbor. Where large openings exist, crown closure will not occur, and it will not be possible to grow quality timber for many years (Smith 1984).

Where timber management on high quality stands is a priority, grapevines pose a considerable challenge (Smith 1989). A few years after cutting, it is common to encounter large numbers of grapevines on good to excellent hardwood sites (Smith 1984). Once vines are established in the canopy, they form thick masses and can successfully compete with their host trees for sunlight, often leading to reductions in photosynthesis (Barrett 1995). Damage by vines does not end during the growing season. During winter, thick grapevine tangles will trap heavy snowfall, or become encrusted with ice. This adds considerable weight to small branches, and leads to crown deformation or breakage (Morrissey et al. 2009).

Because grapevines can sprout vigorously from stumps when cut and their seed is abundant in the soil, they can be abundant after a clearcut (Trimble and Tryon 1979). When the objective is to grow quality timber, control measures will be necessary both before and after the overstory harvest (Smith and McCay 1979). Pre-harvest treatments can be carried out using herbicides, or by cutting vines near their base. If combined with vine severing, herbicide treatments were found by Smith (1984) to be most effective when applied during early March and late September, when the vines' sap is not bleeding. When herbicides are applied 
exclusively, and mixed with fuel oil, treatments are effective throughout the growing season. Reliable vine control can be attained by basal cutting, but only if performed at least 5 years prior to the planned clearcut, and beneath a closed canopy. The existing shade for that remaining time period will effectively suppress resulting stump sprouts. Pre-harvest treatments will only manage spouts, and do not account for the existing seed bank (Smith 1984).

Following a clearcut, a second round of treatments will be necessary to control seedling vines. These treatments should not be performed until the new stand has a closed canopy, usually when minimum tree height averages 18 feet and the forest floor is shaded (Trimble and Tryon 1979). Control of Vitis is usually only an issue on oak site index 70 or higher (Trimble 1973). The most influential assets in vine control are overstory shade and herbicides. When the harvest is imminent (within 4 years) and grapevine control is desired, but the use of herbicides is forbidden, vines should not be cut before, during or immediately after harvest (Smith 1984). 


\section{METHODOLOGY}

\section{Study Areas}

Data were collected from 15 clearcut stands on the Cheat Ranger District of the Monongahela National Forest from September, 2009 to April, 2010 (Figure 1). The oldest stand was clearcut in 1970, and the youngest stand was cut in 1990. All stands are considered representative of successful regeneration for the Central Appalachians. All sites were distributed within a 9 mile radius of Parsons, West Virginia, with thirteen stands located in Tucker County, and two in Randolph County. Sizes ranged from 8-46 acres, with an average of 18 acres. Plot elevations range from 2110 - 2920 feet above sea level. Slope gradients range from 12 to 50 degrees, with an average of 28 degrees. Soils are generally from the Calvin and DeKalb series. These are medium textured and well drained, and derived from sandstone shale with occasional limestone influence (Miller et al. 2001). The average soil depth exceeds 3 feet. Annual precipitation averages 57 inches and is well distributed throughout the year. The growing season averages 145 frost free days (Miller et al. 2001). Previous measurement data from 1999 and 2004 inventories were furnished by personnel at the USDA Forest Service Northern Research Station, in Morgantown, West Virginia. A map of the study area was prepared using ArcGIS $9.3^{\circledR}$ software, and georeferencing a U.S. Forest Service topographical map with a USGS county NAD83 layer.

\section{Field Methods}

Two plot sizes were used in this study: $1 / 40^{\text {th }}$ acre plots (18.6 foot radii) for the stands that are now $\leq 25$ years old, and $1 / 20^{\text {th }}$ acre plots (26.3 foot radii) for the older stands $\geq 26$ years old. A total of 195 plots were installed in the 15 stands. The number of plots per stand varied 


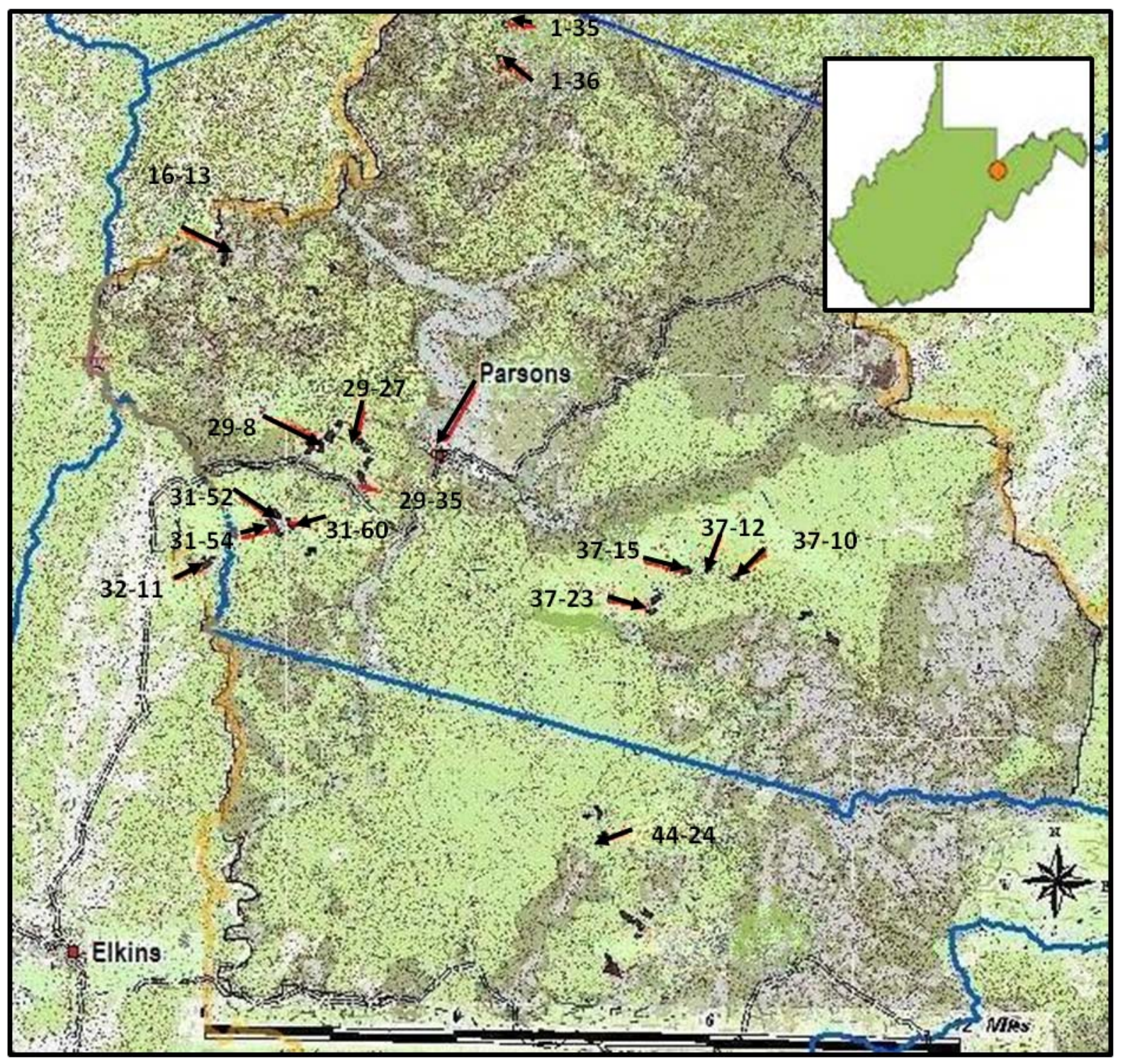

Figure 1. Locations of the 15 clearcut stands in the study area. 
with stand size, and ranged from 7 to 22. Plot centers were marked by an embedded fiberglass stake, with the plot number displayed on an attached brass tag. All live trees $\geq 1$ in dbh were recorded. Information for each tree included species, diameter at breast height (dbh), crown class, number of vines, and a rating for vine damage. Crown class ratings were (1) for dominant, (2) for codominant, (3) for intermediate, and (4) for overtopped/suppressed. The grapevine damage rating system included three degrees of severity: (1) when vines were present, but with low likelihood of causing serious damage for the next five years; (2) when reversible damage had occurred, and risk for serious damage was high for the next five years; and (3) when irreversible damage had occurred, and no potential products were obtainable from the host tree.

In addition, the measurement of total height was recorded for four codominant trees on each plot. This was usually possible, although on occasional plots there were not four suitable specimens. Tree heights and plot radii were determined with a LaserTech TruPulse $200^{\odot}$ rangefinder/hypsometer. Species were recorded using Forest Inventory Analysis codes. Slope percent and aspect were recorded upon arrival on each plot. Slope percent was determined using a Silva Ranger ${ }^{\odot}$ compass containing a clinometer in the base plate. Aspect was also recorded using a compass. Aspects were defined by the following azimuths: north $=316-45^{\circ}$, east $=46-135^{\circ}$, south $=136-225^{\circ}$ and west $=226-315^{\circ}$. Plot photographs were usually taken, and included 5 views: upslope, downslope, two opposing lateral views along the slope, and one picture directed upward at the canopy (Figure 2). The photos were often useful during the data evaluation process as references for stand structure and vegetative plot condition. An appendix at the end of this document includes five photo sets for each aspect.

Access to U. S.D.A. Forest Service roads was granted by the Forest Service and a set of keys was provided by the Cheat Ranger District Office in Parsons, West Virginia. Sample plot 

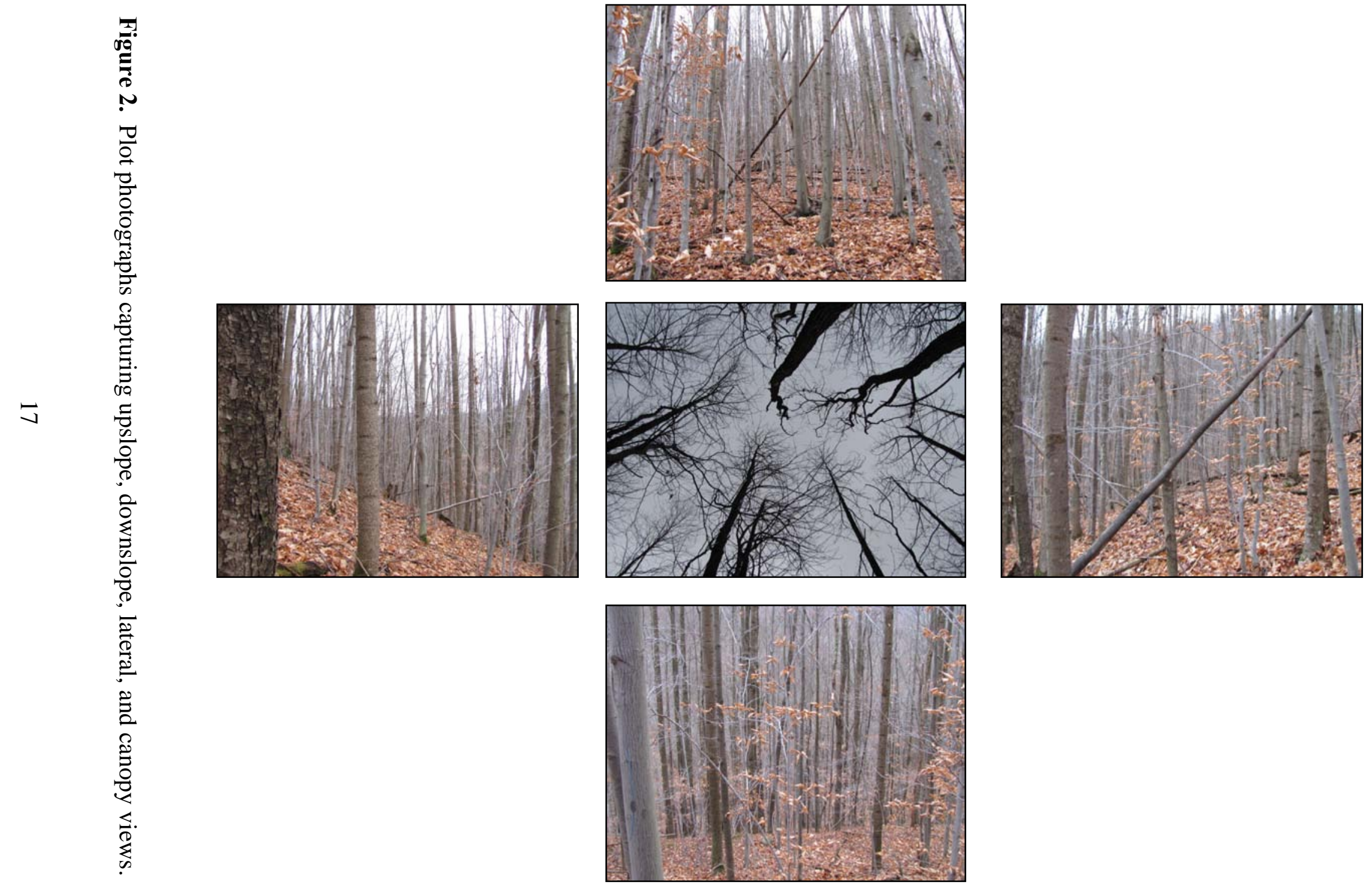
coordinates were also provided by the U.S.D.A. Forest Service. Plots were located in the field using a Silva Ranger ${ }^{\circledR}$ compass and a Garmin etrex ${ }^{\odot}$ GPS unit. Garmin Map Source ${ }^{\odot}$ software was downloaded to a laptop computer, permitting coordinates to be entered manually via the Map Source interface. The information was then transferred via USB cable to be stored in the Garmin etrex GPS unit. Topographical, stand, and plot level maps were furnished by personnel at the USDA Forest Service Northern Research Station in Morgantown, West Virginia.

\section{Data Analysis}

Of the 41 species recorded in 2009, 9 were prioritized for evaluation. These species include black birch, black cherry, black locust, oaks, “other”, red maple, sassafras, sugar maple, and yellow-poplar. The oak group was comprised mostly of northern red oak and chestnut oak, with fewer scarlet oak (Q. coccinea Muenchh.), white oak (Q. alba L.), and black oak (Quercus velutina Lam.). In the overstory, the group “others” consisted of American beech, American basswood (Tilia americana L.), bigtooth aspen (Populus grandidentata Michx.), blackgum (Nyssa sylvatica Marsh.), cucumbertree (Magnolia acuminata L.), Fraser magnolia (Magnolia fraseri Walt.), eastern hemlock (Tsuga canadensis (L.) Carr.), hickory (Carya spp), pin cherry, sourwood (Oxydendrum arboreum (L.) DC.), staghorn sumac, striped maple, white ash (Fraxinus americana L.), white pine (Pinus strobus L.), and yellow birch (Betula alleghaniensis Britton).

Stand structure and species composition in 1999, 2004, and 2009 were summarized from three perspectives: development of all stands combined, development by age-class, and development by aspect. In the analysis of all stands combined, all study stands were merged regardless of age or topographical differences. In the second analysis, stands were divided into 
three age classes to permit evaluation of stand development during different intervals. Age classes consisted of 55 plots aged $\leq 25$ years, 62 plots $26-35$ years old, and 78 plots $>35$ years old. Last, the influence of aspect on stand development was examined. Sites were distributed among five groups designated by the four primary compass points, and "summit" for sites occupying level areas. There were 99 southerly plots, 48 westerly, 25 easterly, 14 northerly, and 9 summits. Evaluations included basal area/acre $\left(\mathrm{ft}^{2}{ }^{2}\right)$ and density at the stand level for all trees $\geq 1$ inch dbh (trees/acre), as well as percent basal area and density at the species level for all dominants and codominants.

Because percentage data is often not normally distributed, it was necessary to evaluate the residuals of our data. The residual plots exhibited curvilinear, non-normal tendencies, and so a transformation was used. An ARCSIN transformation was performed using Excel 2007 ${ }^{\circledR}$, wherein each raw percentage figure was converted to a proportion, and then the arcsine of the square root of each proportion was calculated. The transformed ARCSIN values were subsequently tested for normality using the Shapiro-Wilk procedure in SAS 9.1.3. Output from the Shapiro-Wilk test included the W-statistic, normal quantile plots, and studentized residual histogram plots. Normality of the data is confirmed by a linear distribution of the data running in a southwest-to-northeast direction on the normal quantile plot, with no curvilinear tendencies. The data distribution presented as a studentized residual histogram was plotted beneath a bellshaped curve. A reasonable fit with no skewness was necessary as an indication of normality.

After reviewing the output and confirming that the data possessed a normal distribution, the transformed percentages were analyzed using repeated measures ANOVA, and the PROC MIXED procedure. The repeated measures procedure was used for most other analyses performed in the study. Analysis of vine infestation levels by aspect in 2009 was an exception, 
and was performed using one-way ANOVA. Data presented in the tables for percent basal area analyses are the original data. Transformed data were used solely for statistical analyses, but are not displayed. The Tukey-Kramer range test was used for multiple comparisons.

Graphs and tables presented in this paper were all created using Microsoft Office Excel $2007^{\odot}$. Statistical analyses were performed using SAS version $9.1 .3^{\odot}$ created for Windows $^{\circledR}$. Bar graphs were labeled with alphabetical notations. A change in alphabetical notations indicates a statistically significant difference between means over time $(\mathrm{P} \leq 0.05)$. Bar graphs for basal area/acre and density analysis included only trees $\geq 1$ inch dbh (except in the br oadscale analysis wherein the overstory trees were included). Species level data for percent basal area and density of overstory trees were displayed in separate data tables.

Changes in grapevine infestation levels over time and their distribution by aspects in 2009 were also evaluated. Calculations for determining the relative severities of infestations were performed by adding the numbers of infested trees tallied in each of the three damage classes (damage imminent, damage evident with a high risk for the next five years, and damage irreversible) and dividing by the total number of canopy trees recorded during the year, or on the aspect of interest. For evaluating the effect of slope aspect, all plots were included, infested or not. This was done because aspect dictates site moisture conditions, and the inclusion of all plots reveals both the best and least favorable host sites for vines in the study. A similar method was used for evaluating the changes in overstory infestation levels over time, except that only infested plots were included. Focusing on the infested stands permitted observation of whether vine infestations worsen, without diluting results by including unthreatened sites. 


\section{RESULTS}

\section{All Stands Combined}

From 1999-2009, mean basal area of the 15 study sites increased significantly $(\mathrm{P}=0.0001)$ for all trees 1 inch dbh and larger (Figure 3). From 1999-2004 basal area significantly increased 4ft ${ }^{2} / \mathrm{ac} / \mathrm{yr}$ from 82-103 $\mathrm{ft}^{2} / \mathrm{ac}(\mathrm{P}<0.0001)$, and from 2004-2009 it increased $3 \mathrm{ft}^{2} / \mathrm{ac} / \mathrm{yr}$ from 103$118 \mathrm{ft}^{2} /$ ac $(\mathrm{P}=0.0002)$. A 10 -year increase in mean basal area $(\mathrm{P}=0.0001)$ was also observed in overstory trees (dominants and codominants). From 1999-2004 basal area increased from 55-69 $\mathrm{ft}^{2} / \mathrm{ac}(\mathrm{P}<0.0001)$, and from 2004 to 2009 it increased from $69-85 \mathrm{ft}^{2} / \mathrm{ac}(\mathrm{P}<0.0001)$.

In contrast to basal area, mean stand density decreased significantly $(\mathrm{P}<0.0001)$ over the course of the study (Figure 4). From 1999-2009 trees 1-inch dbh and larger declined from 1,530 to 1,065 trees per acre. A significant five-year decrease occurred between 2004 and 2009 $(\mathrm{P}=0.0001)$. Among overstory trees, a significant reduction $(\mathrm{P}<0.0001)$ occurred over the study period as density diminished from 475-302 trees per acre. There was also a significant reduction from 1999-2004 $(\mathrm{P}=0.0346)$.

In 1999, the average height of codominant trees was 45.1 feet, and by 2004 it had increased ( $\mathrm{P}<0.0001)$ to 55.3 feet (Figure 5). After 2004, continued height gains were significant $(\mathrm{P}<0.0062)$ so that by 2009 the codominant trees averaged 60.3 feet. The 10 -year periodic annual increment was 1.5 feet.

During the study period, the percent basal area of the overstory trees was dominated by the same species: yellow-poplar, oaks (northern red oak, chestnut oak, scarlet oak, black oak, and white oak), others (a collection of 15 minor species), red maple, and black cherry (Table 1). These species combined for 78-82\% of overstory basal area during each sampling period. 


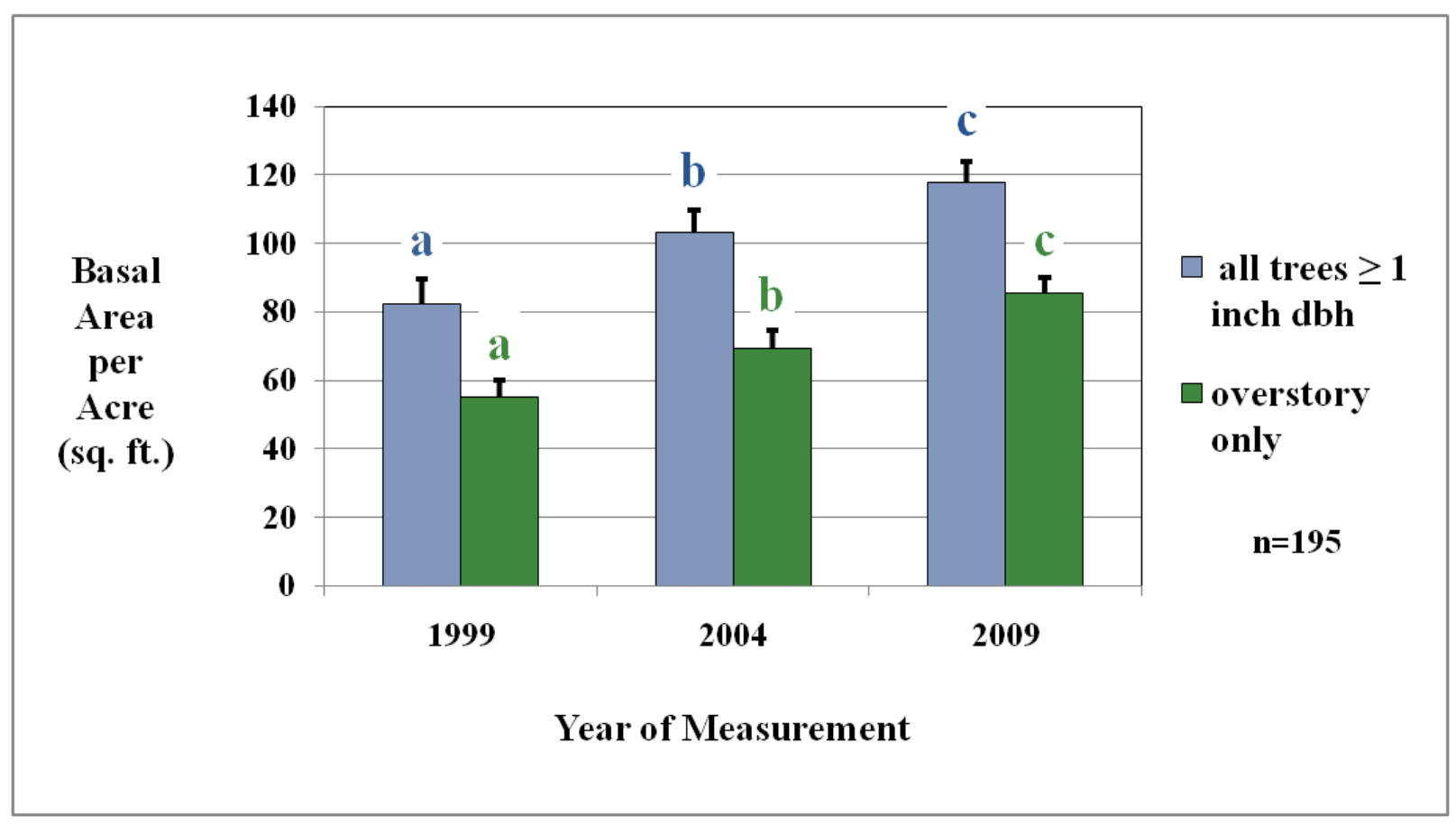

Figure 3. Changes in mean basal area per acre for 15 clearcut stands in West Virginia from 1999-2009. Includes all trees $\geq 1$ inch dbh and overstory trees (dominants and codominants). Vertical lines above the means represent standard errors. A change in alphabetical notations indicates a significant difference between means over time $(\mathrm{P} \leq 0.05)$. 


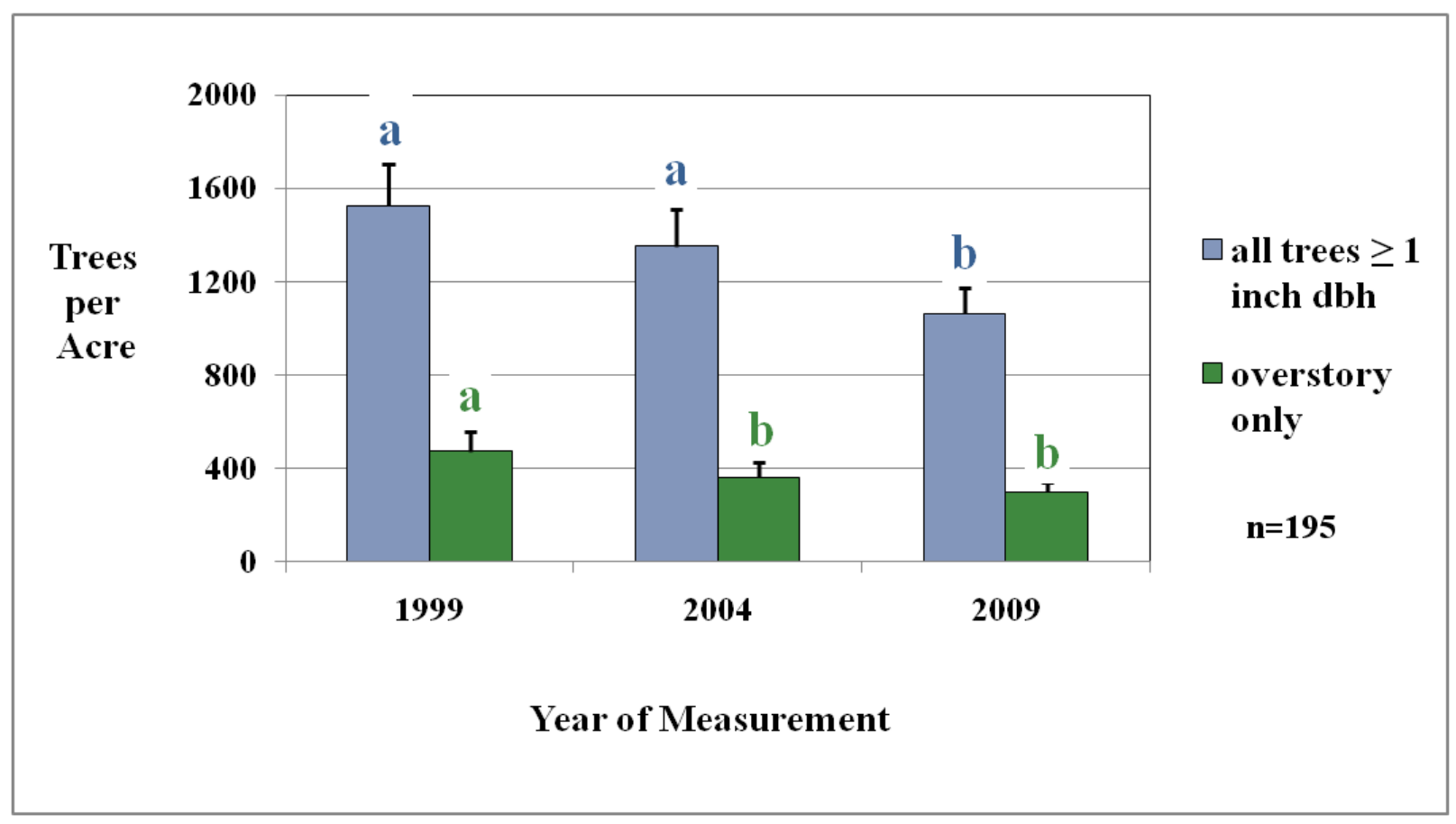

Figure 4. Changes in mean stand density for 15 clearcut stands in West Virginia from 19992009. Includes all trees $\geq 1$ inch dbh and overstory trees (dominants and codominants). Vertical lines above the means represent standard errors. A change in alphabetical notations indicates a significant difference between means over time $(\mathrm{P} \leq 0.05)$. 


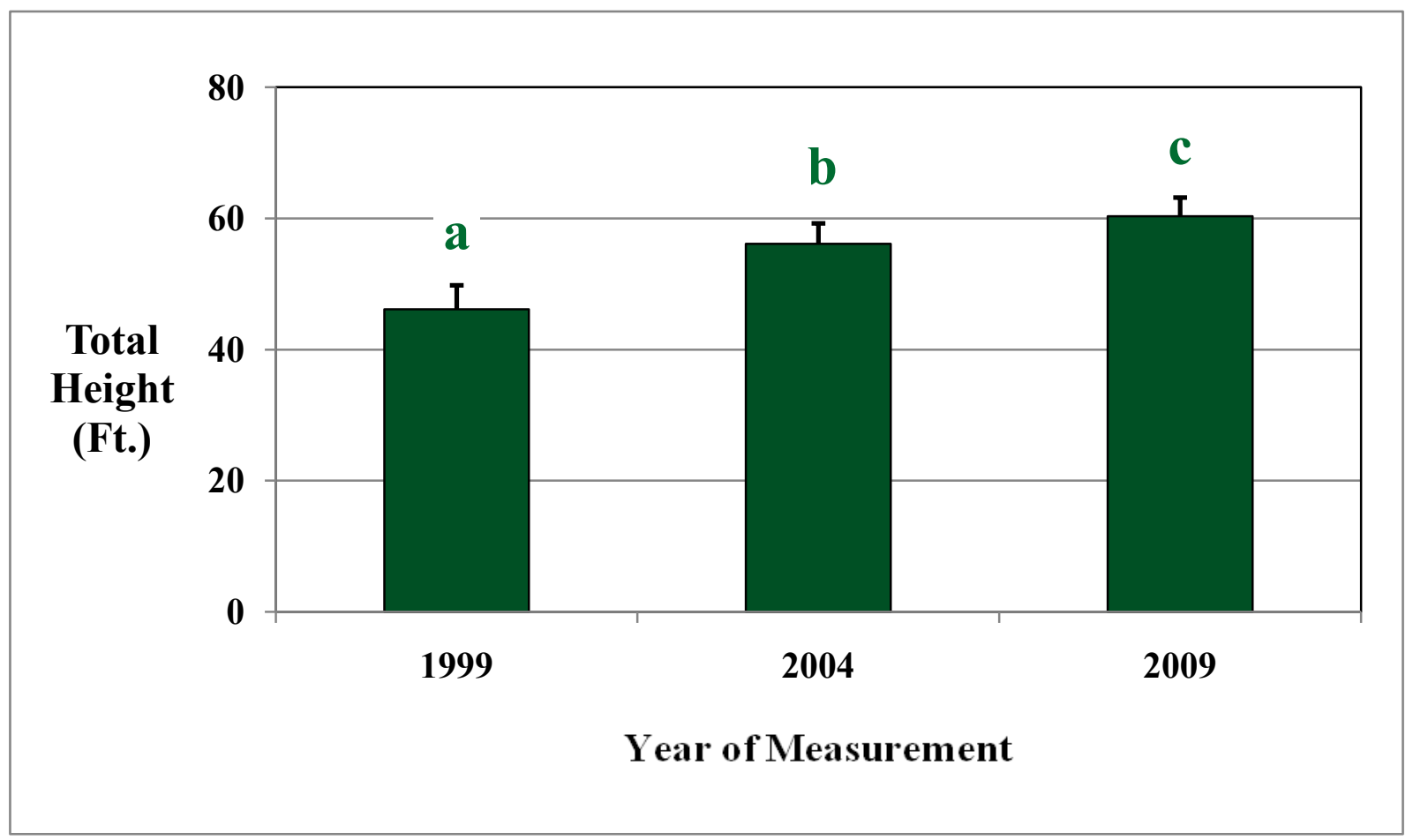

Figure 5. Changes in mean height of codominant trees on 15 clearcut stands in West Virginia from 1999-2009. Vertical lines above the means represent standard errors. A change in alphabetical notations indicates a significant difference between means $(P \leq 0.05) ; n=195$. 
Table 1. Changes in percent basal area of overstory trees (dominants and codominants) on 15 clearcut stands in West Virginia from 1999-2009. P-values are included where $\mathrm{P} \leq 0.05$; $\mathrm{n}=195$.

\begin{tabular}{|c|c|c|c|c|c|c|c|}
\hline Species & $1999 \%$ & StErr $_{1999}$ & $2004 \%$ & StErr $_{2004}$ & $2009 \%$ & StErr $_{2009}$ & P-value \\
\hline yellow-poplar & $20.4^{\mathrm{a}}$ & 1.9 & $23.9^{\mathrm{a}}$ & 2.1 & $26.6^{\mathrm{ab}}$ & 2.2 & $<0.0001$ \\
\hline oaks $^{1}$ & 22.1 & 1.9 & 22.8 & 2.0 & 23.6 & 2.0 & \\
\hline others $^{2}$ & 15.7 & 1.4 & 14.2 & 1.4 & 13.0 & 1.4 & \\
\hline red maple & $12.0^{\mathrm{a}}$ & 1.2 & $9.9^{\mathrm{a}}$ & 1.1 & $9.1^{\mathrm{ab}}$ & 1.1 & 0.0147 \\
\hline black cherry & 8.3 & 1.2 & 9.2 & 1.3 & 8.9 & 1.3 & \\
\hline black birch & 6.2 & 1.0 & 6.2 & 1.1 & 6.3 & 1.0 & \\
\hline sugar maple & 5.1 & 1.0 & 3.7 & 0.9 & 4.5 & 1.0 & \\
\hline black locust & 5.3 & 1.1 & 5.2 & 1.1 & 4.3 & 0.9 & \\
\hline sassafras & 4.9 & 0.8 & 4.9 & 0.8 & 3.7 & 0.7 & \\
\hline total & 100.0 & & 100.0 & & 100.0 & & \\
\hline
\end{tabular}

${ }^{1}$ includes northern red oak, chestnut oak, scarlet oak, white oak, and black oak.

2 includes American basswood, American beech, bigtooth aspen, blackgum, cucumbertree, Fraser magnolia, eastern hemlock, hickory, pin cherry, sourwood, staghorn sumac, striped maple, white ash, white pine, and yellow birch. 
Between 18-22\% of basal area was made up of black birch, sugar maple, black locust, and sassafras. From 1999-2009 yellow-poplar increased significantly ( $<$ < 0.0001) from 20.4- 26.6\% of the total stand basal area. Red maple diminished significantly between 1999 and 2009 by dropping from 12.0 to $9.1 \%$ of the total stand basal area $(\mathrm{P}=0.0147)$.

Examining the density of overstory trees for all stands combined (Table 2), the oaks accounted for more stems than any other single species, with an average of 88-67 per acre from 1999-2009. Yellow-poplar was well represented with 68-55 trees per acre. Black birch was the only species that underwent significant change, declining in presence from 71 stems in 1999 to 36 in 2009 ( $P=0.0022)$. Sugar maple sustained the only increase in numbers from 2004 to 2009, although the difference was non-significant.

\section{Stand Development by Age Class}

When all trees $\geq 1$ inch in diameter were partitioned into age groups, significant increases in mean basal area were observed over time (Figure 6). In stands aged $\leq 25$ years, average basal area increased from 56-81 ft²/acre during 1999-2004 (P < 0.0001), and 81-104 $\mathrm{ft}^{2}$ /acre from 2004-2009 ( $<$ 0.0001). In stands aged 26-35 years, significant growth occurred between all measurements. From 1999-2004, basal area increased from 92-114 $\mathrm{ft}^{2} /$ acre $(\mathrm{P}<0.0001)$, and reached $131 \mathrm{ft}^{2} /$ acre in $2009(\mathrm{P}<0.0001)$. In stands aged $>35$ years, basal area increased from 99 to $115 \mathrm{ft}^{2} /$ acre between 1999 and 2004 (P < 0.0001), but increased to only 119 square feet in $2009(\mathrm{P}=0.2219)$.

Significant reductions in stand density occurred over time for all age groups (Figure 7).

From 1999-2004, stands aged $\leq 25$ years diminished significantly $(\mathrm{P}<0.0001)$ from 2,185-2,030 trees/acre. From 2004-2009, their numbers declined to 1,420 stems $(\mathrm{P}<0.0001)$. Stands aged 26- 
Table 2. Changes in stand density of overstory trees (dominants and codominants) on 15 clearcut stands in West Virginia from 1999-2009. $\mathrm{P}$-values are included where $\mathrm{P} \leq 0.05 ; \mathrm{n}=195$.

\begin{tabular}{|c|c|c|c|c|c|c|c|}
\hline Species & 1999 TPA & StErr $_{1999}$ & 2004 TPA & StErr $_{2004}$ & 2009 TPA & StErr $_{2009}$ & P-value \\
\hline yellow-poplar & 68 & 8 & 55 & 6 & 55 & 6 & \\
\hline oaks & 88 & 5 & 73 & 4 & 67 & 5 & \\
\hline others & 81 & 3 & 51 & 2 & 42 & 3 & \\
\hline red maple & 64 & 8 & 45 & 6 & 36 & 5 & \\
\hline black cherry & 24 & 3 & 25 & 4 & 20 & 3 & \\
\hline black birch & $71^{\mathrm{a}}$ & 16 & $57^{\mathrm{a}}$ & 12 & $36^{\mathrm{ab}}$ & 7 & 0.0022 \\
\hline sugar maple & 15 & 3 & 7 & 1 & 13 & 4 & \\
\hline black locust & 22 & 5 & 17 & 4 & 12 & 2 & \\
\hline sassafras & 42 & 6 & 34 & 5 & 21 & 3 & \\
\hline total & $475^{\mathrm{a}}$ & 25 & $364^{b}$ & 18 & $302^{C}$ & 12 & $<0.0001$ \\
\hline
\end{tabular}




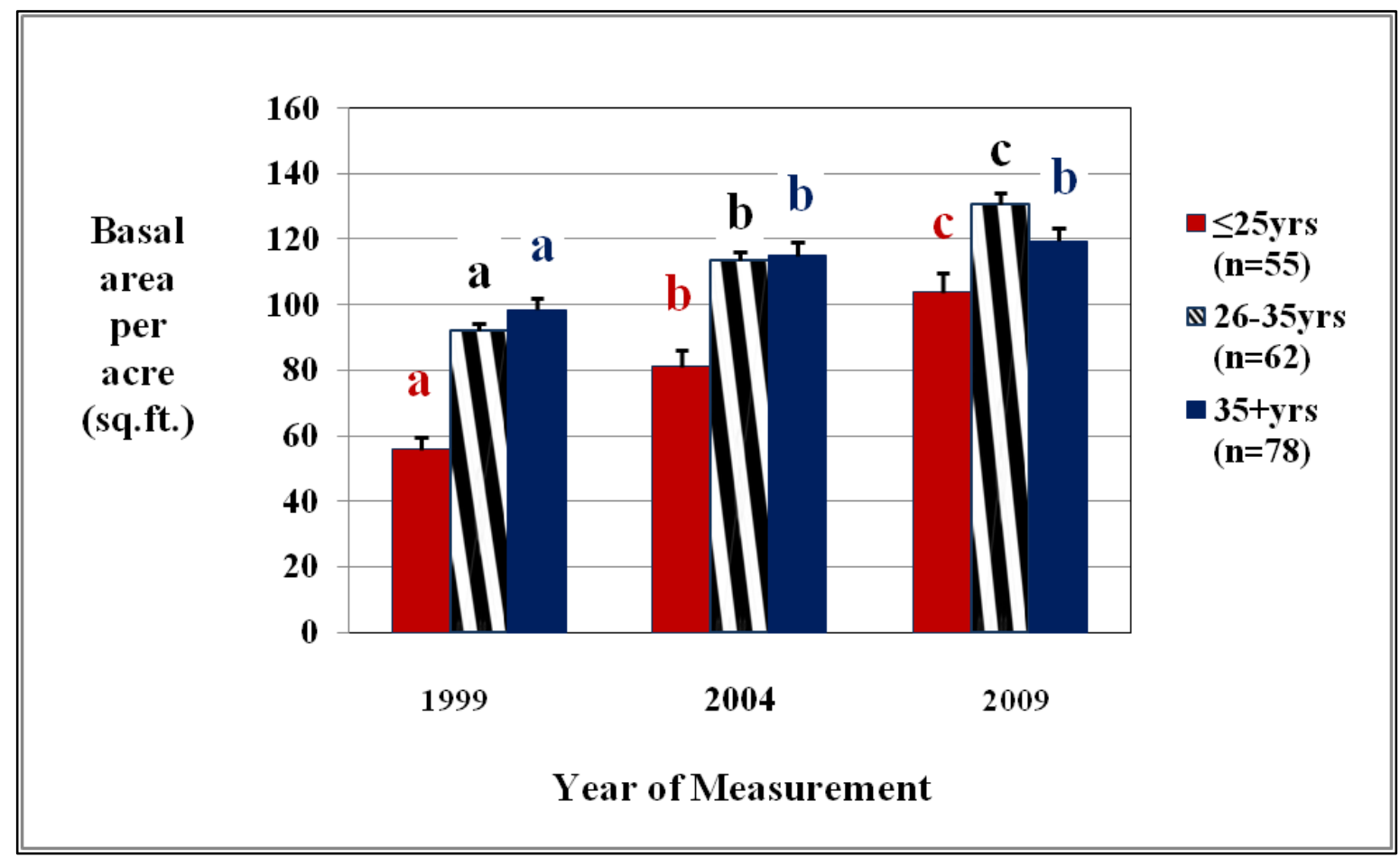

Figure 6. Changes in mean basal area per acre by age class for trees $\geq 1$ inch $\mathrm{dbh}$ on 15 clearcut stands in West Virginia from 1999-2009. Vertical lines above the means represent standard errors. A change in the alphabetical notations indicates a significant difference between means over time $(\mathrm{P} \leq 0.05)$. 


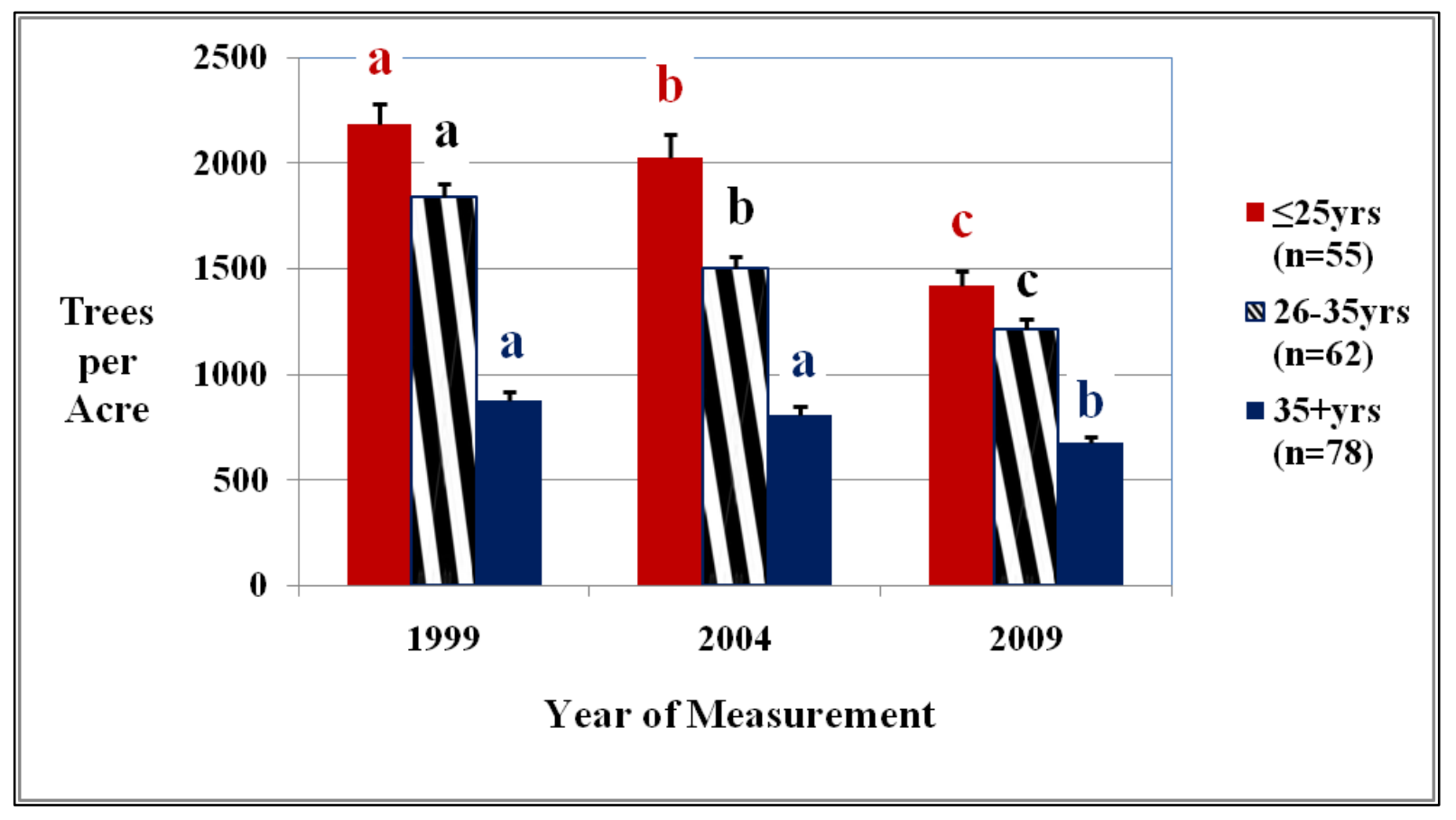

Figure 7. Changes in mean stand density by age class for trees $\geq 1$ inch dbh on 15 clearcut stands in West Virginia from 1999-2009. Vertical lines above the means represent standard errors. A change in the alphabetical notations indicates a significant difference between means over time $(\mathrm{P} \leq 0.05)$. 
35 years sustained significant decreases $(\mathrm{P}=0.0001)$ between all measurements, diminishing from 1,840-1,500 trees/acre between 1999-2004 and declining to 1,215 trees/acre by 2009. In stands aged $>35$ years, density was 875 in 1999, 810 in 2004, and 675 in 2009. Only the last 5-year reduction was statistically significant $(\mathrm{P}=0.0161)$.

The distribution of percent basal area of the overstory trees exhibited non-significant changes from 1999-2009 for all species in all age classes (Table 3). Yellow-poplar and oaks were dominant in all age classes, generally increased in percentage with each measurement, and collectively occupied $39-55 \%$ of total stand basal area in all sampling periods. Of the remaining species, “others”, red maple, and black cherry showed a combined presence ranging from $40.9 \%$ of basal area in stands aged $>35$ years in 1999, to $25.6 \%$ of basal area in stands $\leq 25$ years old in 2009. From 1999-2009, black birch, black locust, sassafras, and sugar maple accounted for 27 $31 \%$ of stand basal area in stands $\leq 25$ years old, but occupied less than $20 \%$ in the median and oldest age classes over the study period.

In the density distribution of overstory trees in stands aged $\leq 25$ years (Table 4 ), oaks were most the abundant species in 2009, followed by black birch and "others". Black birch declined from 191 to 83 trees/acre from 1999-2009 ( $\mathrm{P}<0.0001$ ). All other species decreased in density over time, with the exception of sugar maple, which increased from 31-35 trees/acre from 1999-2009 $(\mathrm{P}=0.1104)$. The overstories of stands $26-35$ years old, and stands $>35$ years old were dominated by yellow-poplar and oaks. In general, all species decreased in density over time. In the two youngest age groups, total overstory density decreased significantly over the study period $(\mathrm{P}<0.0001)$. In the oldest stands, total stand density remained constant at $186-187$ trees/acre from 2004-2009. 
Table 3. Changes in percent basal area of overstory trees (dominants and codominants) by age class on 15 clearcut stands in West Virginia from 1999-2009. P-values are included where $\mathrm{P} \leq$ 0.05 .

\begin{tabular}{|c|c|c|c|c|c|c|c|c|}
\hline Age Group & Species & $1999 \%$ & StErr $_{1999}$ & $2004 \%$ & StErr $_{2004}$ & $2009 \%$ & StErr $_{2009}$ & P-value \\
\hline$\leq 25 \mathrm{yrs}$ & yellow-poplar & 17.8 & 3.5 & 22.8 & 4.3 & 24.2 & 4.4 & \\
\hline \multirow[t]{8}{*}{$(n=55)$} & oaks & 21.3 & 3.5 & 20.5 & 3.6 & 23.1 & 3.9 & \\
\hline & others & 16.3 & 3.5 & 15.0 & 3.6 & 14.8 & 3.9 & \\
\hline & black birch & 13.2 & 3.1 & 12.0 & 3 & 12.0 & 2.9 & \\
\hline & sugar maple & 9.1 & 2.4 & 7.0 & 2.6 & 8.9 & 2.7 & \\
\hline & red maple & 10.8 & 2.3 & 7.8 & 2 & 6.4 & 1.9 & \\
\hline & black cherry & 3.1 & 1 & 5.5 & 1.9 & 4.4 & 1.6 & \\
\hline & black locust & 4.7 & 2.1 & 4.3 & 1.8 & 3.7 & 1.7 & \\
\hline & sassafras & 3.7 & 1.2 & 5.1 & 1.5 & 2.5 & 1.0 & \\
\hline total & & 100.0 & & 100.0 & & 100.0 & & \\
\hline
\end{tabular}

\begin{tabular}{|c|c|c|c|c|c|c|c|c|}
\hline Age Group & Species & $1999 \%$ & StErr $_{1999}$ & $2004 \%$ & StErr $_{2004}$ & $2009 \%$ & StErr $_{2009}$ & P-value \\
\hline $26-35 y r s$ & oaks & 26.8 & 3.8 & 28.8 & 4.1 & 29.0 & 4.1 & \\
\hline \multirow[t]{8}{*}{$(n=62)$} & yellow-poplar & 21.0 & 3.3 & 24.8 & 3.5 & 25.6 & 3.6 & \\
\hline & red maple & 16.8 & 2.5 & 14.6 & 2.3 & 14.9 & 2.4 & \\
\hline & black cherry & 9.3 & 2.0 & 9.2 & 2.0 & 9.6 & 2.0 & \\
\hline & others & 8.6 & 1.2 & 7.1 & 1.3 & 6.5 & 1.1 & \\
\hline & black locust & 6.5 & 2.2 & 6.5 & 2.2 & 5.2 & 1.8 & \\
\hline & black birch & 3.3 & 0.7 & 3.3 & 0.7 & 3.7 & 0.9 & \\
\hline & sassafras & 3.2 & 1.0 & 2.6 & 0.8 & 2.9 & 0.9 & \\
\hline & sugar maple & 4.5 & 1.8 & 3.1 & 1.5 & 2.6 & 1.2 & \\
\hline total & & 100.0 & & 100.0 & & 100.0 & & \\
\hline
\end{tabular}

\begin{tabular}{|c|c|c|c|c|c|c|c|c|}
\hline Age Group & Species & $1999 \%$ & StErr $_{1999}$ & $2004 \%$ & StErr $_{2004}$ & $2009 \%$ & StErr $_{2009}$ & P-value \\
\hline $35+y r s$ & yellow-poplar & 21.7 & 3.0 & 24.0 & 3.2 & 29.0 & 3.6 & \\
\hline \multirow{8}{*}{$(n=78)$} & oaks & 18.8 & 2.6 & 19.7 & 2.8 & 19.6 & 2.8 & \\
\hline & others & 21.0 & 2.7 & 19.2 & 2.6 & 16.9 & 2.5 & \\
\hline & black cherry & 11.0 & 2.3 & 11.8 & 2.3 & 11.5 & 2.5 & \\
\hline & red maple & 8.9 & 1.5 & 7.7 & 1.4 & 6.5 & 1.3 & \\
\hline & sassafras & 7.4 & 1.5 & 6.7 & 1.5 & 5.2 & 1.3 & \\
\hline & black birch & 3.6 & 0.9 & 4.3 & 1.3 & 4.4 & 1.3 & \\
\hline & black locust & 4.9 & 1.5 & 4.9 & 1.6 & 4.1 & 1.4 & \\
\hline & sugar maple & 2.7 & 0.9 & 1.7 & 0.9 & 2.8 & 1.0 & \\
\hline total & & 100.0 & & 100.0 & & 100.0 & & \\
\hline
\end{tabular}


Table 4. Changes in stand density of overstory trees (dominants and codominants) by age class on 15 clearcut stands in West Virginia from 1999-2009. P-values are included where $\mathrm{P} \leq 0.05$.

\begin{tabular}{|c|c|c|c|c|c|c|c|c|}
\hline Age Group & Species & 1999 TPA & StErr $_{1999}$ & 2004 TPA & StErr $_{2004}$ & 2009 TPA & StErr $_{2009}$ & P-value \\
\hline$\leq 25 \mathrm{yrs}$ & yellow-poplar & 53 & 12 & 48 & 10 & 44 & 10 & \\
\hline \multirow[t]{8}{*}{$(n=55)$} & oaks & 121 & 21 & 96 & 16 & 90 & 16 & \\
\hline & others & 137 & 21 & 81 & 14 & 71 & 13 & \\
\hline & black birch & $191^{\mathrm{a}}$ & 52 & $152^{\mathrm{a}}$ & 39 & $83^{\mathrm{ab}}$ & 22 & $<0.0001$ \\
\hline & sugar maple & 31 & 8 & 11 & 4 & 35 & 11 & \\
\hline & red maple & 103 & 23 & 65 & 16 & 49 & 13 & \\
\hline & black cherry & 39 & 10 & 42 & 11 & 31 & 9 & \\
\hline & black locust & 25 & 15 & 20 & 9 & 10 & 5 & \\
\hline & sassafras & 53 & 12 & 46 & 12 & 30 & 9 & \\
\hline total & & $753^{\mathrm{a}}$ & 63 & $561^{b}$ & 43 & $443^{\mathrm{C}}$ & 27 & $<0.0001$ \\
\hline
\end{tabular}

\begin{tabular}{|c|c|c|c|c|c|c|c|c|}
\hline Age Group & Species & 1999 TPA & StErr $_{1999}$ & 2004 TPA & StErr $_{2004}$ & 2009 TPA & $\mathrm{StErr}_{2009}$ & P-value \\
\hline $26-35 y r s$ & oaks & 109 & 14 & 92 & 12 & 79 & 10 & \\
\hline \multirow[t]{8}{*}{$(n=62)$} & yellow-poplar & 97 & 18 & 76 & 13 & 76 & 12 & \\
\hline & red maple & 58 & 9 & 46 & 8 & 32 & 6 & \\
\hline & black cherry & 12 & 3 & 10 & 3 & 9 & 3 & \\
\hline & others & 96 & 12 & 70 & 10 & 44 & 7 & \\
\hline & black locust & 33 & 9 & 24 & 6 & 20 & 5 & \\
\hline & black birch & 44 & 10 & 35 & 9 & 33 & 8 & \\
\hline & sassafras & 75 & 15 & 56 & 12 & 30 & 6 & \\
\hline & sugar maple & 10 & 5 & 4 & 2 & 4 & 2 & \\
\hline total & & $534^{\mathrm{a}}$ & 21 & $413^{\mathrm{b}}$ & 18 & $327^{\mathrm{b}}$ & 14 & $<0.0001$ \\
\hline
\end{tabular}

\begin{tabular}{|c|c|c|c|c|c|c|c|c|}
\hline Age Group & Species & 1999 TPA & StErr $_{1999}$ & 2004 TPA & StErr $_{2004}$ & 2009 TPA & StErr $_{2009}$ & P-value \\
\hline $35+y r s$ & yellow-poplar & 54 & 10 & 42 & 7 & 45 & 7 & \\
\hline \multirow{8}{*}{$(n=78)$} & oaks & 47 & 8 & 42 & 7 & 42 & 7 & \\
\hline & others & 30 & 5 & 16 & 3 & 20 & 4 & \\
\hline & black cherry & 24 & 4 & 24 & 4 & 21 & 4 & \\
\hline & red maple & 41 & 7 & 30 & 5 & 31 & 5 & \\
\hline & sassafras & 8 & 3 & 8 & 3 & 9 & 3 & \\
\hline & black birch & 9 & 2 & 8 & 2 & 6 & 2 & \\
\hline & black locust & 12 & 4 & 11 & 4 & 7 & 3 & \\
\hline & sugar maple & 8 & 2 & 6 & 2 & 5 & 2 & \\
\hline total & & 233 & 13 & 187 & 12 & 186 & 10 & \\
\hline
\end{tabular}




\section{Stand Development by Aspect}

From 1999-2009, basal area significantly increased on all aspects (Table 5). Basal area accrual was greatest in all measurements on southerly slopes, where it increased from 93.6 $\mathrm{ft}^{2} /$ acre in 1999 to $132.2 \mathrm{ft}^{2} /$ acre in $2009(\mathrm{P}<0.0001)$. By the most recent basal area sampling period, summits ranked behind southerly slopes, which were followed by the west, north, and east facing aspects. In 2009, east slopes averaged $93.7 \mathrm{ft}^{2} /$ acre.

Stand density significantly decreased from 1999-2009 on all aspects but north (Table 6). Stand density was greatest on summit sites, declining from 2,331 trees/acre in 1999 to 1545 in 2009. Lowest densities were encountered on the mesic easterly and northerly slopes. Easterly sites diminished from 1,098-853 trees/acre during the study $(\mathrm{P}=0.0391)$, while from 1999-2009, northerly sites exhibited a non-significant decrease from 637-491 trees/acre.

Changes in percent basal area in the overstory from 1999-2009 were non-significant for all species on all aspects (Table 7). Composition was such that yellow-poplar dominated the mesic east and north facing sites in all measurement periods, ranging from $24.5 \%$ of stand basal area on north aspects in 1999 to $38.2 \%$ on easterly aspects in 2009. Yellow-poplar also dominated southerly sites, increasing from 22.8-30.5\% from 1999-2009. Oaks were dominant on summit and westerly aspects, and occupied from 33.5 - 34.7 \% of stand basal area in 1999 and from $35.8-41.1 \%$ in 2009.

Changes in overstory density on north, east and southern aspects were non-significant throughout the study, and yellow-poplar was the most abundant species on these aspects in 2009 (Table 8). Sugar maple was second in abundance on east and north aspects, while oak was ranked second on southerly sites. Total overstory density decreased significantly on southerly 
Table 5. Changes in mean basal area per acre by aspect for all trees $\geq 1$ inch dbh on 15 clearcut stands in West Virginia from 1999-2009. $\mathrm{P}$-values are included where $\mathrm{P} \leq 0.05$.

\begin{tabular}{|llllllll|}
\hline As pect & $\left.\mathbf{1 9 9 9} \mathbf{( f t}^{\mathbf{2}} / \mathbf{a c r e}\right)$ & $\mathbf{S t E r r}_{\mathbf{1 9 9}}$ & $\left.\mathbf{2 0 0 4} \mathbf{( f t}^{\mathbf{2}} / \mathbf{a c r e}\right)$ & $\mathbf{S t E r r}_{\mathbf{2 0 0 4}}$ & $\mathbf{2 0 0 9}\left(\mathbf{f t}^{\mathbf{2}} / \mathbf{a c r e}\right)$ & $\mathbf{S t E r r}_{\mathbf{2 0 0 9}}$ & $\mathbf{P}_{\text {-value }}$ \\
\hline Southerly (n=99) & $93.6^{\mathrm{a}}$ & 2.4 & $117.1^{\mathrm{b}}$ & 3.0 & $132.2^{\mathrm{c}}$ & 3.5 & $<0.0001$ \\
Summit (n=9) & $72.4^{\mathrm{a}}$ & 11.5 & $96.7^{\mathrm{b}}$ & 9.0 & $118.9^{\mathrm{b}}$ & 5.6 & $<0.0001$ \\
Westerly (n=48) & $78.8^{\mathrm{a}}$ & 5.5 & $98.8^{\mathrm{b}}$ & 5.0 & $112.6^{\mathrm{c}}$ & 4.4 & $<0.0001$ \\
Northerly (n=14) & $76.8^{\mathrm{a}}$ & 7.4 & $86.6^{\mathrm{a}}$ & 8.2 & $97.1^{\mathrm{ab}}$ & 10.1 & 0.0244 \\
Easterly (n=25) & $72.4^{\mathrm{a}}$ & 6.6 & $83.8^{\mathrm{a}}$ & 8.3 & $93.7^{\mathrm{ab}}$ & 7.7 & $<0.0001$ \\
\hline
\end{tabular}


Table 6. Changes in stand density by aspect for trees $\geq 1$ inch dbh on 15 stands in West Virginia from 1999-2009. P-values are included where $\mathrm{P} \leq 0.05$.

\begin{tabular}{|c|c|c|c|c|c|c|c|}
\hline Aspect & 1999 TPA & StErr $_{1999}$ & 2004 TPA & StErr $_{2004}$ & 2009 TPA & StErr $_{2009}$ & P-value \\
\hline Southerly (n=99) & $1487^{\mathrm{a}}$ & 60 & $1229^{\mathrm{b}}$ & 45 & $968^{\mathrm{C}}$ & 35 & $<0.0001$ \\
\hline Summit (n=9) & $2331^{\mathrm{a}}$ & 302 & $2089^{a}$ & 276 & $1545^{\mathrm{b}}$ & 169 & $<0.0001$ \\
\hline Westerly (n=48) & $1947^{\mathrm{a}}$ & 107 & $1870^{\mathrm{a}}$ & 114 & $1376^{b}$ & 81 & $<0.0001$ \\
\hline Northerly (n=14) & 637 & 103 & 600 & 91 & 491 & 76 & \\
\hline Easterly (n=25) & $1098^{\mathrm{a}}$ & 145 & $934^{\mathrm{a}}$ & 121 & $853^{a b}$ & 95 & 0.0391 \\
\hline
\end{tabular}


Table 7. Changes in percent basal area of overstory trees (dominants and codominants) by aspect on 15 clearcut stands in West Virginia from 1999-2009. Pvalues are included where $\mathrm{P} \leq 0.05$.

\begin{tabular}{|c|c|c|c|c|c|c|c|c|}
\hline Easterly & Species & $1999 \%$ & StErr & $2004 \%$ & StErr & $2009 \%$ & StErr & P-value \\
\hline \multirow[t]{9}{*}{$\mathrm{n}=25$} & yellow-poplar & 28.7 & 6.2 & 37.0 & 7.4 & 38.2 & 7.0 & \\
\hline & others & 19.2 & 4.1 & 16.2 & 3.7 & 15.7 & 4.1 & \\
\hline & sugar maple & 13.4 & 4.1 & 10.1 & 4.1 & 11.8 & 4.3 & \\
\hline & oaks & 6.4 & 2.7 & 10.3 & 5.0 & 10.2 & 4.9 & \\
\hline & black locust & 10.4 & 4.8 & 10.5 & 4.7 & 8.3 & 3.7 & \\
\hline & black cherry & 9.7 & 3.7 & 7.5 & 3.2 & 5.7 & 2.5 & \\
\hline & red maple & 5.6 & 2.0 & 2.4 & 1.0 & 5.1 & 2.7 & \\
\hline & sassafras & 5.3 & 2.4 & 5.3 & 2.8 & 4.3 & 2.3 & \\
\hline & black birch & 1.3 & 0.6 & 0.7 & 0.5 & 0.7 & 0.4 & \\
\hline total & & 100.0 & & 100.0 & & 100.0 & & \\
\hline
\end{tabular}

\begin{tabular}{|c|c|c|c|c|c|c|c|c|}
\hline Northerly & Species & $1999 \%$ & StErr & $2004 \%$ & StErr & $2009 \%$ & StErr & P-value \\
\hline \multirow[t]{9}{*}{$\mathrm{n}=14$} & yellow-poplar & 24.5 & 5.8 & 31.0 & 7.5 & 30.6 & 7.7 & \\
\hline & oaks & 13.4 & 6.2 & 12.9 & 6.0 & 17.9 & 8.4 & \\
\hline & sugar maple & 26.0 & 7.6 & 22.5 & 9.0 & 16.9 & 7.4 & \\
\hline & others & 11.0 & 4.7 & 5.2 & 3.5 & 10.7 & 4.9 & \\
\hline & red maple & 9.7 & 5.8 & 11.4 & 6.4 & 9.5 & 6.4 & \\
\hline & black cherry & 5.6 & 3.5 & 5.7 & 4.0 & 6.7 & 4.7 & \\
\hline & black locust & 7.0 & 3.9 & 5.8 & 4.2 & 5.9 & 4.0 & \\
\hline & black birch & 1.7 & 0.7 & 1.5 & 0.8 & 1.5 & 0.8 & \\
\hline & sassafras & 1.1 & 1.1 & 4.0 & 2.5 & 0.3 & 0.3 & \\
\hline
\end{tabular}

\begin{tabular}{|c|c|c|c|c|c|c|c|c|}
\hline Southerly & Species & $1999 \%$ & StErr & $2004 \%$ & StErr & $2009 \%$ & StErr & P-value \\
\hline \multirow[t]{9}{*}{$\mathrm{n}=99$} & yellow-poplar & 22.8 & 2.8 & 26.4 & 2.9 & 30.5 & 3.3 & \\
\hline & oaks & 20.5 & 2.5 & 19.8 & 2.5 & 20.2 & 2.5 & \\
\hline & others & 17.2 & 2.2 & 15.8 & 2.3 & 13.0 & 2.1 & \\
\hline & black cherry & 10.2 & 1.8 & 11.2 & 2.0 & 10.7 & 2.0 & \\
\hline & red maple & 10.5 & 1.5 & 9.0 & 1.4 & 8.5 & 1.4 & \\
\hline & black birch & 4.5 & 0.7 & 4.8 & 0.7 & 5.1 & 1.0 & \\
\hline & sassafras & 6.7 & 1.3 & 6.2 & 1.2 & 4.9 & 1.2 & \\
\hline & black locust & 5.6 & 1.5 & 5.5 & 1.5 & 4.7 & 1.3 & \\
\hline & sugar maple & 2.0 & 0.6 & 1.3 & 0.4 & 2.4 & 0.8 & \\
\hline total & & 100.0 & & 100.0 & & 100.0 & & \\
\hline
\end{tabular}

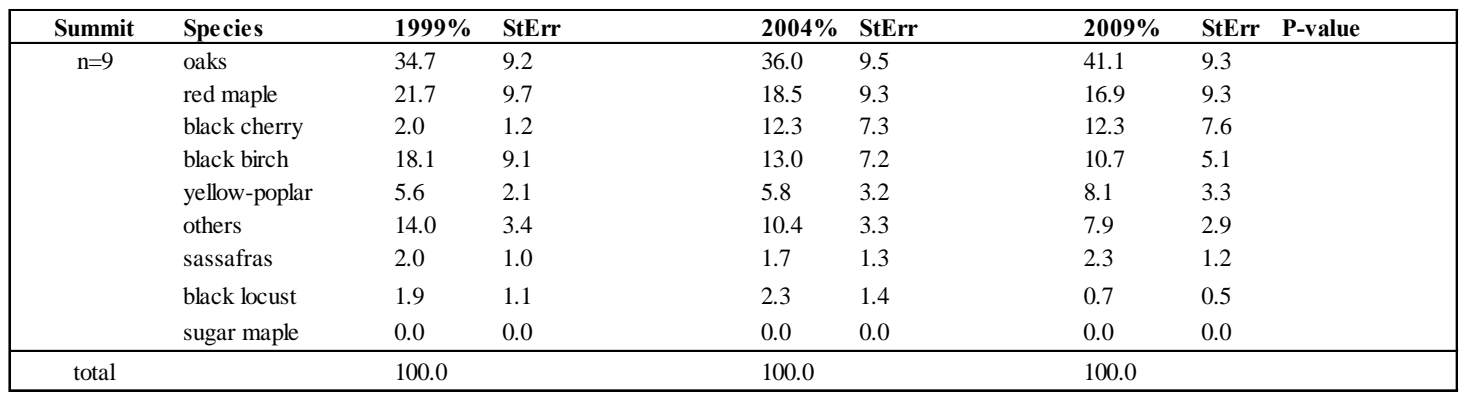

\begin{tabular}{|c|c|c|c|c|c|c|c|c|}
\hline Westerly & Species & $1999 \%$ & StErr & $2004 \%$ & StErr & $2009 \%$ & StErr & P-value \\
\hline \multirow[t]{9}{*}{$\mathrm{n}=48$} & oaks & 33.5 & 4.3 & 36.1 & 4.5 & 35.8 & 4.6 & \\
\hline & yellow-poplar & 12.5 & 3.1 & 13.2 & 3.1 & 14.7 & 3.4 & \\
\hline & others & 12.5 & 2.2 & 13.0 & 2.3 & 13.8 & 2.5 & \\
\hline & black birch & 11.6 & 3.1 & 11.9 & 3.2 & 11.8 & 3.1 & \\
\hline & red maple & 17.1 & 2.5 & 13.7 & 2.2 & 11.0 & 2.0 & \\
\hline & black cherry & 5.5 & 1.9 & 6.3 & 1.8 & 6.8 & 2.1 & \\
\hline & sugar maple & 1.9 & 1.1 & 0.6 & 0.4 & 2.2 & 1.2 & \\
\hline & sassafras & 3.2 & 0.9 & 2.8 & 1.1 & 2.1 & 0.7 & \\
\hline & black locust & 2.2 & 1.6 & 2.4 & 1.4 & 1.8 & 1.3 & \\
\hline total & & 100.0 & & 100.0 & & 100.0 & & \\
\hline
\end{tabular}


Table 8. Changes in stand density of overstory trees (dominants and codominants) by aspect on 15 clearcut stands in West Virginia from 1999-2009. P-values are included where $\mathrm{P} \leq 0.05$.

\begin{tabular}{|c|c|c|c|c|c|c|c|c|}
\hline Slope Aspect & Species & 1999 TPA & StErr & 2004 TPA & StErr & 2009 TPA & StErr & P-value \\
\hline Easterly & yellow-poplar & 63 & 18 & 48 & 12 & 51 & 11 & \\
\hline \multirow[t]{8}{*}{$n=25$} & others & 74 & 6 & 33 & 4 & 41 & 3 & \\
\hline & sugar maple & 41 & 15 & 13 & 5 & 43 & 23 & \\
\hline & oaks & 15 & 2 & 16 & 3 & 14 & 2 & \\
\hline & black locust & 20 & 10 & 18 & 8 & 12 & 7 & \\
\hline & black cherry & 15 & 5 & 12 & 5 & 10 & 4 & \\
\hline & red maple & 22 & 10 & 11 & 6 & 10 & 4 & \\
\hline & sassafras & 29 & 14 & 26 & 16 & 18 & 11 & \\
\hline & black birch & 6 & 4 & 2 & 1 & 2 & 1 & \\
\hline total & & 285 & 39 & 179 & 29 & 201 & 28 & \\
\hline Slope Aspect & Species & 1999 TPA & StErr & 2004 TPA & StErr & 2009 TPA & StErr & P-value \\
\hline Northerly & yellow-poplar & 34 & 12 & 23 & 6 & 30 & 9 & \\
\hline \multirow[t]{8}{*}{$n=14$} & oaks & 24 & 5 & 20 & 7 & 21 & 7 & \\
\hline & sugar maple & 47 & 17 & 27 & 11 & 27 & 11 & \\
\hline & others & 39 & 6 & 9 & 3 & 20 & 5 & \\
\hline & red maple & 21 & 14 & 17 & 11 & 14 & 11 & \\
\hline & black cherry & 11 & 9 & 4 & 2 & 4 & 2 & \\
\hline & black locust & 10 & 5 & 4 & 5 & 6 & 3 & \\
\hline & black birch & 9 & 3 & 7 & 4 & 7 & 4 & \\
\hline & sassafras & 1 & 1 & 6 & 3 & 1 & 1 & \\
\hline total & & 196 & 29 & 117 & 17 & 130 & 19 & \\
\hline Slope Aspect & Species & 1999 TPA & StErr & 2004 TPA & StErr & 2009 TPA & StErr & P-value \\
\hline Southerly & yellow-poplar & 82 & 13 & 68 & 9 & 68 & 9 & \\
\hline \multirow[t]{8}{*}{$n=99$} & oaks & 83 & 7 & 65 & 5 & 61 & 6 & \\
\hline & others & 83 & 4 & 58 & 3 & 40 & 5 & \\
\hline & black cherry & 30 & 5 & 27 & 5 & 22 & 4 & \\
\hline & red maple & 46 & 7 & 35 & 6 & 31 & 5 & \\
\hline & black birch & 33 & 7 & 26 & 6 & 23 & 6 & \\
\hline & sassafras & 56 & 11 & 44 & 9 & 29 & 6 & \\
\hline & black locust & 24 & 6 & 18 & 4 & 15 & 3 & \\
\hline & sugar maple & 11 & 3 & 5 & 1 & 7 & 2 & \\
\hline total & & $448^{\mathrm{a}}$ & 22 & $346^{\mathrm{a}}$ & 16 & $296^{\mathrm{ab}}$ & 13 & $<0.0001$ \\
\hline Slope Aspect & Species & 1999 TPA & StErr & 2004 TPA & StErr & 2009 TPA & StErr & P-value \\
\hline summit & oaks & 207 & 44 & 160 & 33 & 156 & 48 & \\
\hline \multirow[t]{8}{*}{$n=9$} & red maple & 124 & 49 & 84 & 42 & 60 & 29 & \\
\hline & black cherry & 27 & 19 & 80 & 41 & 49 & 32 & \\
\hline & black birch & $433^{\mathrm{a}}$ & 223 & $200^{\mathrm{b}}$ & 110 & $116^{\mathrm{b}}$ & 57 & $\mathrm{P}<0.0001$ \\
\hline & yellow-poplar & 31 & 11 & 27 & 14 & 27 & 10 & \\
\hline & others & 144 & 16 & 56 & 9 & 36 & 9 & \\
\hline & sassafras & 22 & 10 & 18 & 10 & 16 & 8 & \\
\hline & black locust & 22 & 12 & 18 & 10 & 4 & 4 & \\
\hline & sugar maple & 0 & 0 & 0 & 0 & 0 & 0 & \\
\hline total & & $1010^{\mathrm{a}}$ & 249 & $643^{b}$ & 122 & $464^{\mathrm{b}}$ & 54 & $<0.0001$ \\
\hline Slope Aspect & Species & 1999 TPA & StErr & 2004 TPA & StErr & 2009 TPA & StErr & P-value \\
\hline Westerly & oaks & 132 & 9 & 120 & 9 & 105 & 11 & \\
\hline \multirow[t]{8}{*}{$n=48$} & yellow-poplar & 57 & 15 & 46 & 11 & 40 & 10 & \\
\hline & others & 81 & 3 & 60 & 3 & 55 & 2 & \\
\hline & black birch & 135 & 42 & 138 & 40 & 75 & 23 & \\
\hline & red maple & 124 & 23 & 85 & 16 & 64 & 13 & \\
\hline & black cherry & 22 & 8 & 22 & 7 & 19 & 7 & \\
\hline & sugar maple & 3 & 1 & 2 & 1 & 8 & 5 & \\
\hline & sassafras & 37 & 10 & 27 & 9 & 15 & 4 & \\
\hline & black locust & 23 & 17 & 19 & 10 & 10 & 6 & \\
\hline total & & $614^{a}$ & 58 & $519^{\mathrm{a}}$ & 45 & $391^{a b}$ & 30 & 0.0001 \\
\hline
\end{tabular}


aspects from 1999-2009 ( $\mathrm{P}$ < 0.0001). Conversely, densities increased from 2004-2009 on both north and east aspects. Oaks were the most abundant species on summit and westerly sites, ranging between 132-207 trees/acre in 1999 and decreasing to between 105-156 trees/acre in 2009. Black birch ranked second in abundance on both aspects and decreased from 433-116 stems on summit sites $(\mathrm{P}<0.0001)$. Total overstory densities decreased significantly from 19992009 on both summit $(\mathrm{P}<0.0001)$ and westerly aspects $(\mathrm{P}=0.0001)$.

\section{Wild Grapevine Effects on Stand Development}

From 1999 to 2009, the number of stands sustaining grapevine infestations declined from 15 to 11 (Figure 8 ). In 1999, 20.2\% of the overstory was infested, with $6.3 \%$ and $2.1 \%$ of the canopy sustaining evident and irreversible damage, respectively. In 2004, overall infestation decreased to $19.0 \%$ with $5.7 \%$ and $2.5 \%$ of damage in the two most severe categories. In 2009, $18.2 \%$ of dominants and codominants were infested with $6.8 \%$ evident damage and $2.7 \%$ irreversible.

In 2009, significant differences existed between percentages of overstory grapevine infestations on mesic and xeric slope aspects (Figure 9). Vines infested $46 \%$ of the overstory on easterly sites, a significantly higher percentage than both the $12 \%$ infestation on south facing sites $(\mathrm{P}<0.0001)$, and the $5 \%$ canopy infestation in westerly sites $(\mathrm{P}<0.0001)$. North facing sites were $35 \%$ infested in the overstory and were also significantly higher than southerly sites ( $\mathrm{P}=0.0124)$ and westerly sites $(\mathrm{P}=.0061)$. Vines were absent from summit sites. 


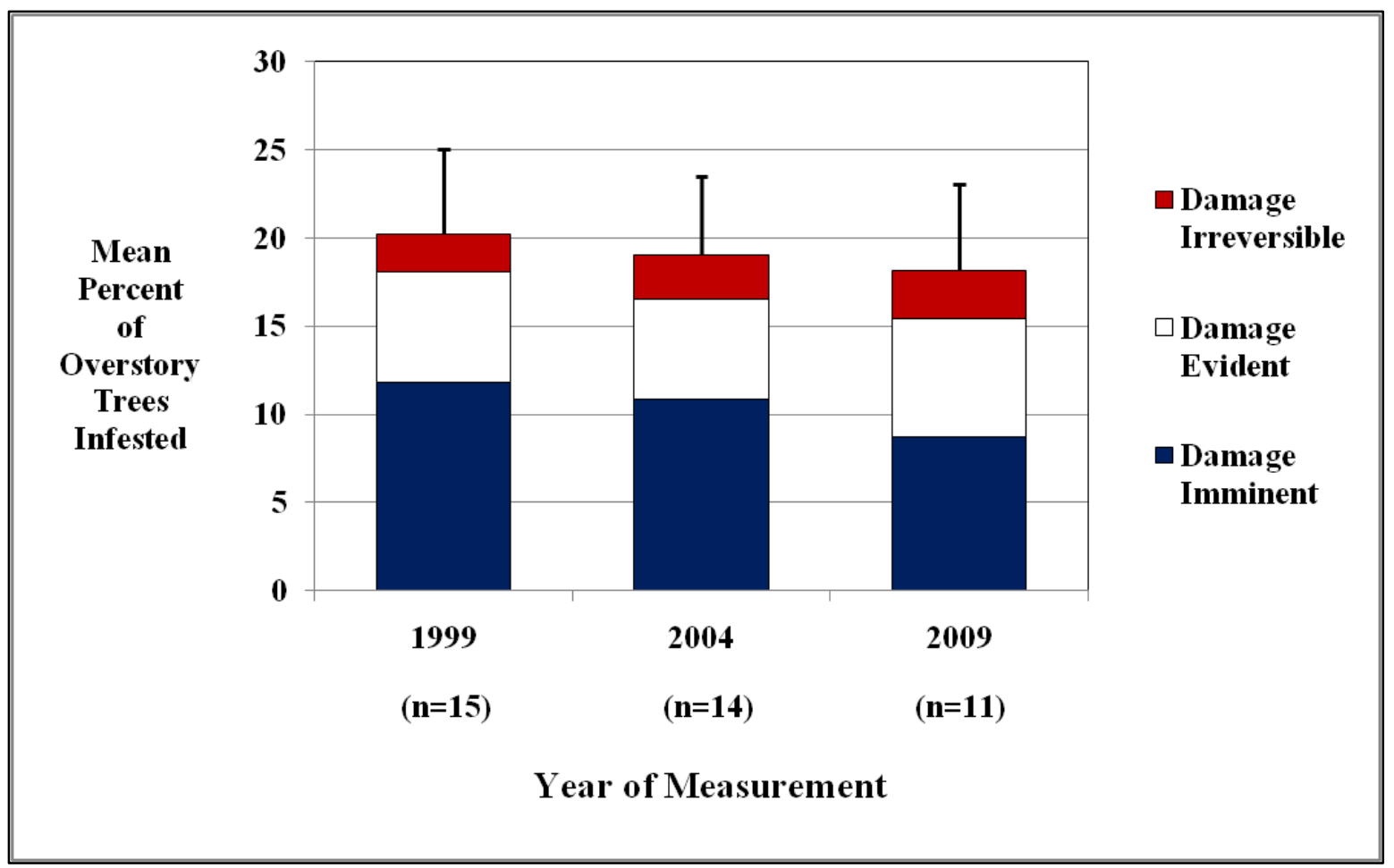

Figure 8. Distribution and relative severity of overstory grapevine infestation for all infested clearcut stands from 1999-2009. No significant differences exist between measurements $(\alpha=0.05)$. 


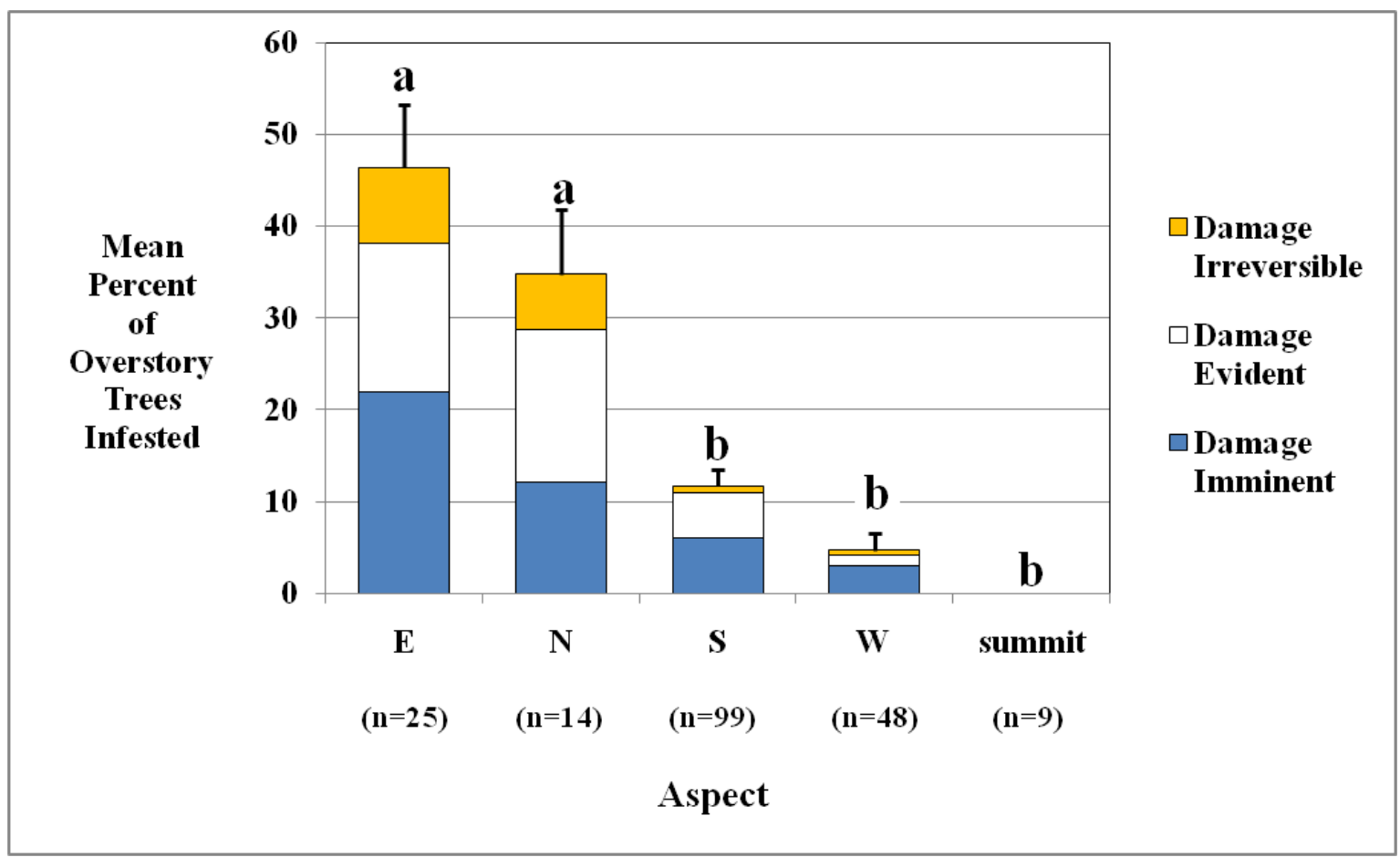

Figure 9. Distribution and relative severity of overstory grapevine infestations among slope aspects in 2009. A change in alphabetical notations indicates a significant difference between infestation levels $(\mathrm{P} \leq 0.05)$. 


\section{DISCUSSION}

Results of this study demonstrated the vigorous regeneration of 15 unmanaged clearcut harvests established between 1970 and 1990. These sites hosted a diverse array of over 40 woody species in 2009. In all stands from 1999-2009, significant increases in basal area coincided with significant decreases in density for both trees $\geq 1$ inch dbh and overstory trees. The utilization of growing space by successively fewer individuals over the study period indicates consistent, unhindered development. This supports the assumptions that growing sites in the Central Appalachians have the inherent capacity to regenerate, and that these stands are representative of successful regeneration (Miller et al. 2001).

In 2009, canopy closure had occurred in the study stands, and they had passed through the stand initiation stage (Oliver and Larson 1996). They are now at various junctures in the stem exclusion stage and the canopy has settled into a hierarchy dominated by yellow-poplar and oaks. Yellow-poplar basal area/acre increased significantly from 1999-2009, while red maple decreased significantly over the same time period. Notable increases of red maple are often considered representative of the increasing importance of fire intolerant species This trend resulted in northeastern forests after the implementation of fire prevention policies in the 1920's (Nowacki and Abrams 2008). This trend does not exist in the study stands.

In the overstory of stands aged $\leq 25$ years, certain species demonstrated silvical attributes that distinguished them from their competitors (Table 4). Yellow-poplar justified its reputation as a fast growing intolerant, occupying the greatest percentage of basal area in the youngest stands, with fewer than half the stems of the most numerous oak group. In contrast, black birch is known to regenerate profusely from seed on open sites, only to rapidly fade by age 20 (Burns 
and Honkala 1990). It was not surprising, then, that in 1999 when stands were aged 9-15 years, birch was by far the most numerous species, and that by 2009 their numbers had plummeted and they had fallen to second place behind oaks. Meanwhile, as birch faltered and growing space was vacated, it appears that sugar maple may have been able to respond. The significant decline in number of black birch between 2004 and 2009 was accompanied by a non-significant increase in density for sugar maple. This occurrence reflects the tendency for sugar maple to be responsive to release, even after being confined in the understory (Barrett 1995).

The analysis of aspect indicated the most productive tree growth occurred on southerly sites, and provided evidence that localized grapevine disturbance was inhibiting tree development on mesic stands. Expectedly, highest stem counts existed on the drier summit and westerly sites, with southerly sites ranking in third place. Mesic sites appeared to be thriving with expected low stem counts attributable to rapid stand development in favorable conditions. However, the basal area/acre analysis clearly indicated that sites on mesic slopes were languishing, as easterly and northerly sites possessed the lowest means. Basal area totals were highest on south facing sites, where significant increases in average basal area/acre coincided with significant decreases in density in all measurements. Given favorable growing conditions, wild grapevines have the potential to reach high concentrations and inhibit stand growth. This had occurred on the mesic study sites.

The analysis of grapevine infestation by aspect demonstrated that overstories on easterly and northerly sites were 46\%, and 35\% infested, respectively (Figure 9). These levels were significantly higher than those in all other aspects. Vines were not a serious threat to stand development on the southerly, westerly, or summit sites, as their levels of infestation were statistically non-significant. 
Grapevine infestations did not worsen with time (Figure 8). From 1999-2009, differences in infestation levels were non-significant in all measurement periods, in all stands combined. This supports the findings of Trimble and Tryon (1979) and Smith (1984) that infestation establishment takes place within an early interval in stand development between harvest and canopy closure. This occurs in approximately 8-10 years on a stand with an oak site index of 70, when the overstory height reaches 15-20 feet (Smith 1989). After canopy closure, the understory shade kills vines that have not succeeded in attaching themselves to a competitively successful tree. Thus vine levels remain fairly constant over the life of the stand. While they can spread rapidly through the canopy once established, they also bring about the demise of their host, and fall to the ground on occasion. Once on the forest floor, vines were no longer recorded in this inventory.

Throughout the mixed mesophytic region of the Appalachian Forest, yellow-poplar is the most significant individual species (Hicks 1997), and there are numerous reasons to expect that it will continue dominate these stands well into the future. In this study, yellow-poplar occupied the greatest percentage of total stand basal area in 2 of 3 age classes, and on 3 of 5 slope aspects. It was also the only species in the study to exhibit a significant increase in percent basal area from 1999-2009.

On favorable sites yellow-poplar is a prolific seed producer with large crops produced almost annually (Burns and Honkala 1990), and seed can remain viable in the soil for over 11 years (Clark and Boyce 1964). Following germination, height increases during the first year range from a few inches to more than a foot. However in full sunlight, rapid height growth begins the second year, and at the end of 5 years heights may reach 10 to 18 feet. An 11-yearold natural seedling 50 feet tall has been recorded (Olson 1969). Yellow-poplar vegetatively 
reproduces from cut stumps, and the sprouts grow more rapidly than seedlings. If yellow-poplar does not establish itself as an overstory tree early in stand development, it is capable of photosynthesizing at or near maximum efficiency when receiving only 3-10\% of full sunlight (Burns and Honkala 1990). These factors combine to enable yellow-poplar to dominate mixed mesophytic stands for periods of over 100 years (Hicks 1997) and have prompted speculation that they are a climax species of the Southern Appalachians (Skeen et al. 1980).

The oak group was dominant in this study in 1 of 3 age classes, and 2 of 5 aspects. Where they were not dominant, they were still very prevalent. However, without species composition data from the previous stands, the reason for their relative abundance is a matter of speculation. Antecedent stands were second growth, and contained three age groups: post logging residuals, the first cohort of regeneration, and the second cohort of regeneration that developed following the death of the American chestnut (Miller et al. 2001). Perhaps viable stumps of the youngest cohort of oaks produced vigorous, fast growing sprouts that were competitive during early formation of these stands. Perhaps harvest protocol requiring the retention of all stems $\leq 2$ inch dbh included sufficient oak regeneration to provide an early competitive advantage. Whatever the underlying reason for the current oak distribution on these stands, these present clearcuts are not likely the silvical equals of the previous stands, and would likely yield different results.

Results obtained in the analysis of aspect revealed a divergent distribution of yellowpoplar and oaks. In both the stand level and age class analyses of stand development, the two were juxtaposed as closely associated dominant species in the canopy. Yellow-poplar had marginally accounted for more basal area, while oaks had often accounted for more stems/acre. However, in 2009 yellow-poplar was shown to dominate more favorable mesic and south facing sites by substantial margins, while oaks were more important on drier summit and westerly sites. 
Also noteworthy was an increased presence of sugar maple in canopies of mesic aspects. Sugar maple is associated with moist fertile sites, and has been cited as the most dominant species in other local studies on mesic stands on the FEF (Schuler and Gillespie 2000). In 2009 maple showed a moderate presence on eastern slopes, was declining on northerly sites, and does not appear capable of competing successfully with yellow-poplar in the near future. 


\section{MANAGEMENT IMPLICATIONS}

Vine control measures should be focused on north and east facing sites. Five years ago, U.S. Forest Service personnel began control treatments, severing vines beneath the closed canopy. However, considerable damage had already occurred on older mesic sites, and recovery will be gradual. Restoring a severely infested site is time consuming, and often requires multiple visits. Going forward, the best strategy would be to contain "grape arbors” that have established beneath canopy openings. All vines that are in trees along the forest/grape arbor interface should receive herbicide treatments. Herbicide will be more reliable than cutting, since vines along a canopy opening will be in at least partial sunlight, and will re-sprout if severed. If treatments are applied in combination with frilling or severing vines, they must be applied in early spring or fall, when grapevine sap is not flowing (Smith 1984).

A land manager may not have sufficient resources to conduct vine treatments necessary for mesic sites to approach their timber potential. Smith (1989) estimated that it would take one man 2.2/hrs to sever100 grapevines/acre in a mature stand, and 1.2 hrs to do the same in a sapling stand. For an herbicide treatment, one man can spray 100 grapevines/acre using 1 gallon of herbicide in one hour. Implications of stand size and hourly rate notwithstanding, it may be sensible to focus efforts on sites occupying southerly aspects. Growing conditions on these sites were conducive to the best basal area growth observed on the study stands, yet they sustained only a $12 \%$ grapevine infestation, half of which was rated as non-threatening (Figure 9). Smith (1989) suggested that a tolerable infestation level in the overstory was 6\% for stands on which growing quality timber was the objective. Reducing the infestation levels to reach this goal could be met with reasonable effort on south aspects. 
The analysis of stand development by age class revealed the duration of vigorous stand development following harvest, and also indicated disturbance. Rapid and significant stand development was observed for all trees $\geq 1$ inch dbh in the two youngest age groups, and included stands of up to 30 years of age. However from 2004-2009, in stands >35 years old there was an interruption in density dependent mortality (Table 4). Smith and Lamson (1986) concluded that at maturity, a stand will consist of 50-75 codominant stems per acre. These stands are only 36-39 years old, yet their density remains fixed at 186-187 overstory trees/acre. The failure of overstory trees to claim growing space during this interval was likely due to both moderate growth rates attributable to age and an inhibition of photosynthesis caused by grapevines that were established on mesic aspects. Recognizing that development has slowed in a stand is useful for planning crop tree management treatments. When growing space is no longer being claimed, a crop tree release can be performed to remove less desirable trees and/or vines from the stand, and provide desirable specimens with more space in which to continue their development.

The abundance of oaks that regenerated on these study stands should be considered a boon. If it is desired that the next stand contain as many oaks, then measures to encourage the development of advance regeneration will be necessary. If advance regeneration establishment is successful, prevailing social attitude likely eliminates fire as the next logical step that could reduce the number of competitive species in the stand. In other clearcut studies performed on the FEF, the percentages of oaks are inferior to those observed in this study (Schuler and Gillespie 2000, Brashears et al. 2004, Gilliam et al. 1995). Stands in the Fernow studies were similar in age and topography to the stands in this study, and in separate cases, oaks were displaced by either yellow-poplar or sugar maple. 


\section{BIBLIOGRAPHY}

Barrett, J.W. 1995. Regional Silviculture of the United States. Third Edition. New York, NY. John Wiley and Sons, Inc. ISBN 0-471-59817-8. 643 p.

Berman, G. M.; Conley-Spencer,M.; Howe, B. J.; Lattea, C. 1992. The Monongahela National Forest 1915-1990. Morgantown, W.Va.: West Virginia University, Public History Program, report prepared for the U.S.D.A. Forest Service.

Boring, L.R.; Monk, C.D.; Swank, W.T. 1981. Early regeneration of a clearcut Southern Appalachian forest. Ecology. 62(5): 1244-1253.

Bost, S. 2001. SP277-J-Black rot of grape. The University of Tennessee Agricultural Extension Service. This work is archived at Trace: Tennessee Research and Creative Exchange.http://trace.tennessee.edu/utk agexdise/43

Brashears, M.B.; Fajvan, M.A.; Schuler, T.M. 2004. An assessment of canopy stratification and tree species diversity following clearcutting in Central Appalachian hardwoods. Forest Science. 50 (1): 54-64.

Brooks, F.E. 1918. Papers on deciduous-fruit insects. I. The grape curculio. II. The grape rootborer. U.S.D.A. Bureau of Entomology. Bulletin No. 730. 19 p.

Burns, R.M.; Honkala, B.H. Tech. Coords. 1990. Silvics of North America: 1. Conifers; 2. Hardwoods. Agriculture Handbook 654. U.S. D.A. Forest Service, Washington, D.C. 2: 877 p.

Carey, J.H. 1994. Vitis aestivalis. In: Fire Effects Information System, [Online]. U.S. D.A. Forest Service, Rocky Mountain Research Station, Fire Sciences Laboratory (Producer). Available: http://www.fs.fed.us/database/feis/

Clark, B.F.; Boyce, S.G. 1964. Yellow-poplar seed remains viable in the forest litter. Journal of Forestry. 62(8): 564-567.

Conrad, D.E. 1997. Excerpt from "The Land We Cared For... A History of the Forest Service's Eastern Region. Fifth edition. Jay H. Cravens, George Banzhaf \& Company. Milwaukee, WI. http://www.foresthistory.org/ASPNET/Publications/region/9/history/chap15.aspx.

Dale, M.E.; Smith, H.C.; and Pearcy, J.N. 1994. Size of clearcut opening affects species composition, growth rate, and stand characteristics. Res. Pap. NE-698. Radnor, PA: U.S.D.A. Forest Service, Northeastern Forest Experiment Station. 21 p.

Della Bianca, L. 1978. Characteristics, habitat, and fruiting of wild grapevines in the southern appalachians. Journal Elisha Mitchell Science Society. 94: 21-26. 
Della Bianca, L.; Beck, D.E. 1985. Selection management in Southern Appalachian hardwoods. Southern Journal of Applied Forestry. 9(3): 191-196.

Fairfax, S.K.; Achterman, G.L. 1977. The Monongahela controversy and the political process. Journal of Forestry. 75(8): 485-487.

Gilliam, F.S.; Turrill, N.L.; Adams, M.B. 1995. Herbaceous-layer and overstory species in clearcut and mature Central Appalachian hardwood forests. Ecological Applications. 5(4): 947955.

Hicks, R.R., Jr. 1997. Humans and fire: A history of the Central Appalachian hardwoods. Proceedings: Workshop on fire, people, and the Central Hardwood landscape. GTR -NE-274.

Lamson, N.I.; Smith, H.C. 1991. Stand development and yields of Appalachian hardwood stands managed with single tree selection for at least 30 years. Research Paper NE-665. Radnor, PA. U.S.D.A Forest Service Northeastern Forest Experiment Station. 6p.

Lennox, A.T. 2001. Fact Sheet: Wild Grape. Penn State College of Agricultural Sciences School of Forest Resources. http://rnrext.cas.psu.edu/PDFs/grape.PDF

McKim, C. R. 1970. 50 year history of the Monongahela National Forest. Unknown Journal Title, Unknown Volume. Retreived from http://www.biomedsearch.com/sci/50-year-historyMonongahela-National/0000477554.html

Miller, G. W.; Kochenderfer, J.N. 1998. Maintaining species diversity in the Central Appalachians. Journal of Forestry. 96(7): 28-33.

Miller, G.W.; Kochenderfer, J.N.; Knibbs, J.; Baumgras, J. E. 2001. Vegetative conditions and management options in even-age stands on the Monongahela National Forest. In Barras, Stan J., 2001. Proceedings: National Silvicultural Workshop; 1999 Oct. 5-7; Kalispell MT. Proc. RNRSP-00. Ogden UT; U.S.D.A. Forest Service, Rocky Mountain Research Station.

Morrissey, R.C.; Gauthier M.M.; Kershaw, Jr., J.A.; Jacobs, D.F., Seifert, J.R., Fischer, B.C. 2009. Grapevine (Vitis spp.) dynamics in association with manual tending, physiography, and host tree associations in temperate deciduous forests. Forest Ecology and Management. 257(8): 1839-1846.

Mountford, M.D. 1961. On E.C. Pielou's index of non-randomness. Journal of Ecology. 49(2): 271-275.

Nowacki, G.J.; Abrams, M.D. 2008. The demise of fire and "mesophication" of forests in the eastern United States. BioScience. 58(2): 1223-1238.

Oliver, C.D.; Larson, B.C. Forest Stand Dynamics. Update Edition. New York, NY. 1996. ISBN 0-471-13833-9. $521 \mathrm{p}$. 
Olson, D. F. , Jr. 1969. The silvical characteristics of yellow-poplar. USDA, Forest Service. U.S.D.A. Forest Service Research Paper SE-48. February.

Open Jurist. Online citation: (http://openjurist.org/522/f2d/945/west-virginia-division-of-izaakwalton-league-of-america-inc-v-l-butz)

Schuler, T.M.; Gillespie, A.R. 2000. Temporal patterns of woody species diversity in a Central Appalachian forest from 1856 to 1997. Journal of the Torrey Botanical Society. 127(2): 149-161.

Shands, W.E. 1992. The Lands Nobody Wanted: The Legacy of Eastern National Forests. In: The Origins of National Forests. H.K. Steen ed. Forest History Society. Durham. NC.

Shutts, L.M. 1968. Autoecology and fruit production of summer grape (Vitis aestivalis) and

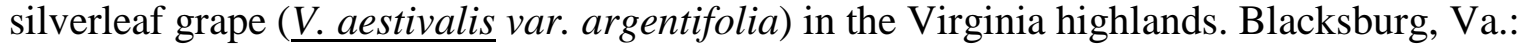
Virginia Polytechnic Institute. 55p. M.S. thesis.

Skeen, J.N.; Carter, M.E.B.; Ragsdale, H.L. 1980. Yellow-poplar: The piedmont case. Bulletin of the Torrey Botanical Club. 107(1): 1-6.

Smith, D.M.; Larson, B.C.; Kielty, M.J.; Ashton, P.M.S. 1997. The Practice of Silviculture. Applied Forest Ecology. Ninth Edition. John Wiley and Sons, Inc. 537 p.

Smith, H.C. 1981. Diameters of clearcut openings influence Central Appalachian hardwood stem development - a ten year study. U.S.D.A. Forest Service. Research Paper NE-476. 8 p.

Smith, H.C. 1984. Forest management guidelines for controlling wild grapevines. U.S.D.A. Forest Service. Research Paper NE-548. 15 p.

Smith, H.C. 1989. U.S.D.A. Forest Service. Central Hardwood Notes. Wild grapevine management http://www.treesearch.fs.fed.us/pubs/18610

Smith, H.C.; Lamson, N.I. 1986. Cultural practices in Appalachian hardwood stands - if done, how to do them. In: Smith, H.C., Eye, M.C., eds. Proceedings: guidelines for managing immature Appalachian hardwood stands. SAF Publ. 86-02. Morgantown, WV: West Virginia University books: 46-61.

Smith, H.C.; McCay, R.E. 1979. Estimating time required to cut grapevines in young, even-aged hardwood stands. Southern Journal of Applied Forestry. 3(3): 125-127.

Smith, H.C.; Smithson, P.M. 1975. Cost of cutting grapevines before logging. U.S.D.A. Forest Service. Northeastern Forest Experiment Station. Upper Darby, PA. Research Note NE-207. 4 p.

Staff Writer. 1976. Lumber: No Clear Cut Decision for Timber. Time 107 (20) May 17. http://www.time.com/time/magazine/article/0,9171,945618,00.html 
Steelman, T.A.; Ascher, W. 1997. Public involvement methods in natural resource policy making: Advantages, disadvantages and trade-offs. Policy Sciences. 30: 71-90.

Steelman, T. A. 2007. The Monongahela controversy and decision. In Forests and forestry in the Americas: an encyclopedia. http://wiki.safnet.org/index.php?title=Currentissues09\&redirect=no

Trimble, G.R. 1972. Reproduction seven years after seed tree harvest cutting in Appalachian hardwoods. U.S.D.A. Forest Service Northeastern Forest Experiment Station. Upper Darby, PA. Research Paper NE-223. 19 p.

Trimble, G.R. 1973. The regeneration of Central Appalachian hardwoods with emphasis on the effects of site quality and harvesting practice. U.S.D.A. Forest Service Research Note SE-282. $14 \mathrm{p}$.

Trimble, G.R., Jr.; Hart, G. 1961. An appraisal of early reproduction after cutting in Northern Appalachian hardwood stands. U.S.D.A. Forest Service. Northeastern Forest Experiment Station. Upper Darby Pa. Station Paper no. 162. 25 p.

Trimble, G.R.; Tryon, E.H. 1979. Silvicultural control of wild grapevines. Morgantown, WV. West Virginia University Agricultural Forest Experiment Station bulletin no.667. 19 p.

U.S.D.A. Forest Service. Monongahela National Forest. Date Unknown. http://www.fs.usda.gov/wps/portal/fsinternet/!ut/p/c4/04_SB8K8xLLM9MSSzPy8xBz9CP0os3g jAwhwtDDw9_AI8zPwhQoY6BdkOyoCAPkATlA!/?ss=110921\&navtype=BROWSEBYSUBJ ECT\&cid=FSE_003840\&navid=170000000000000\&pnavid=null\&position=BROWSEBYSUBJ ECT\&ttype $=$ main\&pname $=$ Monongahela\%2520National\%2520Forest\%2520About\%2520the\%2520Forest

Wendel, G.W.; Trimble, Jr. G.R. 1968. Early reproduction after seed tree harvests in Appalachian hardwoods. U.S.D.A. Forest Service Northeastern Forest Experiment Station. Upper Darby, PA. Research Paper NE-99. 16 p.

Williams, G.W. 2007. The Forest Service Fighting for Public Lands. Understanding Our Government. Westport, CT. Greenwood Press. ISSN 1556-8512. 459 p. 


\section{APPENDIX:}

Plot photographs in 2009 capturing upslope, downslope, lateral, and canopy views. Series includes five plots for each aspect. 

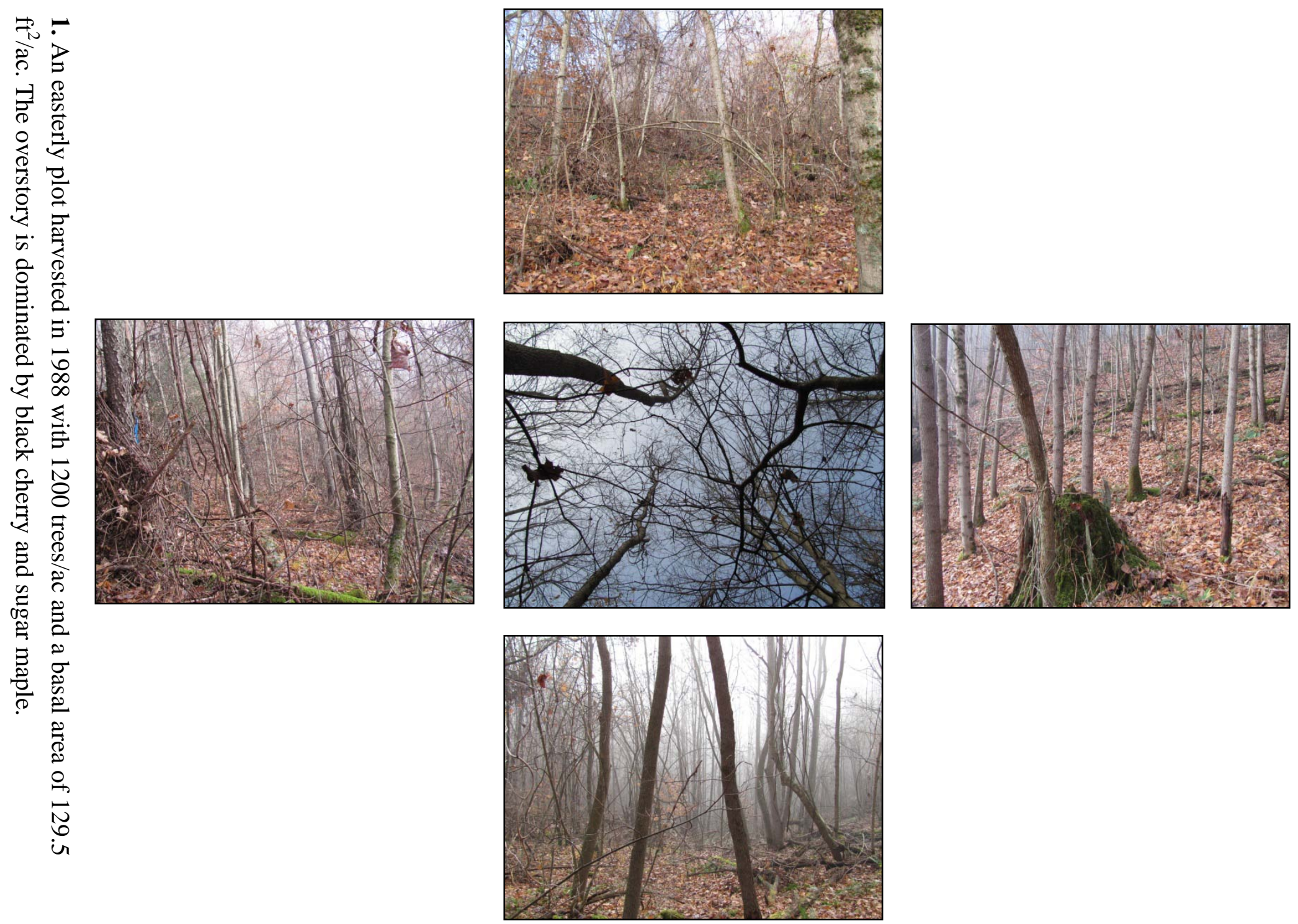

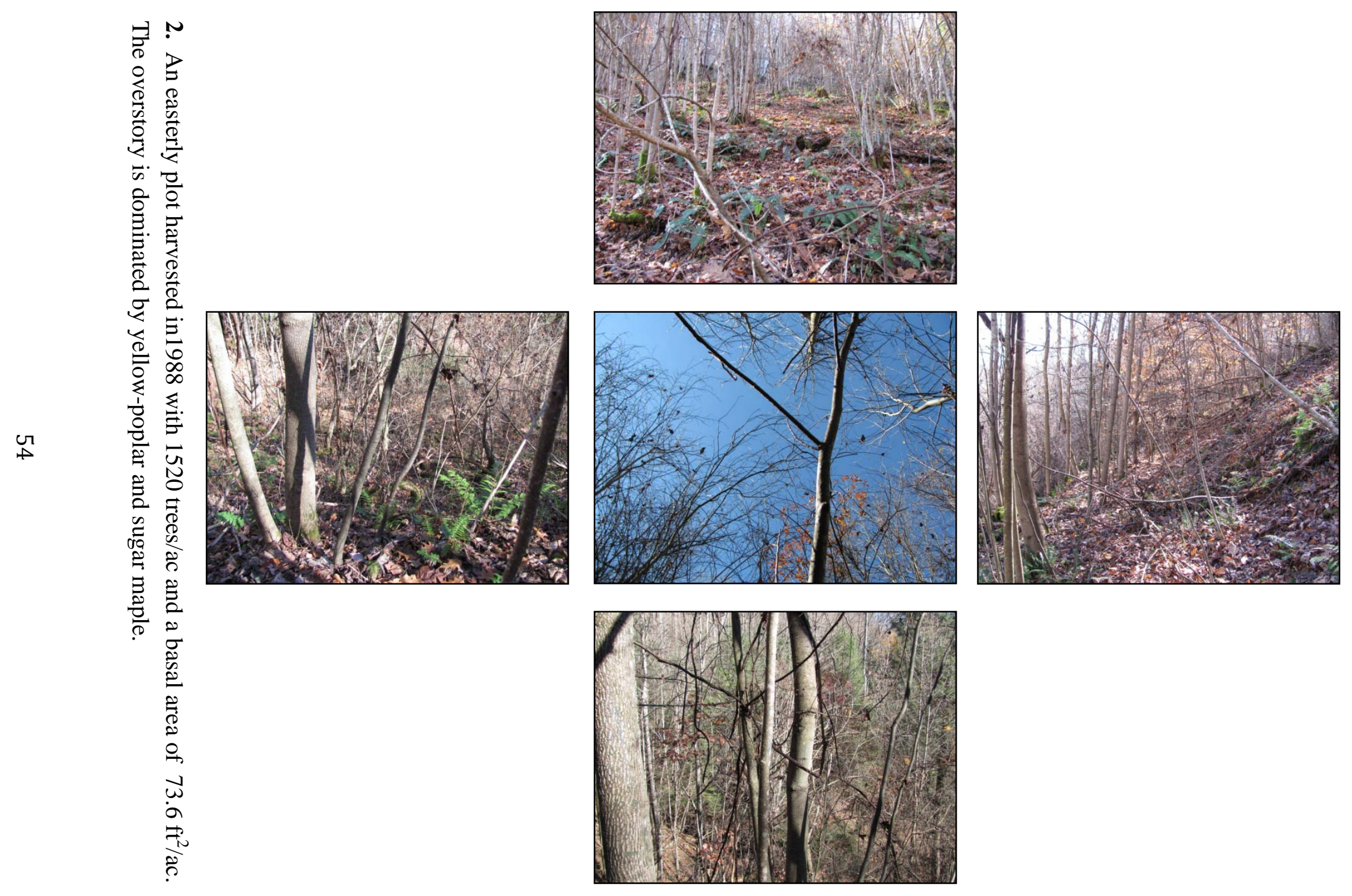

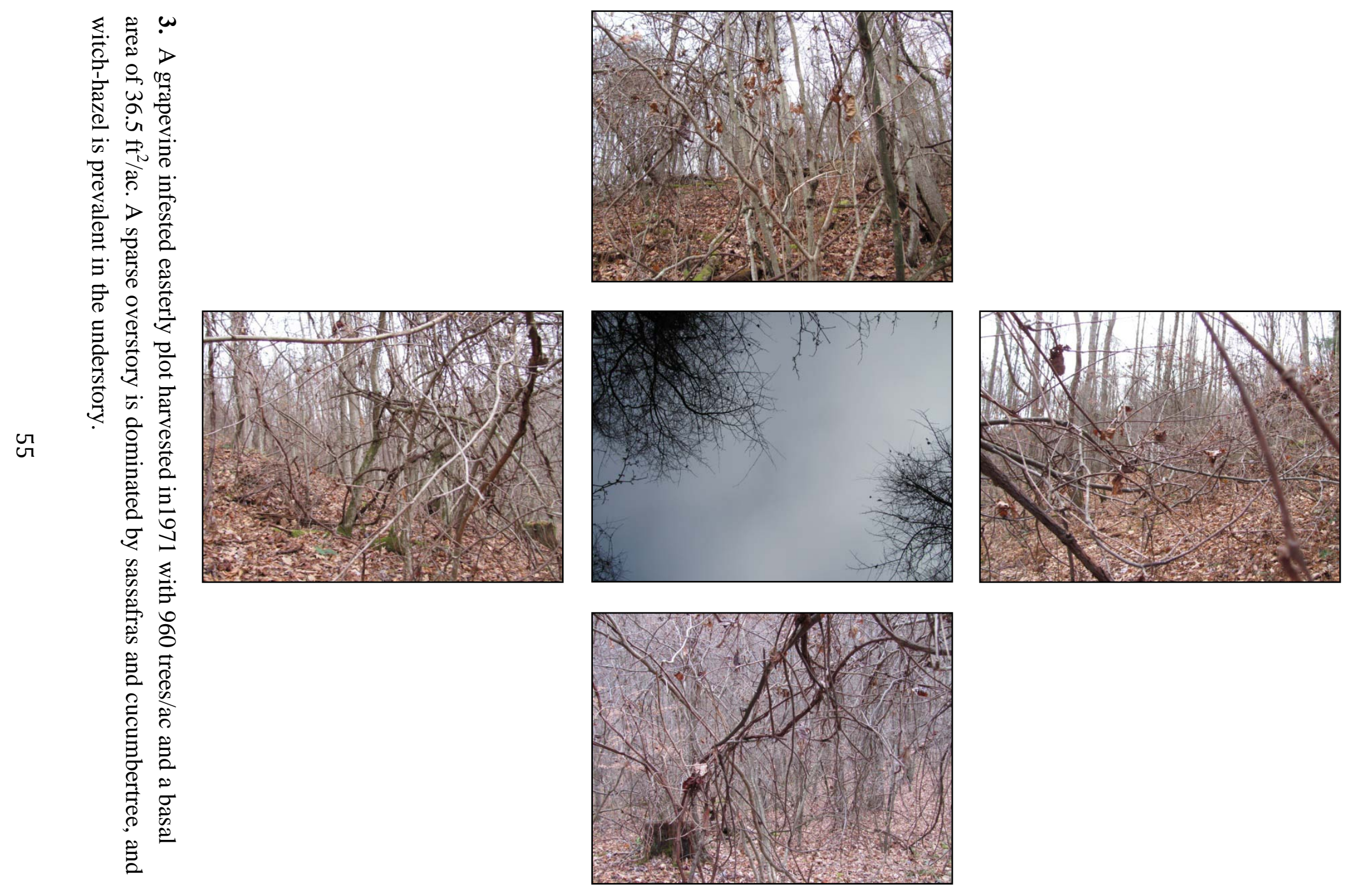


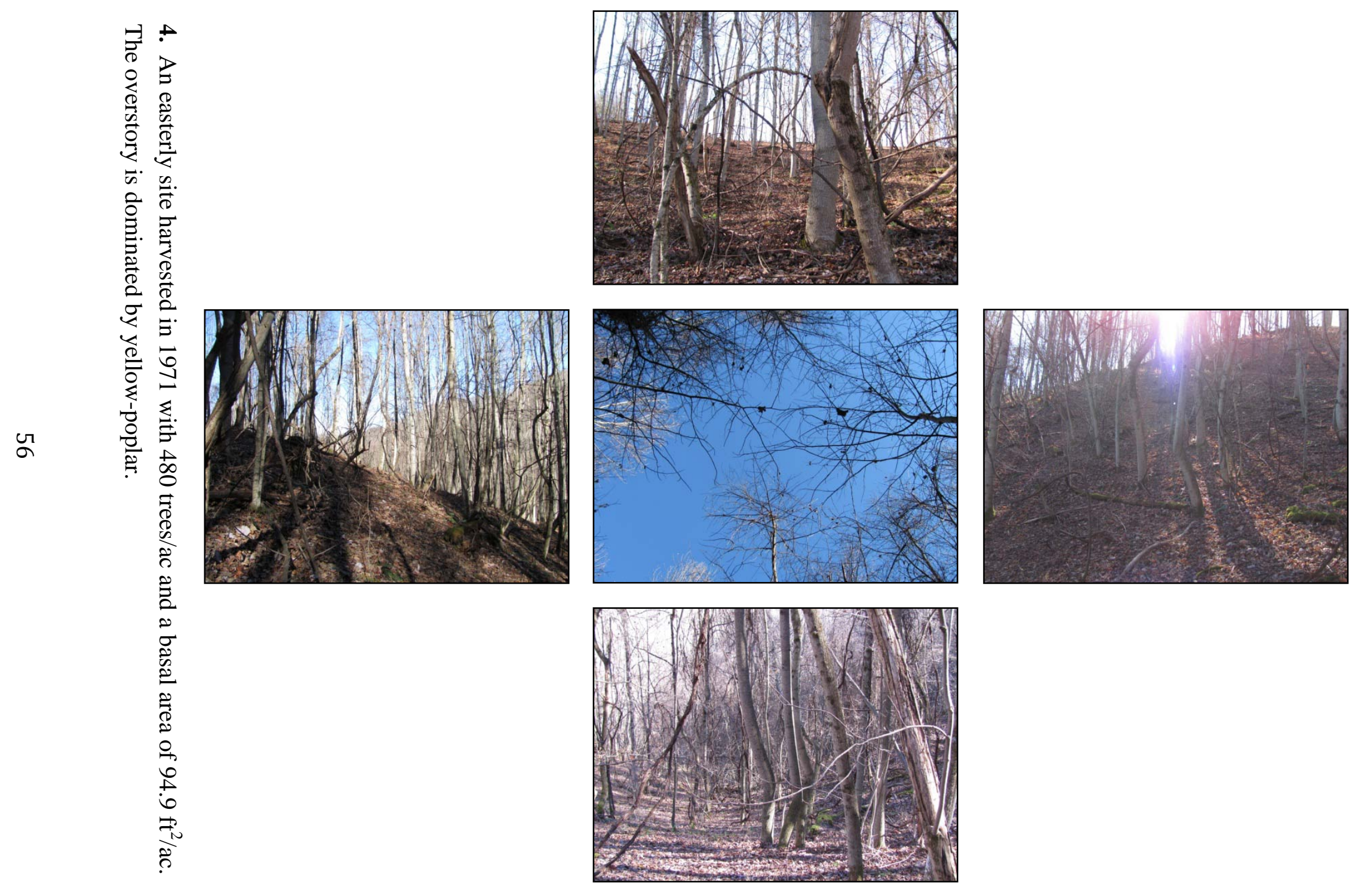



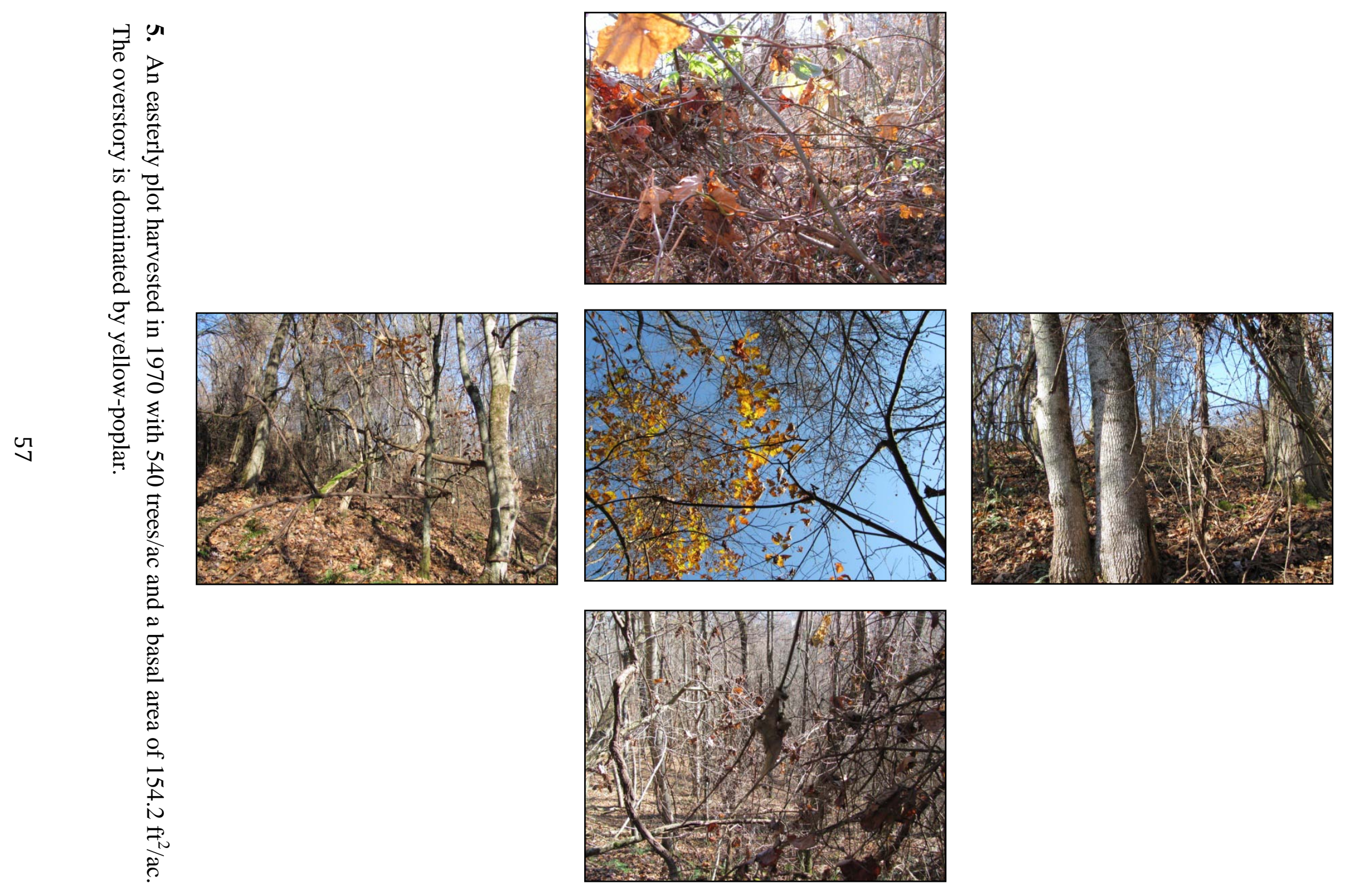

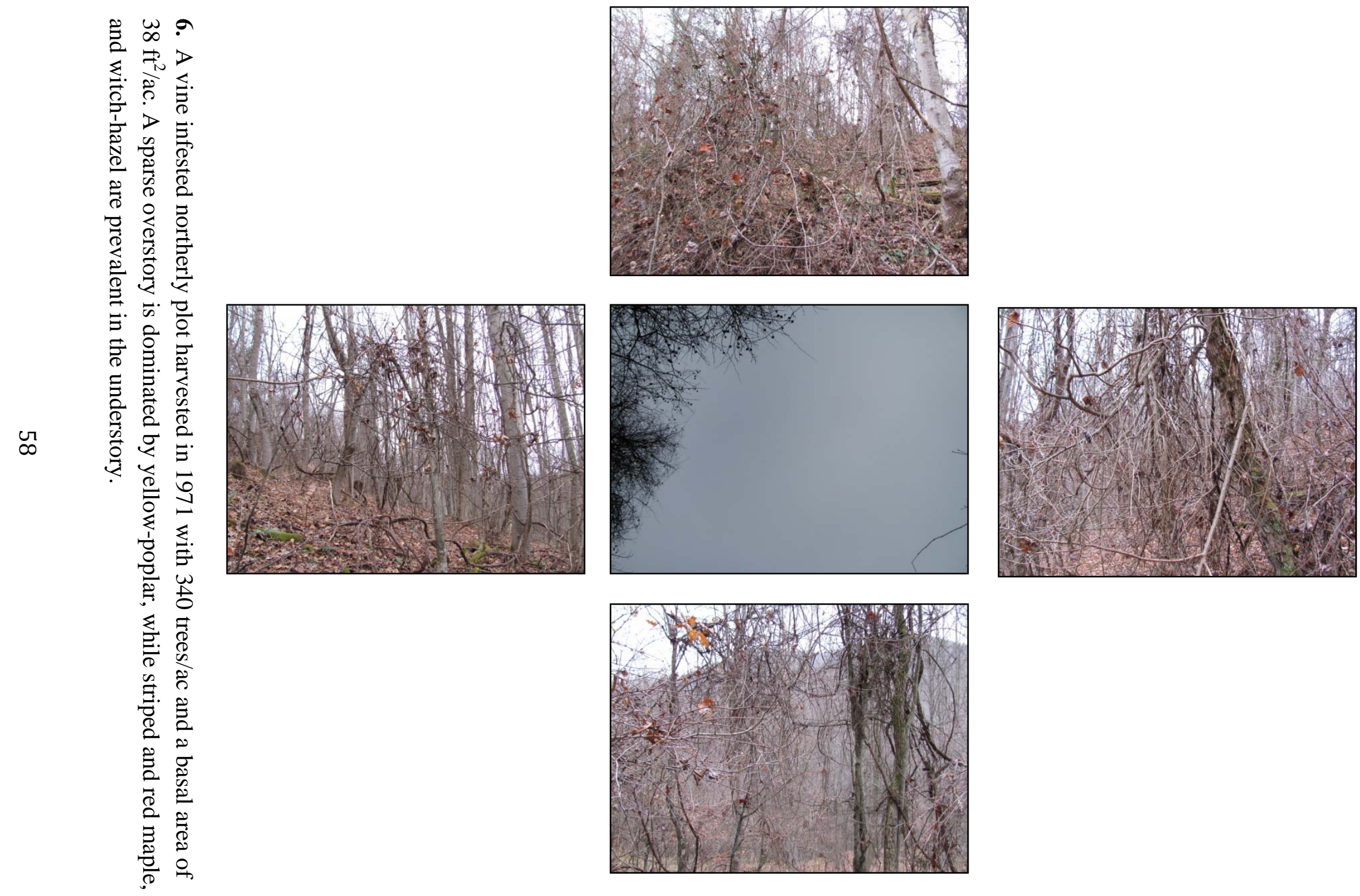

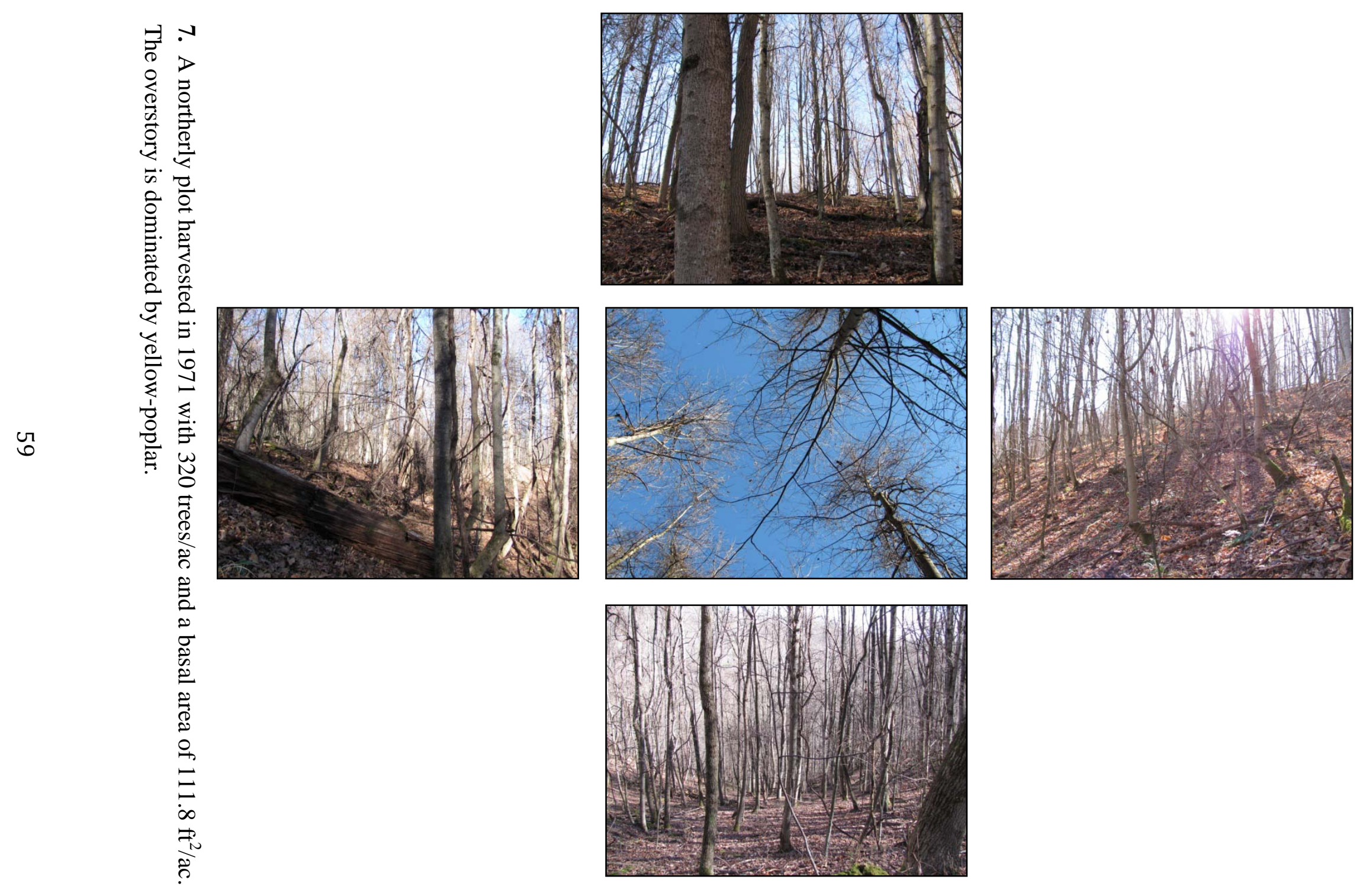


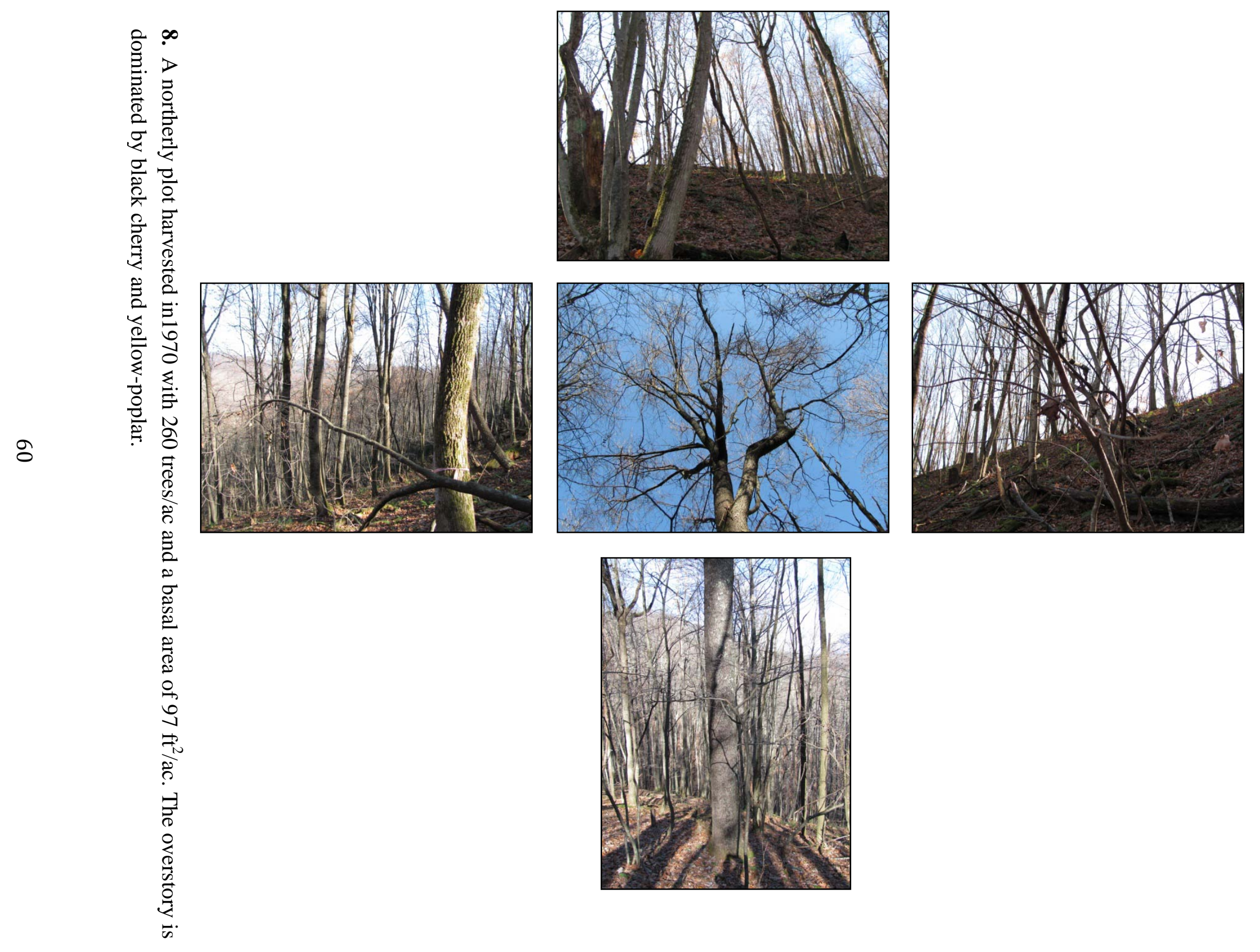



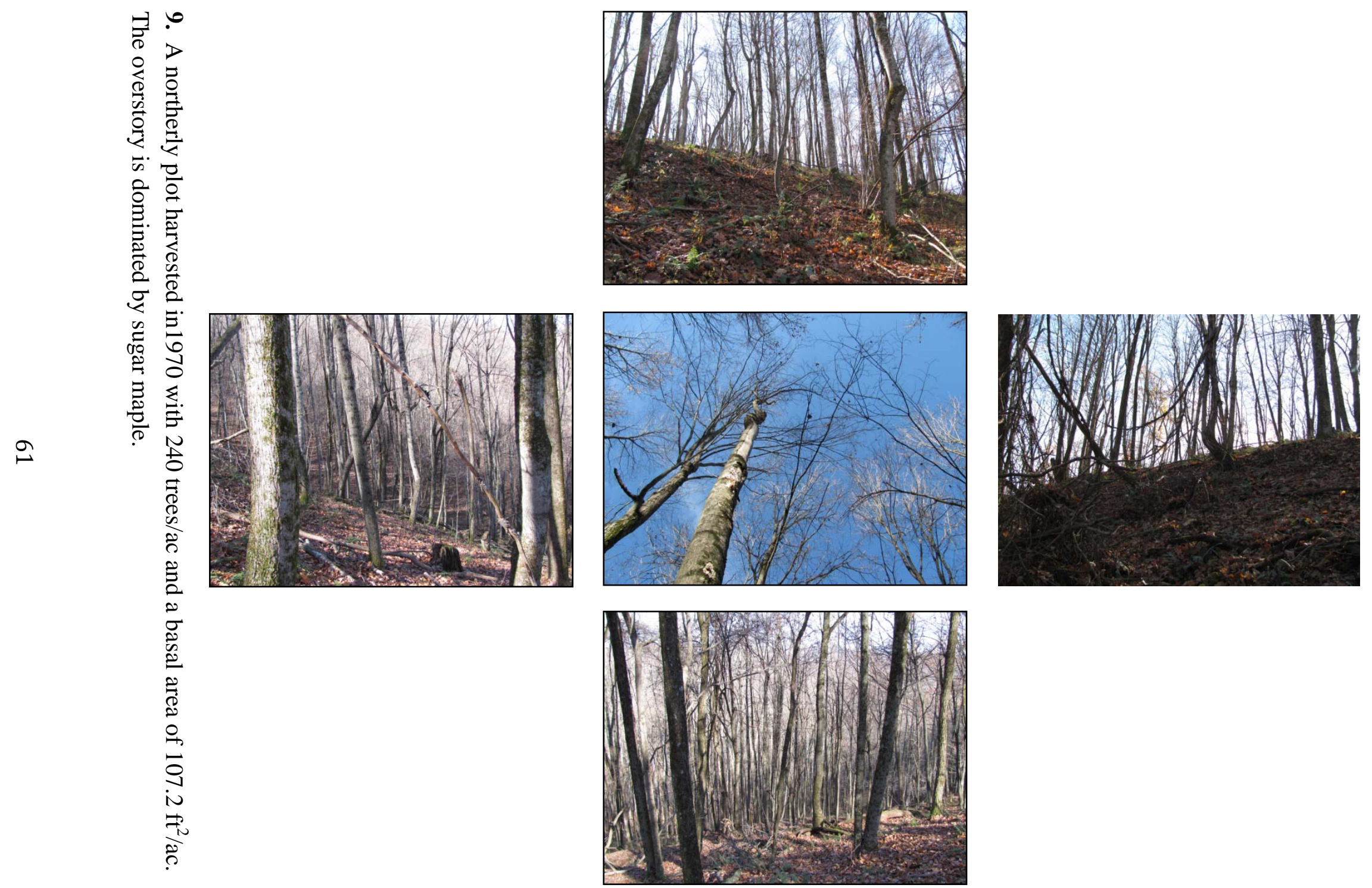

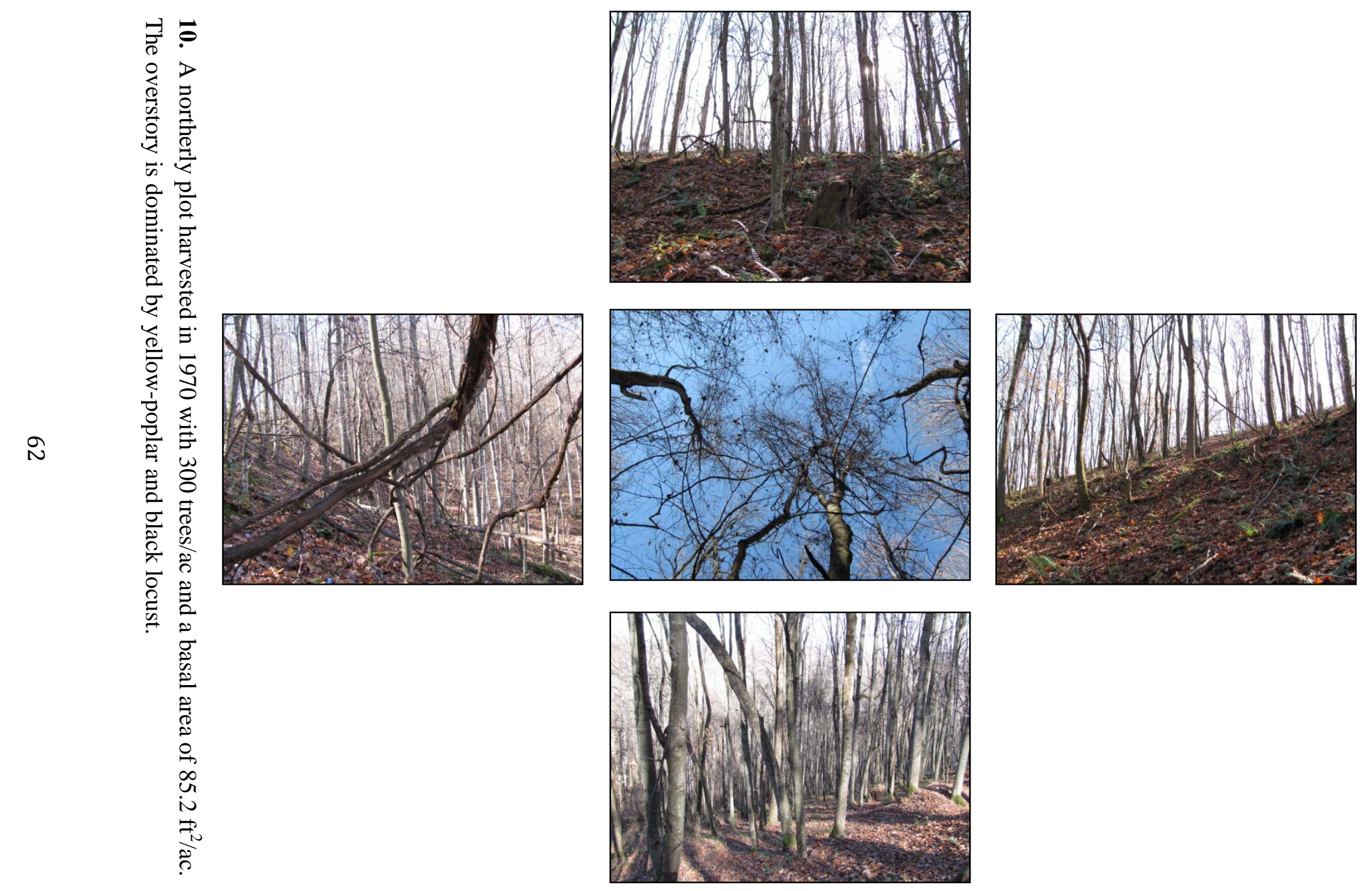

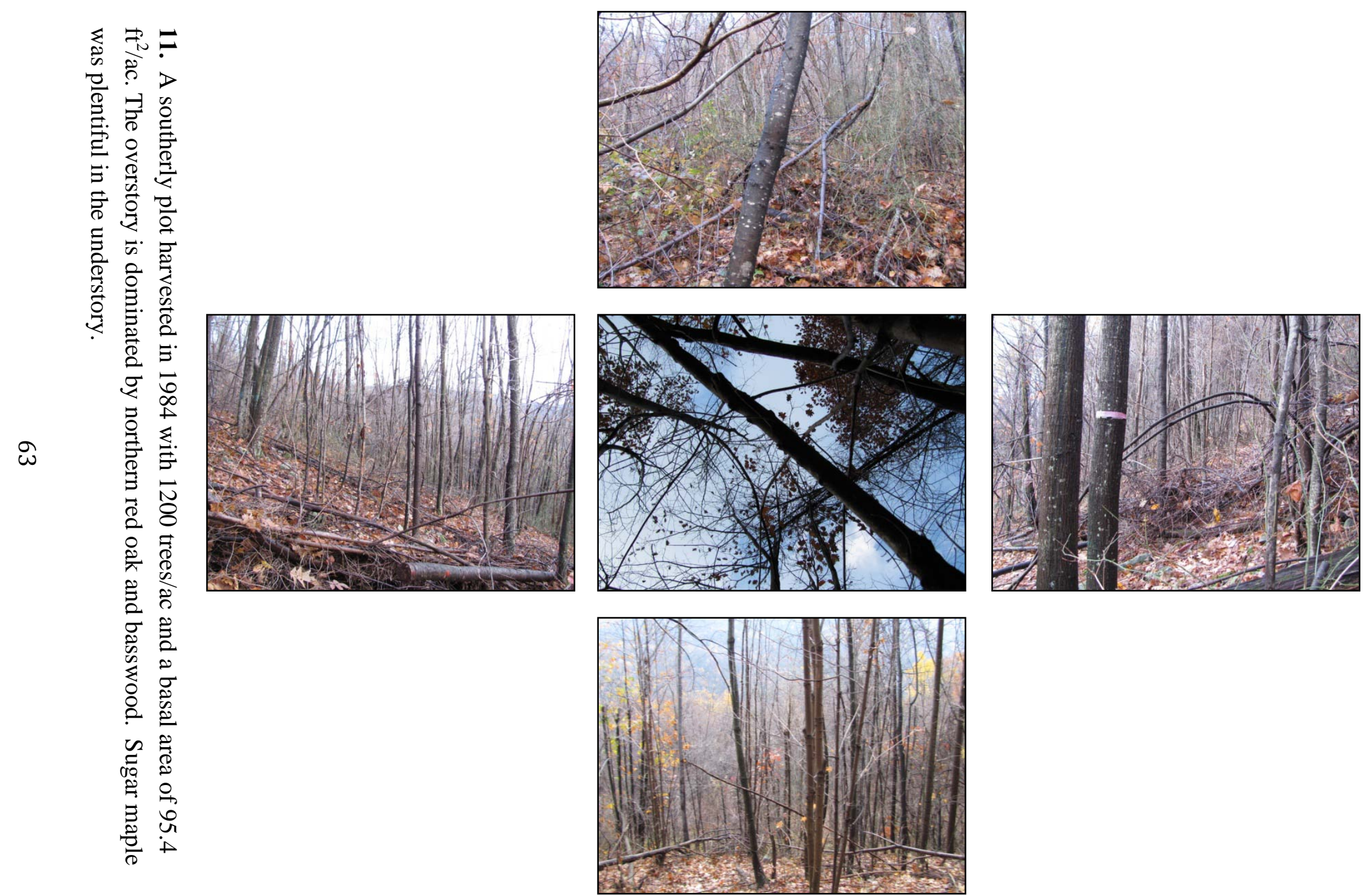


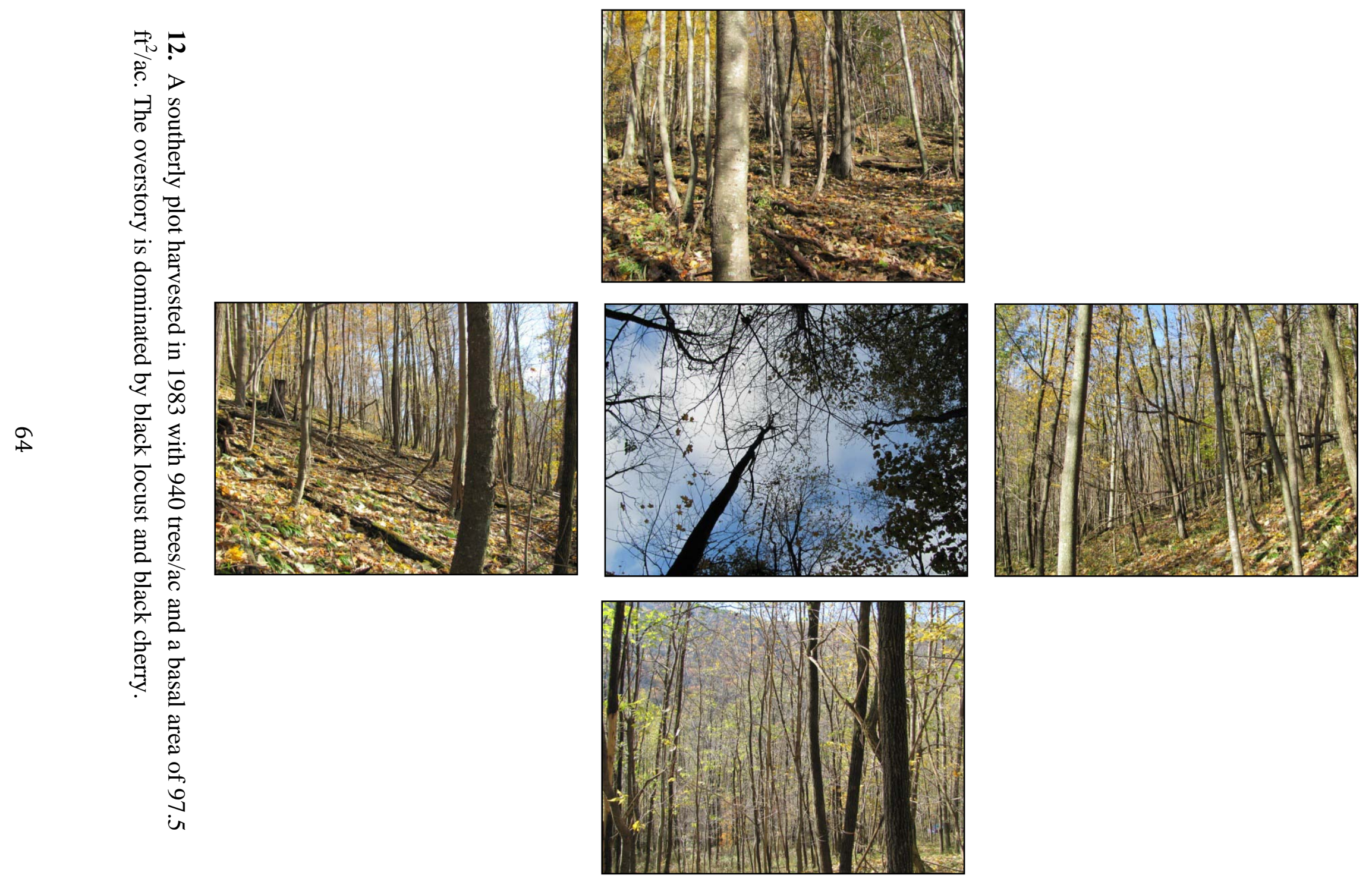



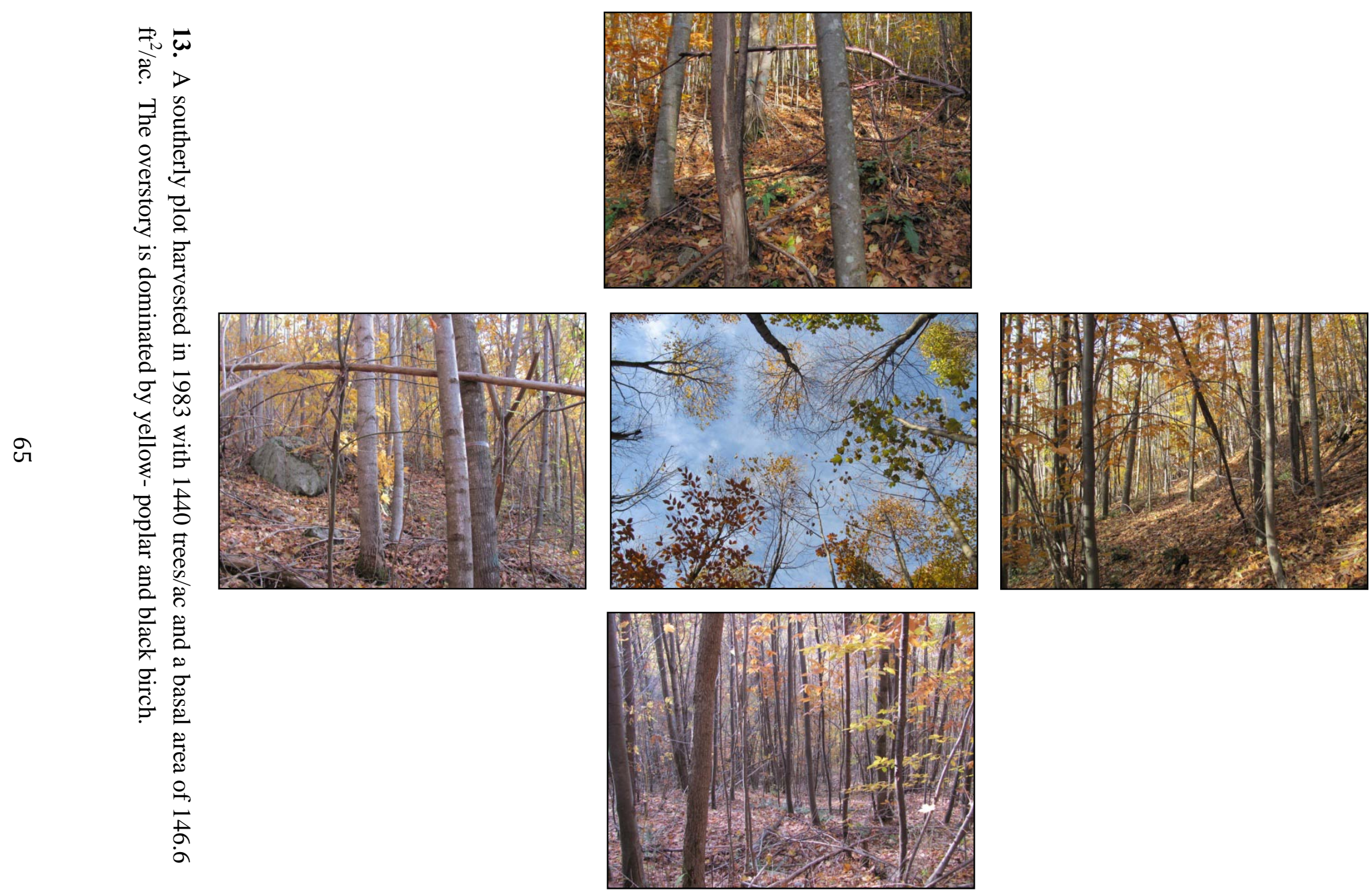

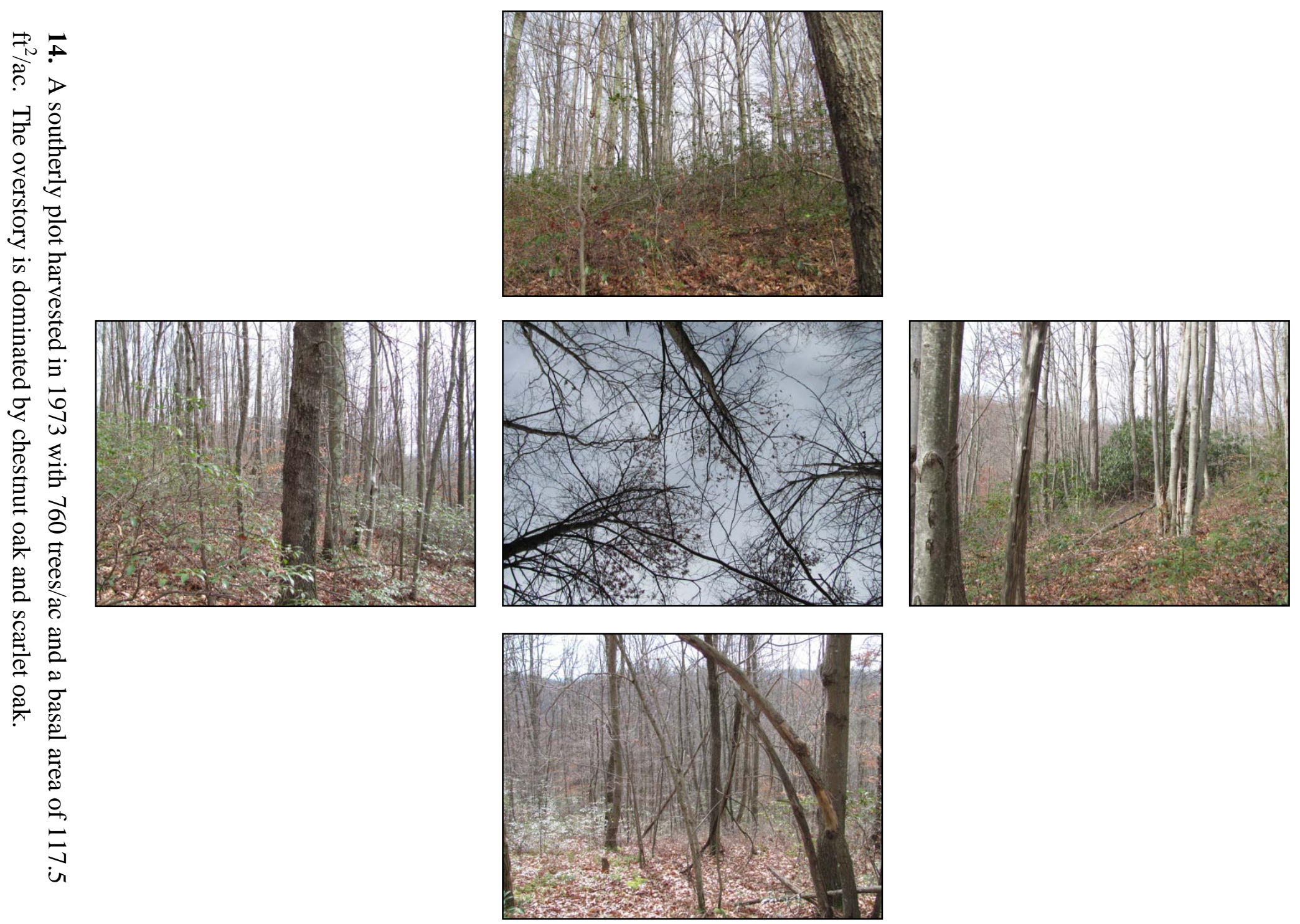

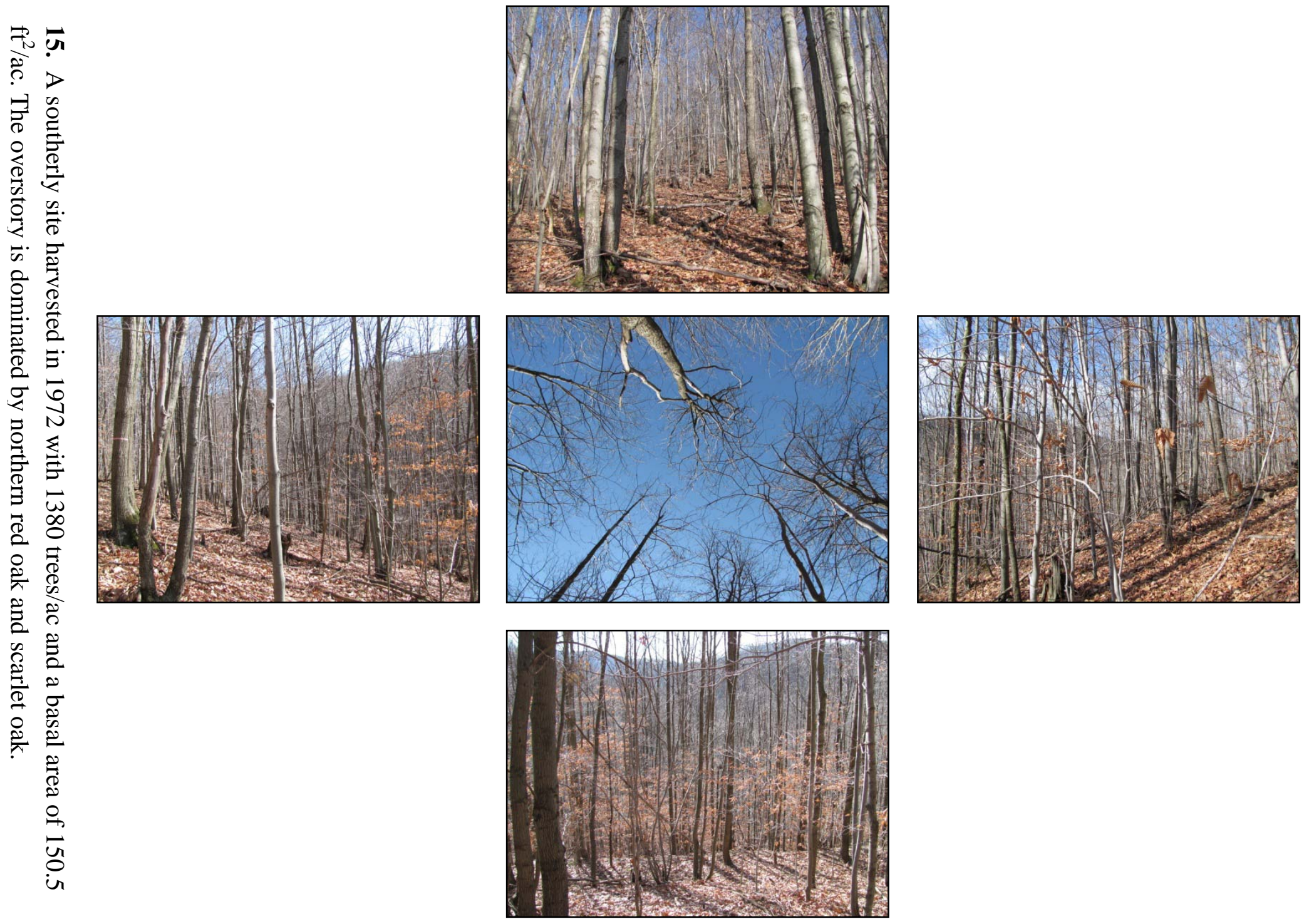

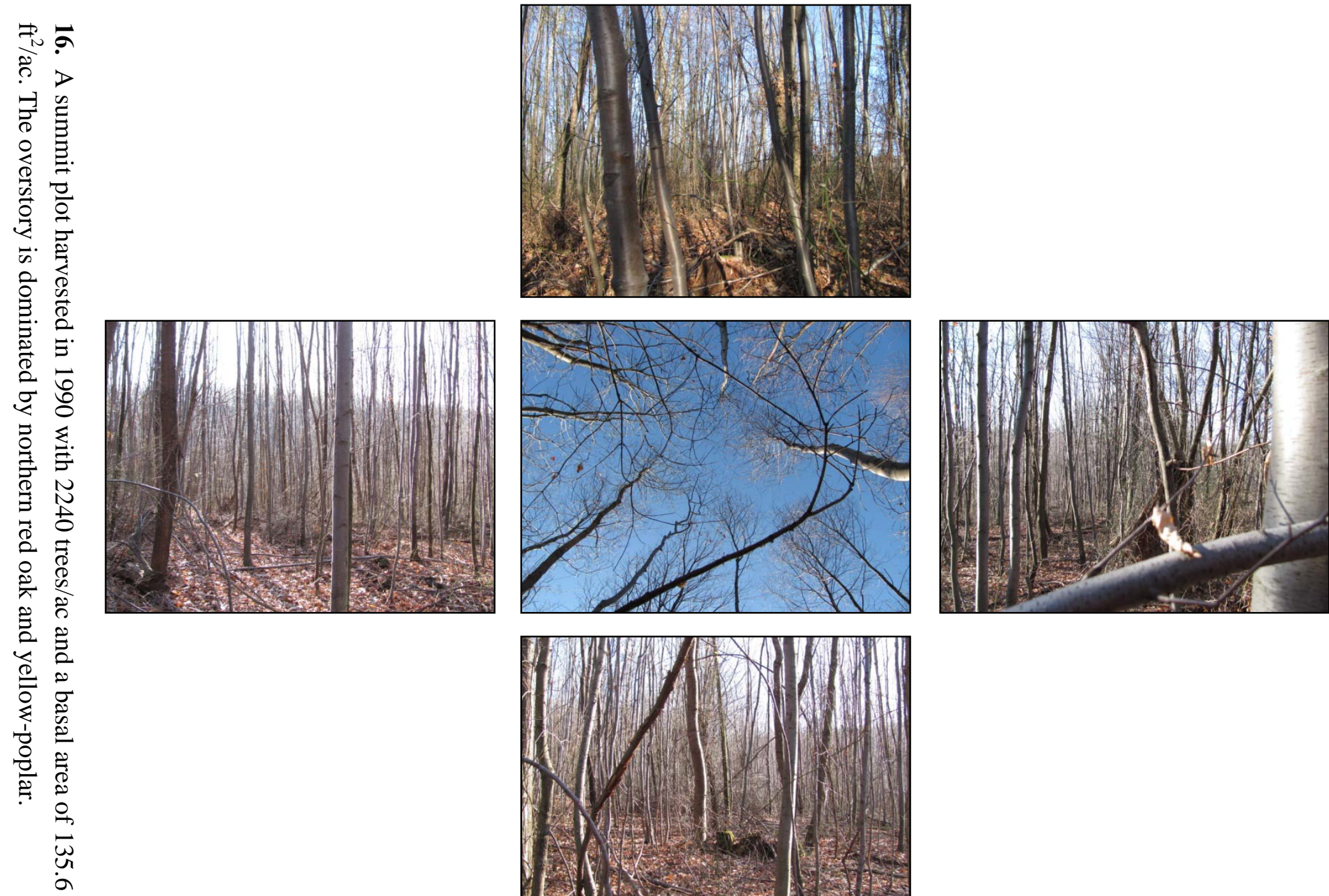

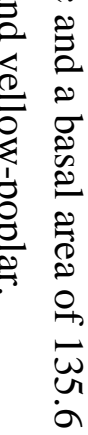

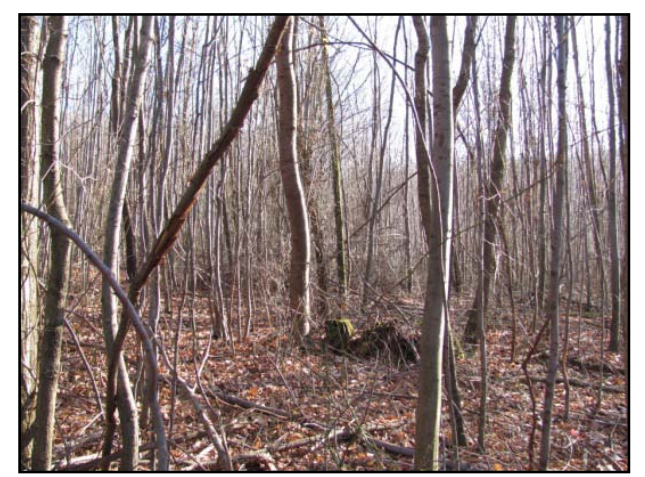



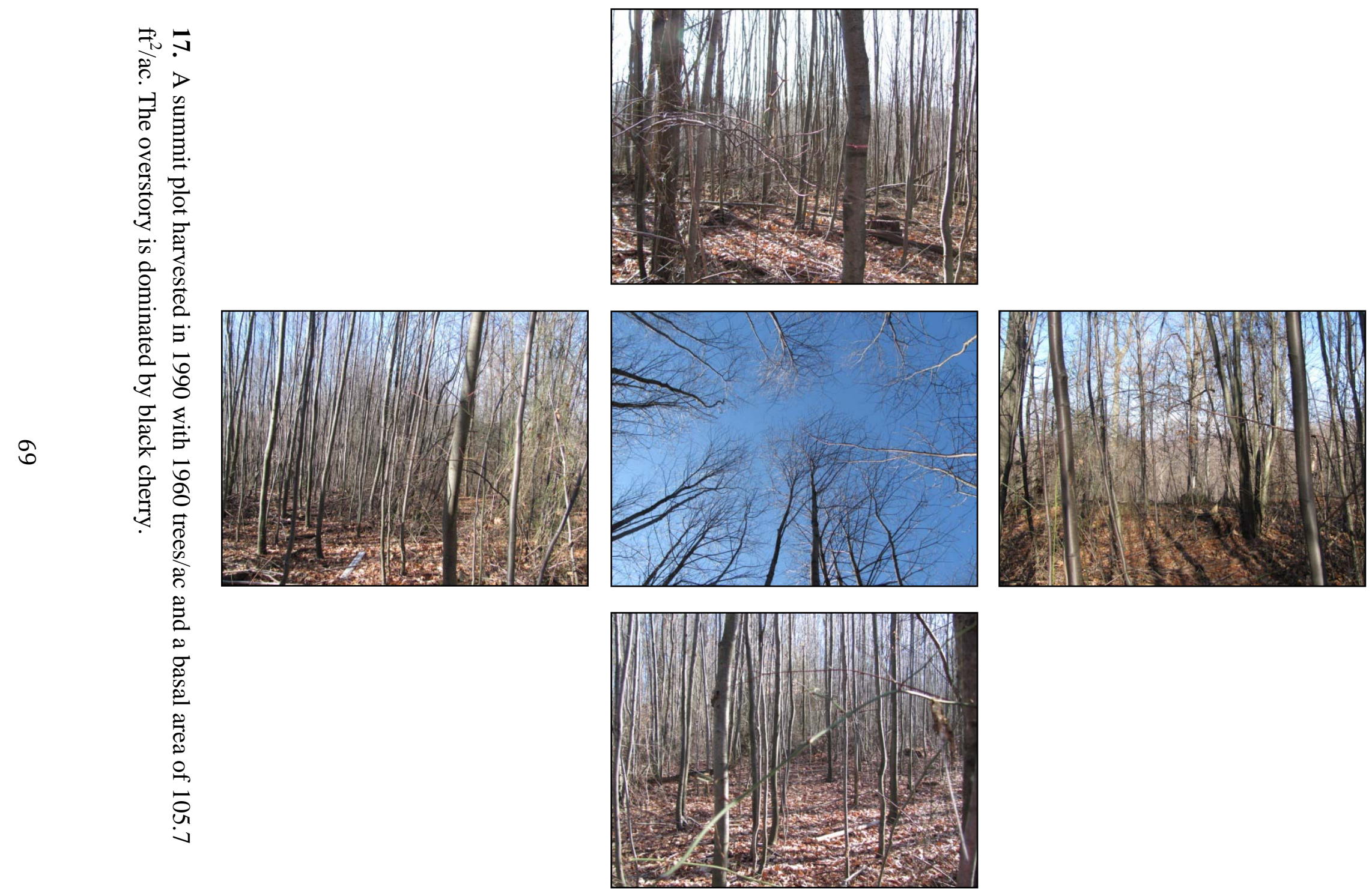

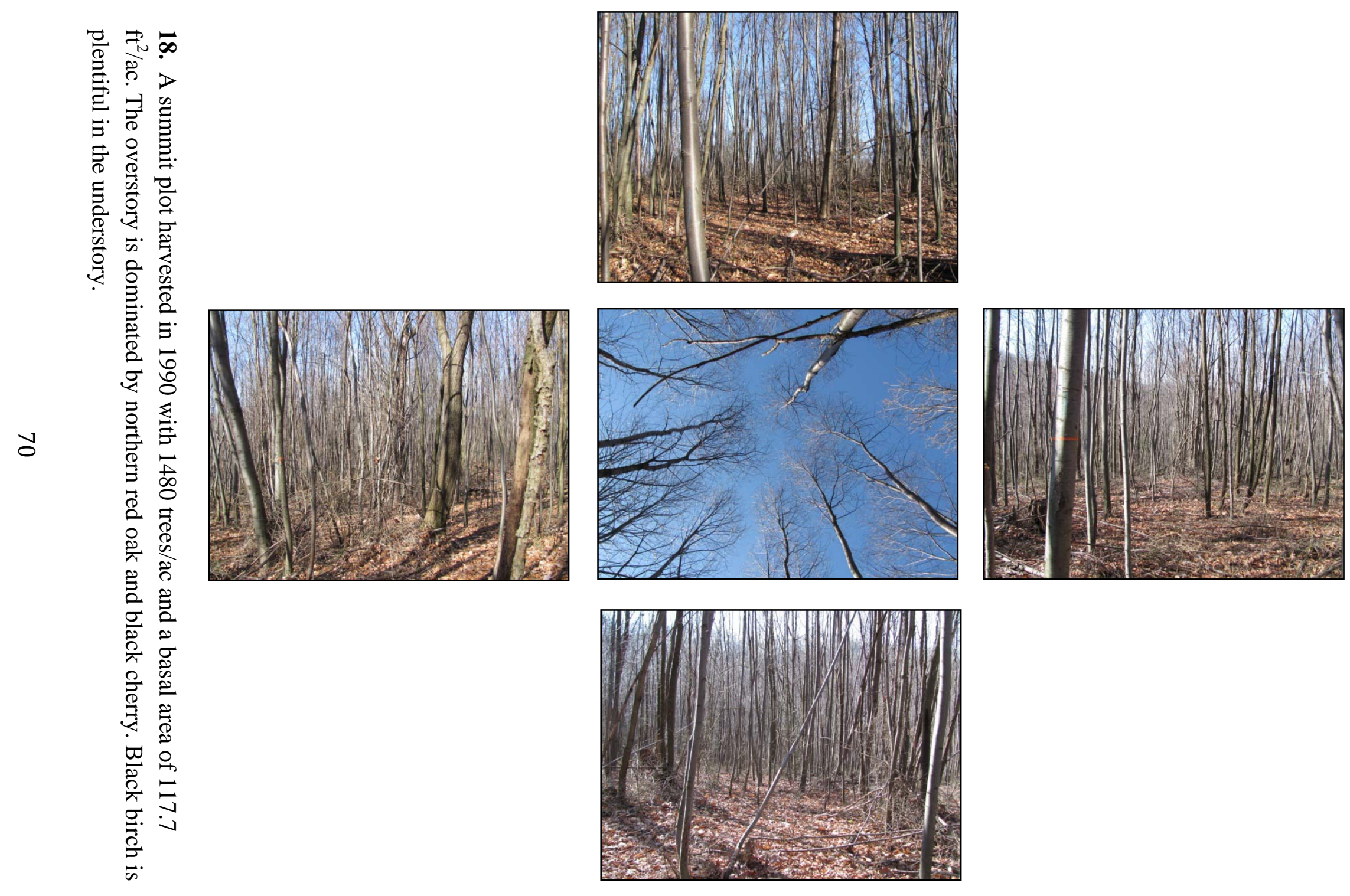


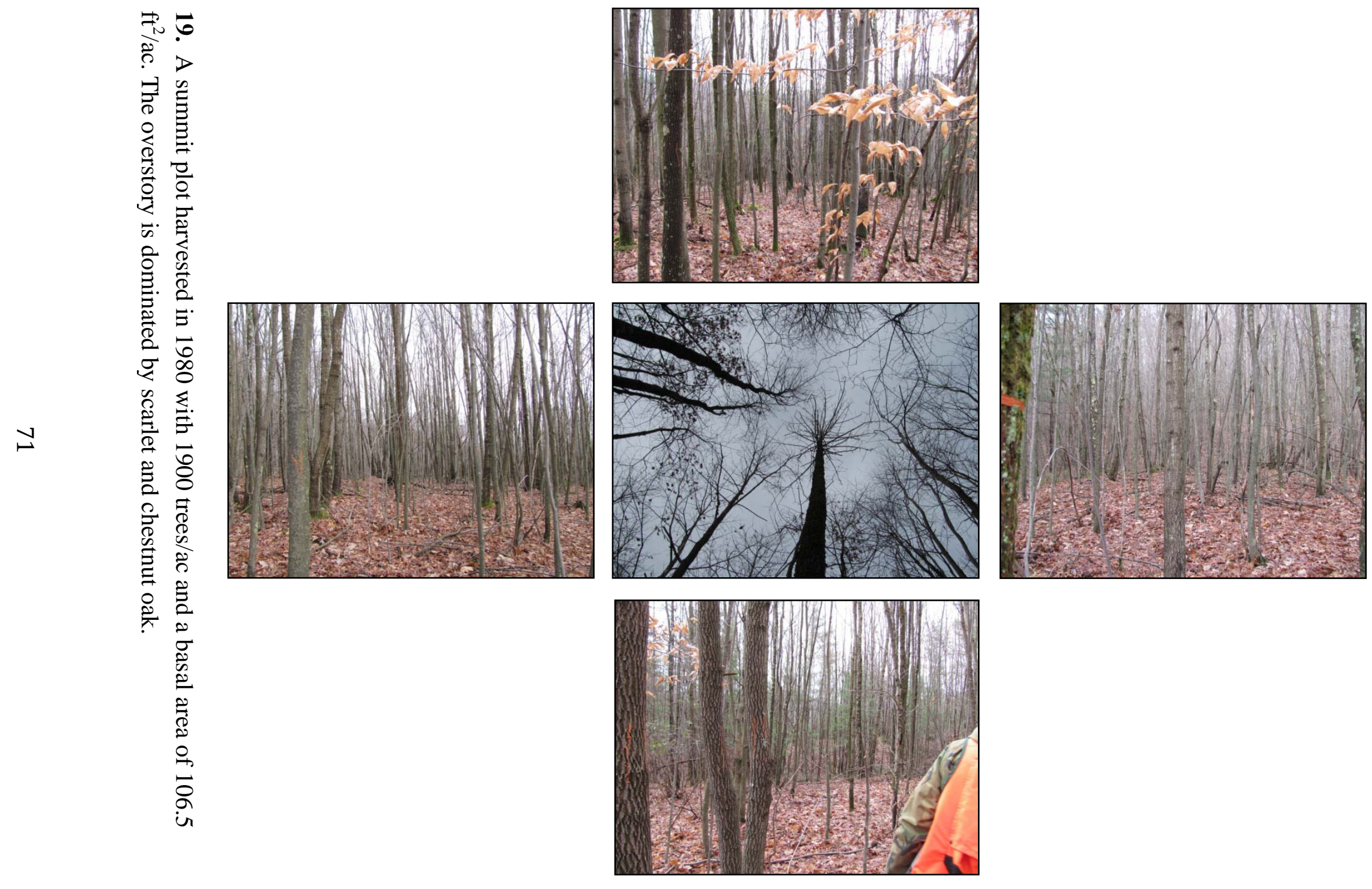



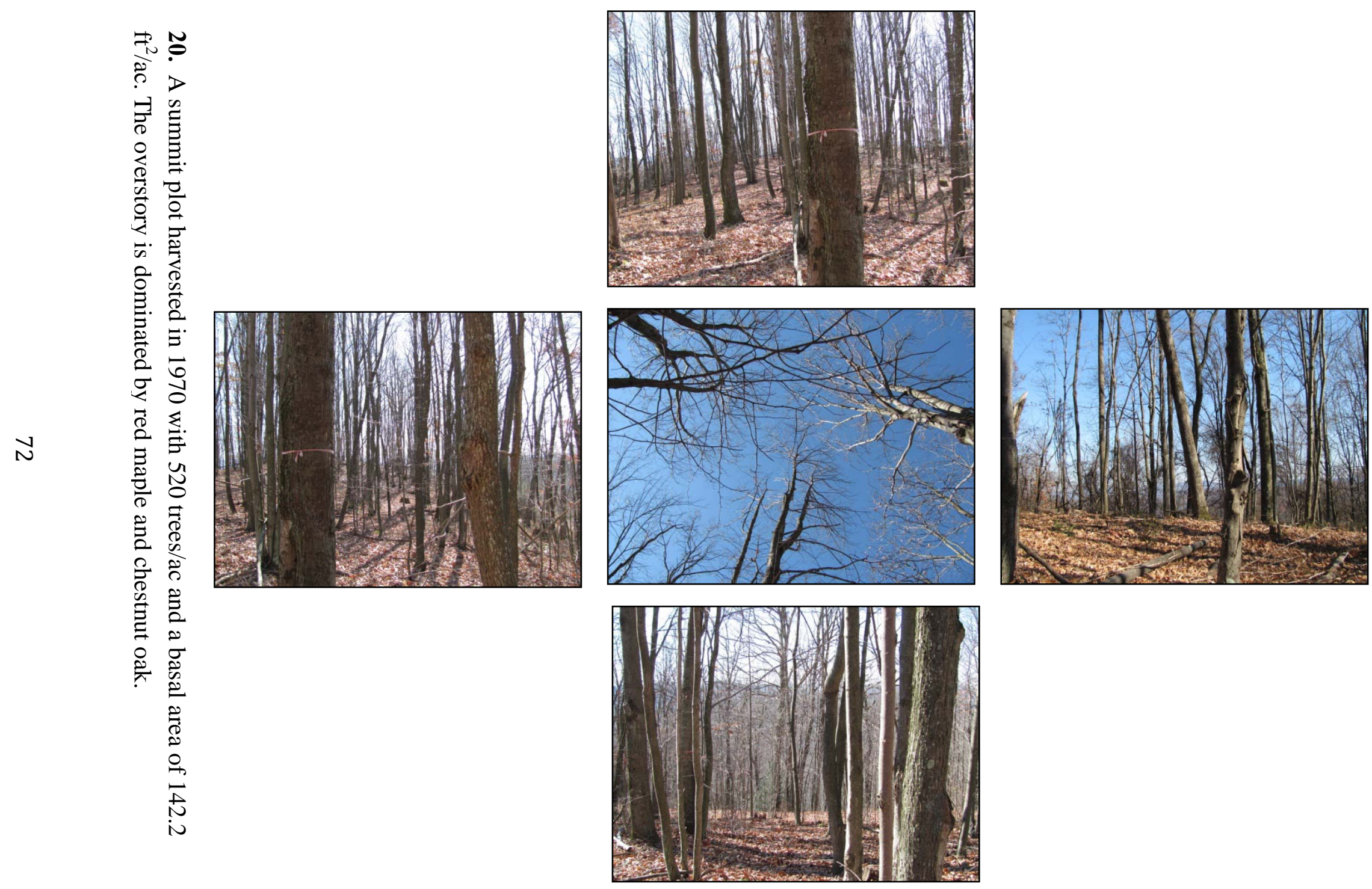

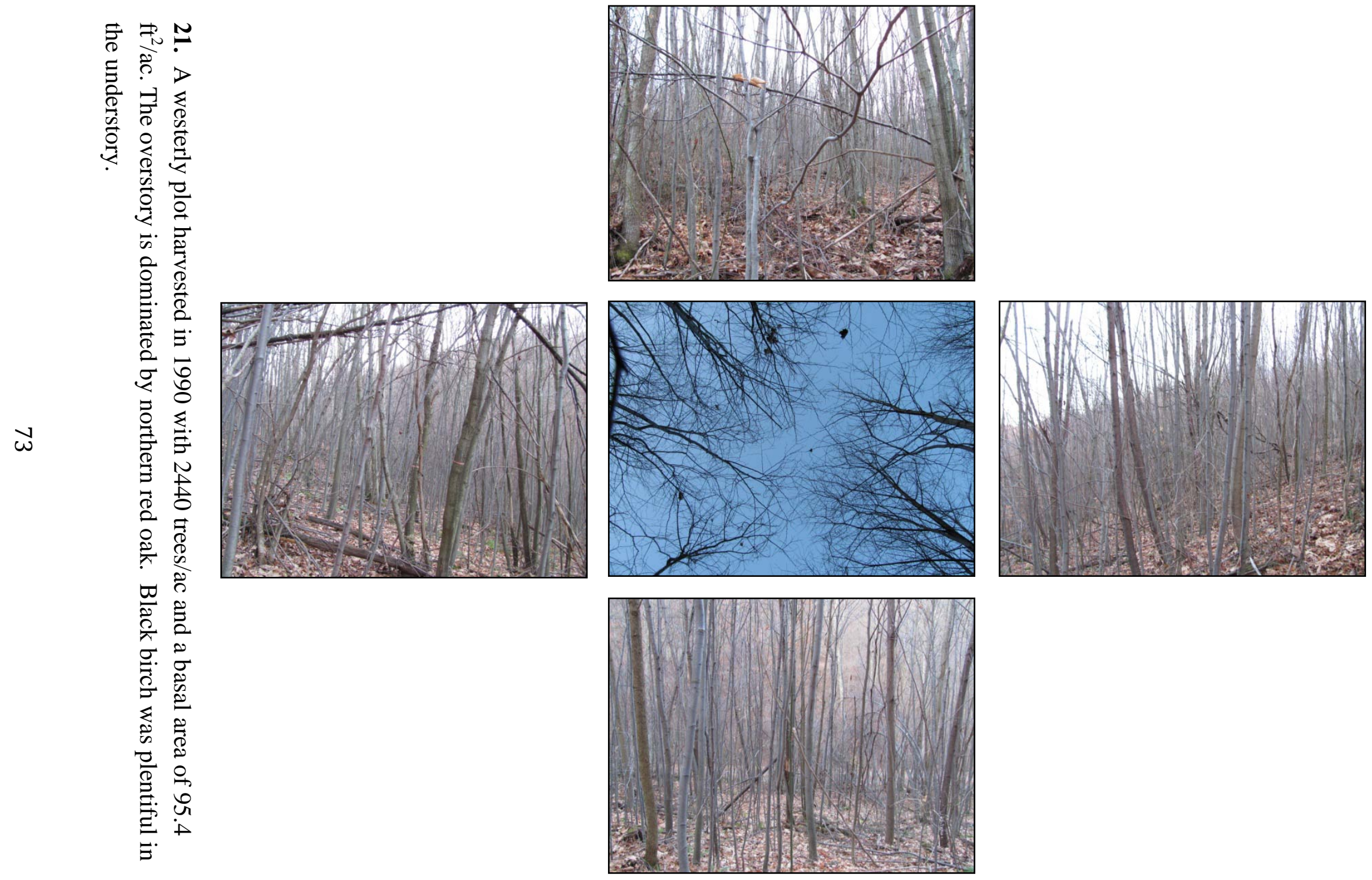

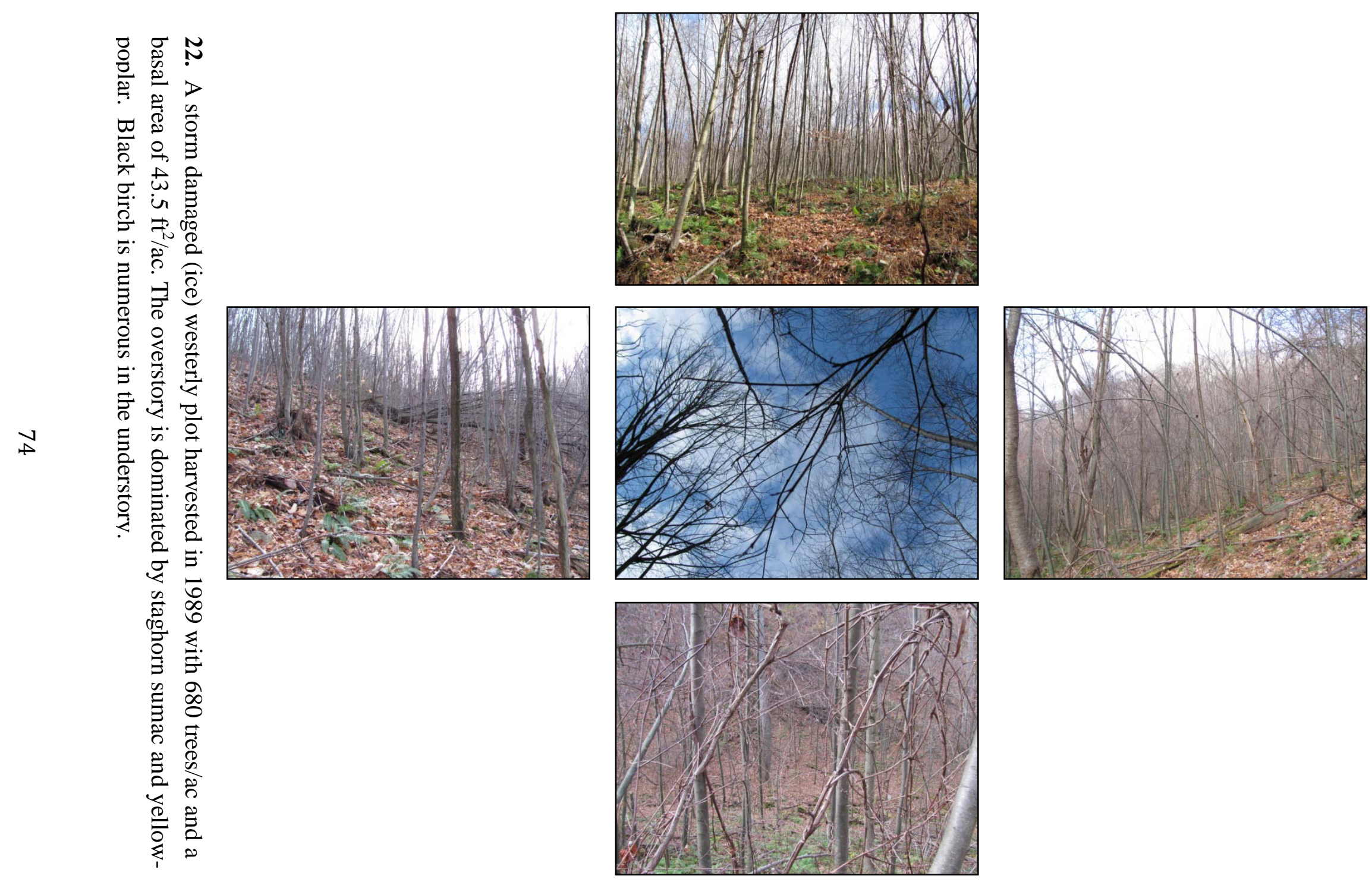


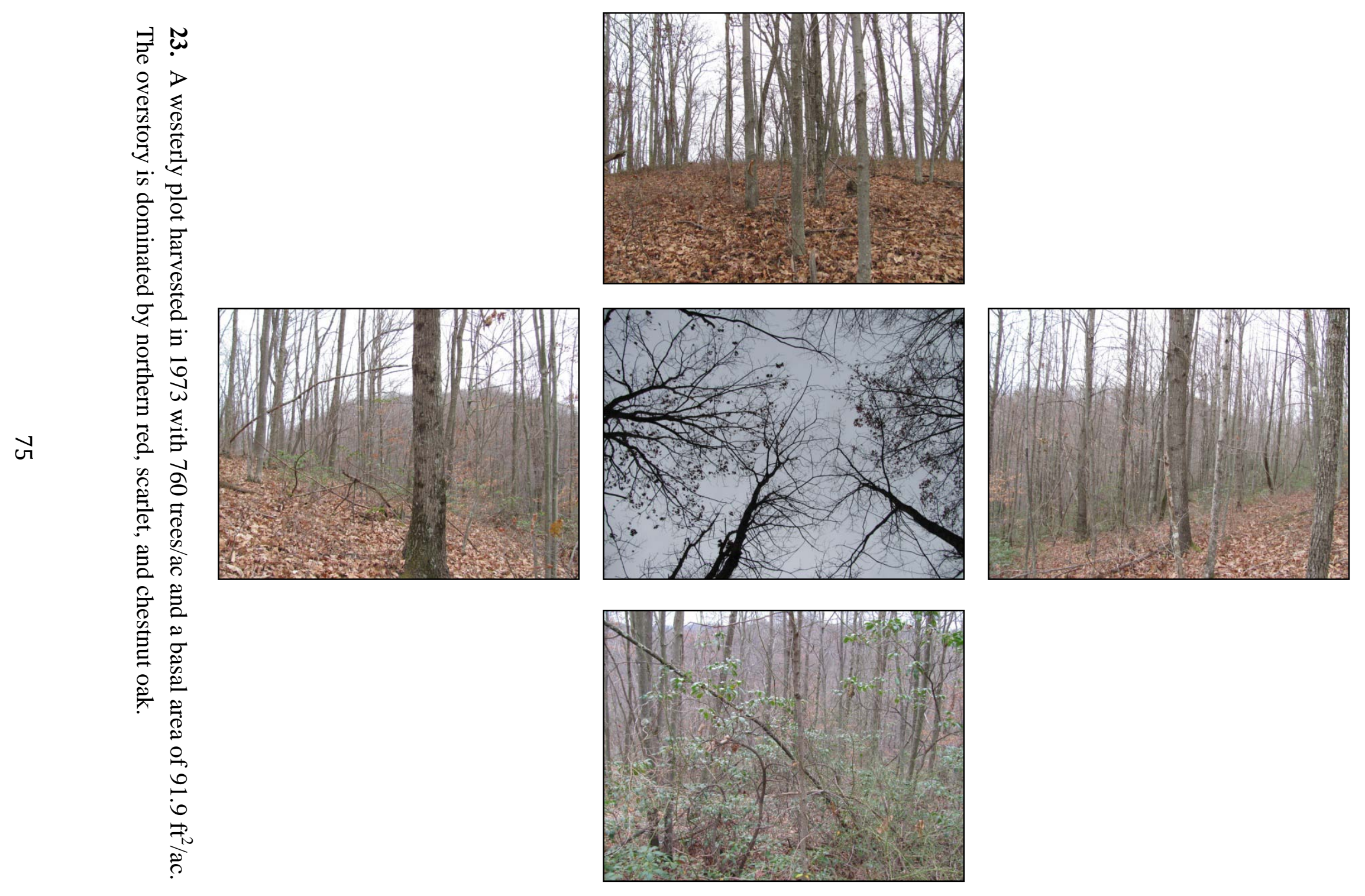



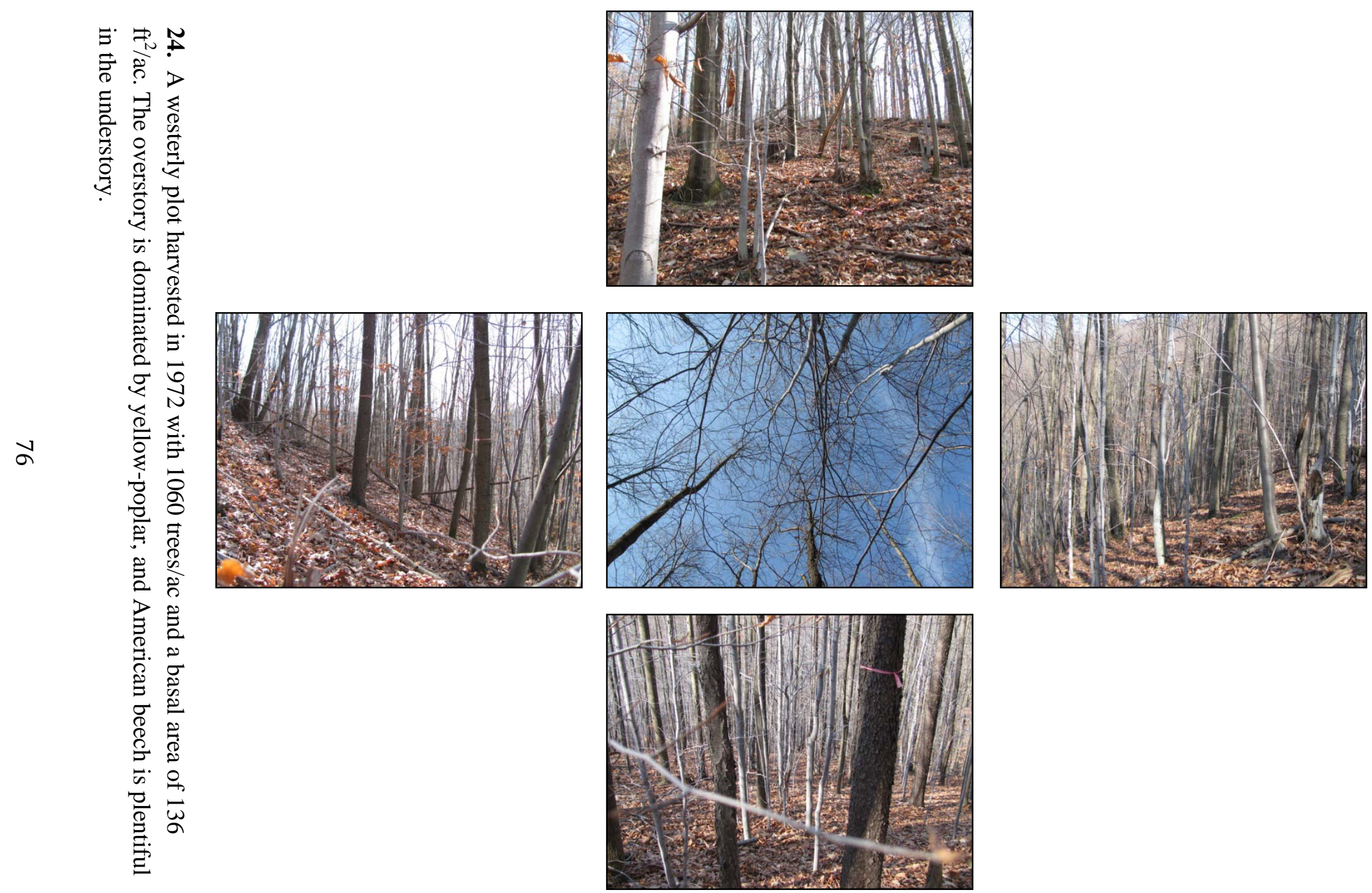

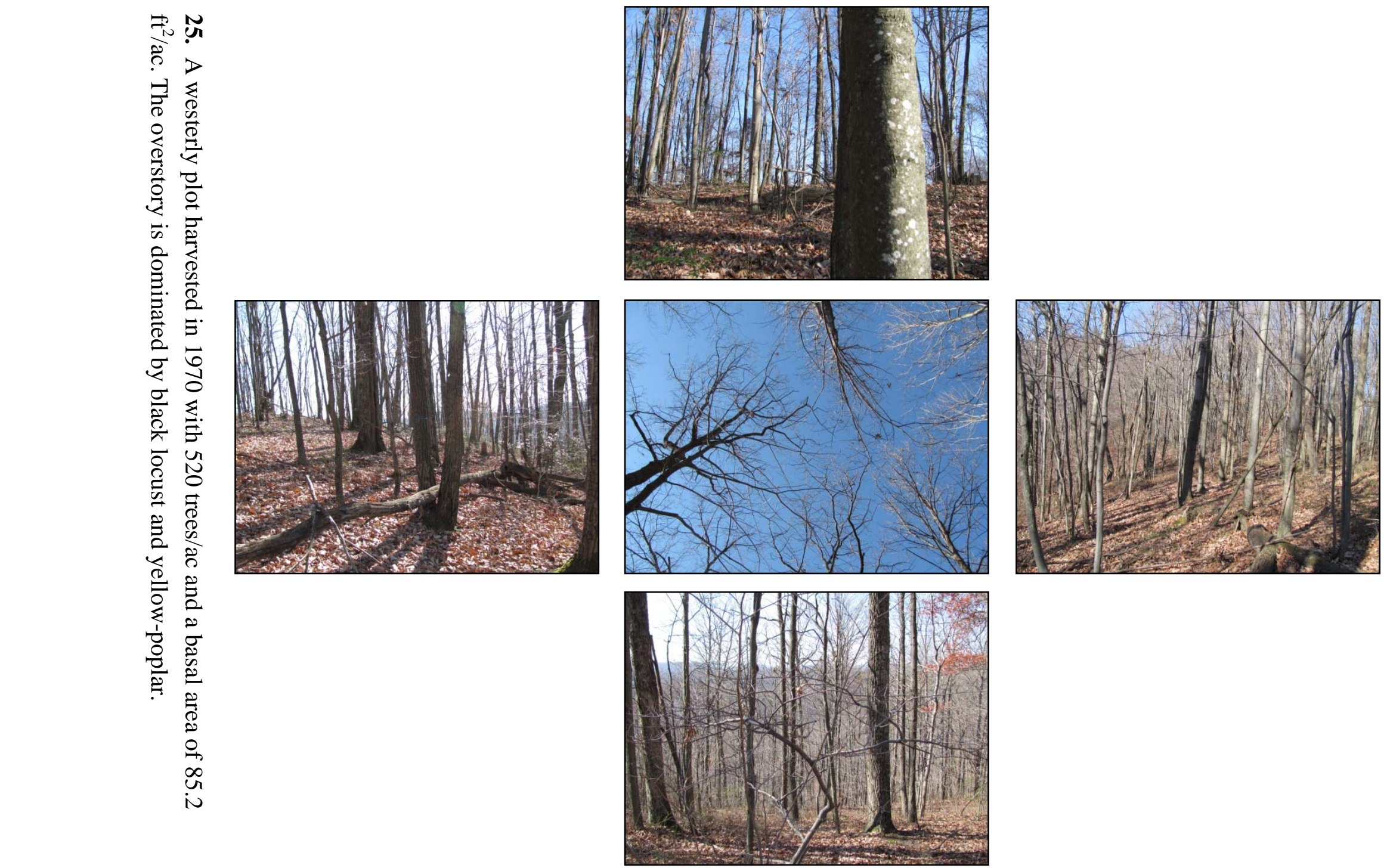

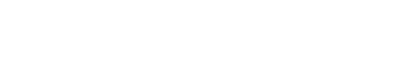

Hagen 